\title{
Novas abordagens da vigilância de doenças transmitidas por alimentos.
}

Ricardo Malaguti

Tese apresentada ao Programa de PósGraduação em Saúde Pública da Faculdade de Saúde Pública da Universidade de São Paulo para obtenção do título de Mestre em Saúde Pública

Área de Concentração: Epidemiologia Orientador: Prof. Dr. Eliseu Alves Waldman 
Autorizo exclusivamente para fins acadêmicos e científicos a reprodução total ou parcial desta dissertação por processos fotocopiadores. Ao usá-la, cite a fonte.

Autor:

Data: 


\section{AGRADECIMENTOS}

Especialmente ao orientador Eliseu Alves Waldman e aos membros da banca Maria Helena Matté e ao Expedito Luna.

Ao Conselho Nacional de Desenvolvimento Científico e Tecnológico (CNPq) pela bolsa concedida. 


\section{Malaguti R. Novas abordagens da vigilância de doenças transmitidas}

por alimentos. São Paulo, 2005. Dissertação (Mestrado) - Faculdade de Saúde Pública, Universidade de São Paulo.

\section{Resumo}

Introdução: As doenças infecciosas tradicionalmente estiveram vinculadas com a miséria e o subdesenvolvimento. Os novos modelos de desenvolvimento, as políticas de industrialização e suas conseqüências, como as mudanças nos hábitos das populaçōes, alteraçōes ambientais urbanas e rurais, migrações e intercâmbio internacional, conferiram maior amplitude e complexidade aos fatores causais de doenças dessa natureza. As doenças transmitidas por alimentos (DTA) representam atualmente fração importante das doenças emergentes, tanto pela contaminação por microorganismos, quanto pela presença de produtos tóxicos, repercutindo em elevada morbi-mortalidade. Objetivos Discutir as caracteristicas, objetivos e vantagens da incorporação no Brasil de um modelo estratégico de vigilância de DTA segundo a experiência da rede nacional de caracterização molecular para vigilância desses agravos em implantação em paises industrializados, a PulseNet. Métodos: Desenvolvimento sistematizado do tema pela pesquisa, análise, seleção e interpretação de conhecimentos disponiveis na literatura constituindo-se de um trabalho de revisão e atualização. Considerações Finais: As DTA constituem importante problema de saúde pública de paises em desenvolvimento e industrializados; sua multicausalidade, intrínseca aos modelos de desenvolvimento econômico, demanda abordagens multidisciplinares no estabelecimento de estratégias para o seu controle e a aplicação experimental de modelos de vigilância, cujos resultados têm-se revelado satisfatórios.

Palavras chave: vigilância, epidemiologia, doenças transmitidas por alimentos; controle. 
Malaguti R. New approaches of foodbome diseases surveillance. São Paulo, 2005. Dissertation (Master) - School of Public Health, University of São Paulo.

\section{Summary}

Introduction: Infectious diseases have traditionally been associated to misery and underdevelopment. New development models, industrialization policies and their consequences, such as the changes in the populations habits, rural and urban environmental changes, migration and international exchange, provide a greater range and complexity to the causal factors of these kinds of diseases. Foodborne diseases currently represent an important fraction of emerging diseases, both through contamination by microorganisms and by the presence of toxic products, resulting in high morbidity and mortality rates. Objectives: Discuss the characteristics, objectives, concepts, feasibility and advantages of the implementation of a new strategic foodborne disease surveillance model in Brazil, namely PulseNet. Methods: Systematic development of the topic through research, analysis, selection and interpretation of available knowledge in the literature, comprising a task of revision and updating. Final Considerations: Foodborne diseases are an important public health problem in developed and developing countries, their multicausalities, intrinsic to economic development models, demand multidisciplinary approaches to the establishment of control strategies and the experimental application of surveillance models, the results of which have proved to be quite satisfactory.

Key words: surveillance, epidemiology, foodborne diseases, control. 


\section{LISTA DE SIGLAS E ABREVIATURAS}

$A B C s$

Active Bacterial Core Surveillance

AlH/DATASUS Morbidade por Internação

APHL

Association of Public Health Laboratories

APPCC

Análise de Perigos e Pontos Críticos de Controle

BPF

Boas Práticas de Fabricação

$C D C$

Centers for Disease Control and Prevention

CETESB

Companhia de Tecnologia e Saneamento Ambiental

COVISA

Coordenadoria de Vigilância em Saúde

CVE

Centro de Vigilância Epidemiológica

DTA

Doença transmitida por alimento

EEB

Encefalopatia espongiforme bovina

EIPS

Emerging Infections Programs

EPI-SUS

Programa de treinamento em epidemiologia aplicada aos serviços do Sistema Único de Saúde

FDA Food and Drug Administration

FSIS

Safety and Inspection Service

IAL

INPPAZ

Instituto Adolfo Lutz

LACEN

Instituto Panamericano de Proteção aos Alimentos e Zoonoses

MDDA

Laboratório Central

MP

Monitorização da Doença Diarréica Aguda

Microbiologia preditiva

NACMCF

National Advisory Committee on Microbiological Criteria for Foods

PCC

Pontos críticos de controle

PFGE

Pulsed Field Gel Eletroforesis

$\mathrm{PH}$

Pontencial hidrogeniônico

SHU

Síndrome hemolítica urêmica

SIM

Sistema de Informação de Mortalidade

SNCD

Sistema de Notificação Compulsória de Doenças

SUVIS

Supervisões de Vigilância em Saúde 


\section{LISTA DE SIGLAS E ABREVIATURAS (continuação)}

SVE-DTA Sistema de Vigilância Epidemiológica das Doenças

Transmitidas por Alimentos

SVS/MS Secretaria de Vigilância em Saúde do Ministério da Saúde

USDA United States Department of Agriculture

vCJD Variante da doença Creutzfeldt-Jakob

Visa Òrgãos nacionais de vigilância sanitária 
INDICE

1. INTRODUÇÃO

1.1. Doenças Transmitidas por Alimentos 1

1.2. Aspectos Etiológicos e Clínicos 4

1.3. Vigilância Epidemiológica 9

1.4. Vigilância de DTA- Estratégias e Abordagens 10

1.4.1. O Perfil de Formação das Equipes 10

1.4.2. Vigilância de Eventos Sentinelas 14

1.4.3. Vigiláncia de Base Laboratorial 16

1.4.4. Vigilância de Base Populacional 17

1.4.5. Investigação Epidemiológica de Campo 19

1.5. Investigação de Agregados de Eventos Adversos à Saúde 19

1.6. Investigação de Surto de DTA 20

1.7. Planejamento Estratégico para o Controle de DTA 23

1.8. Vigilância Sanitária - Fiscalização 28

1.9. Vigilância de Perigos 30

1.10. Análise de Risco 30

1.11. Monitorização como Instrumento de Controle das DTA 33

1.12. Análise de Perigos e Pontos Críticos de Controle - APPCC 35

1.12.1. Aplicação de Elementos da Análise de Risco 39

1.13. Técnicas de Controle Microbiológico 41

1.14. Microbiologia Preditiva 42

1.15. Vigiláncia e Controle das DTA 43

2. OBJETIVOS

2.1. Objetivo geral 44

2.2. Objetivos especificos 44

3. MÉTODOS 45

3.1.1. Delimitação do tema 45 
4.1. PulseNet - Caracteristicas Gerais

4.2. Equipamento Padronizado 50

4.3. Banco de Dados $\quad 50$

4.4. Protocolos Padronizados 52

4.5. Controle de Qualidade 53

4.6. Nomenclatura Padronizada para os Padrões de PFGE 55

4.7. PulseNet em Investigações de Surtos 56

4.8. Vigilância de Surtos de DTA 59

4.9. Pré-requisitos para o Funcionamento Efetivo 61

4.10. Custo Benefício 62

4.11. O Progresso do PulseNet 63

4.12. Foodnet 65

$\begin{array}{ll}\text { 5. CONSIDERAÇÕES FINAIS } & \mathbf{7 3}\end{array}$

$\begin{array}{ll}\text { 6. REFERENCIAS } & 87\end{array}$

$\begin{array}{ll}\text { 7. ANEXOS } & 101\end{array}$

- Anexo 1 - Ficha de Investigação de Surto de DTA

- Anexo 2 - Resumo das informações Obtidas dos Questionários de Investigação do Surto

- Anexo 3 - Ficha de Investigação de Surto de DTA II

- Anexo 4 - Parâmetros Microbiológicos e Técnicas de Identificação

- Anexo 5 - Padrões de Referência Microbiológica para alguns Alimentos Submetidos à Investigação Microbiológica

- Anexo 6 - Aspectos Clínicos e Epidemiológicos Relacionados aos Principais Agentes Envolvidos nas DTA 


\section{INTRODUÇÃO}

\subsection{Doenças Transmitidas por Alimentos}

As doenças infecciosas tradicionalmente vinculavam-se a miséria e ao subdesenvolvimento. Os modelos de desenvolvimento, as políticas de industrialização, alterações ambientais urbanas e rurais, migrações, intercâmbio internacional além dos processos de adaptação e mutação que ocorre na população microbiana, conferiram maior amplitude e complexidade aos fatores associados ao comportamento das doenças infecciosas (ALTEKRUSE et al.. 1997; TAORMINA et al. 1999; HUGHES 2001; TAUXE 2002a; FIDLER 2003; WOTEKI e KINEMAN 2003).

De certa forma, como reflexo desse processo, temos recentemente a ampla aplicação do conceito de doenças infecciosas emergentes, entendidas como aquelas já existentes ou recentemente identificadas e que aumentaram sua incidência e ampliaram sua distribuição geográfica (MORSE 1996; MORSE e HUGHES 1996; PINNER et al. 2003)

O comportamento das doenças transmitidas por alimentos (DTA) tem apresentado acentuadas modificações decorrentes do aumento da vulnerabilidade da população humana decorrente de mudanças no estilo de vida; como modificações nos hábitos de preparo e consumo de alimentos, pelo expressivo aumento da freqüência de refeições feitas em restaurantes comerciais ou de empresas, ingerindo alimentos preparados em cozinhas industriais, ou mesmo pela utilização de alimentos semiprontos. Tais 
mudanças devem-se, principalmente, às condições de vida em grandes cidades e à inserção da mulher no mercado de trabalho (MOTARJEMI e KAFERSTEIN 1999; MENG e DOYLE 2002).

Além dos fatores citados relativos à suscetibilidade, o crescimento e envelhecimento populacional, a imunodepressão, a desnutrição, a gravidez; carência habitacional, a urbanização sem o suprimento adequado de água e infra-estrutura, podem predispor os individuos às DTA (MOORRIS e POTTER 1997, SMITH 1999; MOTARJEMI e KAFERSTEIN 1999).

Como veículos dessas doenças, a importância dos alimentos acentuou-se pela extensão da cadeia de produção e o estreitamento das relações econômicas e comerciais, favorecendo a emergência de novos microrganismos e a disseminação dos existentes. $\mathrm{O}$ aumento significativo da ocorrência de Salmonella Enteritidis no estado de São Paulo, parece estar associado ao intercâmbio comercial de matrizes de aves com países da Europa, o que pode ter facilitado a introdução e disseminação do fagotipo PT-4, a partir de 1993, no Brasil (BUCHANAN 1997; PERESI et al. 1998, MOTARJEMI E KAFERSTEIN 1999).

O desenvolvimento de novas tecnologias destinadas ao aumento da produtividade e redução de custos ampliou o número de pontos críticos da cadeia produtiva, aumentando as oportunidades de contaminação de alimentos por agentes infecciosos tornando por decorrência, mais freqüentes os surtos epidêmicos de DTA (MORSE 1996; MOTARJEMI e KAFERSTEIN 1999; KIMURA et al. 2004). 
Tradicionalmente os surtos epidêmicos de DTA estavam associados a alimentos de origem animal, no entanto, recentemente as frutas, vegetais e outros produtos de elevada acidez tornaram-se veículos importantes de agentes infecciosos, induzindo a comunidade científica a reconsiderar a natureza e extensão das DTA (TAUXE 1997; VAN DE VENTER 2000; BUZBY 2002; WOTEKI E KINEMAN 2003; DeWAAL 2003).

Agravando o quadro, observa-se a inadequação da educação e treinamento de profissionais em segurança alimentar; fragilidade na investigação e vigilância de DTA e monitoramento de contaminantes, incapacidade em avaliar o impacto de intervenções e falta de conhecimento das autoridades de saúde pública da magnitude e conseqüências das DTA (MOTARJEMI e KAFERSTEIN 1999).

Segundo MOTARJEMI e KAFERSTEIN (1999), qualquer pais pode ser afetado pelas DTA. Estudo realizado nos EUA por MEAD et al. (1999), revelou 38 milhões de casos/ano e segundo WETHINGTON e BARTLETT (2004) e DeWAAL (2003), as DTA estiveram envolvidas em 76 milhōes de casos de gastrenterites e 5.000 óbitos/ano nesse país.

O Instituto Panamericano de Proteção aos Alimentos e Zoonoses (INPPAZ) notificou cerca de 180 surtos de DTA no Brasil em 2000, frutos de uma estimativa imprecisa e da subnotificação. No Estado de São Paulo, em 2001, foram notificados cerca de 140 mil casos de diarréias, destes, quase 50 mil casos atribuidos a surtos de DTA. No entanto, estima-se a ocorrência de um milhão de casos de diarréias (CVE 2002). 
Os dados disponiveis sobre o assunto, sugerem que as DTA são fração importante das doenças emergentes pela contaminação por microrganismos e presença de produtos tóxicos, repercutindo em elevada morbi-mortalidade, refletindo na saúde e economia (KAFERSTEIN 1997; KAFERSTEIN 2003).

\subsection{Aspectos Etiológicos e Clínicos}

O espectro de patógenos associados às DTA inclui bactérias entéricas, aeróbias e anaeróbias, vírus, fungos, parasitas, dinoflagelados marinhos, bactérias que produzem biotoxinas em peixes e ostras e os prions auto indutores de encefalopatias transmissiveis (doença de CreutzfeldtJacob). Alguns microrganismos como a Shigella spp ou os vírus Norwalklike, têm o homem como reservatório, enquanto muitos outros têm em animais ou no ambiente o seu reservatório; para esses, o homem é um hospedeiro acidental (MEAD et al. 1999; TAUXE 2002a).

Dentre os agentes que têm se destacado e possivelmente assumirão grande importância na etiologia das DTA podemos apontar: Escherichia coli Q157:H7, Listeria monocytogenes, Salmonella spp Campylobacter jejuni e Yersinia enterocolitica, Cryptosporidium e Cyclospora, e o vírus Norwalk-like (WOTEKI e KINEMAN 2003; SCHLUNDT 2002).

Estudo realizado por MEAD et al. (1999), revelou que os microrganismos e parasitas citados estão envolvidos em mais de $90 \%$ dos óbitos relacionados ao consumo de alimentos nos EUA e, em relação às 
hospitalizações, $60 \%$ foram atribuídas às DTA causadas por bactérias, seguidas pelas de etiologia viral $(34 \%)$ e parasitária $(5 \%)$.

Segundo WOTEKI e KINEMAN (2003), agentes desconhecidos, ou seja, organismos que ainda não foram identificados ou não são detectáveis pelas técnicas disponiveis, envolvem-se em aproximadamente $81 \%$ das DTA e $64 \%$ dos óbitos relacionados a estas doenças nos EUA FRENZEN (2004) estima que estes agentes causem 3.400 óbitos/ano nesse país considerando os casos de gastrenterite; em relação aos 2.800 surtos de DTA registrados de 1993 a 1997, mais de dois terços foram atribuídos a causas indeterminadas.

Dois tipos de emergência relacionam-se com microrganismos patogênicos de origem alimentar. No primeiro tipo, um microrganismo não identificado como uma ameaça de saúde pública começa a causar uma doença e, no outro, considerado uma reemergência, um agente conhecido atua por novos tipos de infecção, novos alimentos ou em novas localizações geográficas (BUCHANAN 1997; TAUXE 2002a; KOOPMANS et al. 2003).

Alguns microrganismos como a Escherichia coli 0157:H7, são provavelmente genuinamente novos, possivelmente com envolvimento nas DTA relativamente recente. Outros, como o virus Nonwalk-like e Vibrio vulnificus, foram identificados recentemente, embora seja provável que se envolvam com as DTA por séculos. Outros como o Campylobacter jejuni e Listeria monocytogenes, são conhecidos como patogênicos há várias décadas, mas não como de origem alimentar - esta é a importância da 
elucidação da rota de transmissão ocorrida recentemente (TAUXE 2002a; KOOPMANS et al. 2003).

Alguns agentes associados às DTA apresentam virulência não observada no passado, podendo causar doenças crônicas. A enfermidade neurológica conhecida como Síndrome de Guillain-Barré pode ser uma condição crônica decorrente de infecções por Campylobacter atingindo preferencialmente idosos, esta reação auto imune pode causar paralisia e os custos médicos, perdas com produtividade e mortes prematuras atingem 1,3 bilhões de dólares/ano nos EUA (WOTEKI e KINEMAN 2003; LEGNANI 2004).

O aumento da freqüência da resistência a antimicrobianos é outra tendência entre as bactérias patogênicas veiculadas por alimentos. Para aquelas com reservatórios primários em humanos, tais como Shigella spp. e S. Typhi, a emergência da resistência está relacionada ao uso de antibióticos em populações humanas objetivando o tratamento da doença. No entanto, para os agentes cujos reservatórios primários são animais, a principal causa do aumento da resistência é o uso indiscriminado de antibióticos em rações para promoção do crescimento de animais, contribuindo para a seleção e disseminação de cepas resistentes (TAUXE 2002a; WOTEKI e KINEMAN 2003; IOVINE e BLASER 2004).

Dentre as cepas multiresistentes de bactérias destacam-se Samonella sp. (Salmonella Typhimurium DT 104), Streptococcus pneumoniae, Enterococcus sp., Klebsiella pneumoniae e Campylobacter jejuni; fenômeno semelhante tem sido assinalado entre fungos como a Candida albicans, 
Aspergillus sp. e Cryptococcus neoformans (WOTEKI e KINEMAN 2003; KAFERSTEIN 2003; LEGNANI 2004).

Este amplo espectro de agentes infecciosos causa uma série de sindromes no hospedeiro humano, a maioria com um componente gastrointestinal de vômito e diarréia. Os invasivos podem produzir outras síndromes clínicas, e as toxinas veiculadas por alimentos podem afetar muitos sistemas do organismo humano. Quando abordamos as DTA devemos considerar um amplo espectro de doenças e patógenos (TAUXE 2002a).

Dentre as DTA devemos citar também o botulismo que resulta da ingestão de alimentos contendo toxina pré-formada de Clostridium botulinum e caracteriza-se por alterações da visão, diplopia, disfagia e fraqueza muscular descendente (CHANG 2004).

Entre as DTA associadas a $E$. coli temos a sindrome Hemolitica Urêmica (SHU) causada pela $E$. Coli $0157: H 7$, bactéria identificada nos anos 80; suas manifestaçōes clínicas principais são: anemia aguda, insuficiência renal e baixa contagem de plaquetas (CDC 2004a, BRASIL 2004c). Temos ainda as infecções pela $E$. coli enterohemorrágica caracterizada por diarréia sanguinolenta intensa (BRASIL 2004C).

Há indícios de que a doença de Johne em animais, cujo agente etiológico é a subespécie paratuberculosis (Map) de Mycobacterium avium, esteja associada à doença de Crohn em humanos, caracterizada pela inflamação crônica de uma ou mais partes do tubo digestivo, sendo o leite 
(inclusive pasteurizado) e outros alimentos, possíveis veículos de transmissão (KAFERSTEIN 2003).

A glomérulo nefrite aguda é outro exemplo de doença que pode ser transmitida por alimento, como ilustra o surto de nefrite pós-estreptocócica em Nova Serrana, Brasil, (associados ao consumo de queijo não pasteurizado contaminado pelo Streptococcus equi, subespécie zooepidemicus). Esses casos caracterizam-se pela presença de febre, cefaléia, mialgia e adenopatia cervical, sendo que as manifestações renais, glomerulonefrite com oligúria, hematúria, edema generalizado e hipertensão ocorrem após 7 a 10 dias (BALTER et al. 2000).

A Encefalopatia Espongiforme Bovina - EEB, também conhecida como "doença da vaca louca", associa-se a um agente recentemente identificado, o príon, capaz de provocar um quadro degenerativo crônico e transmissivel do sistema nervoso central de bovinos. A doença pode ocorrer em humanos, caracterizada por sintomas iniciais psiquiátricos, alterações neurológicas tardias, ataxia, demência e mioclonias tardias e existem fortes evidências de que a nova variante da doença Creutzfeldt-Jakob (vCJD) resulta do consumo de produtos de bovinos infectados (CONFERENCE REPORT 2004).

Apesar das DTA gerarem impacto importante na saúde pela sua magnitude, pouca consideração tem sido-lhe atribuida por seus sintomas serem geralmente moderados e autolimitados, porém, infecções como a SHU associada a E. Coli O157:H7, tem letalidade de 5 a 10\% (CVE 2002; BUZBY 2002; LEGNANI 2004; CHANG et al. 2004). 


\subsection{Vigilância Epidemiológica}

Segundo LANGMUIR (1963), a vigilância abrange a observação contínua da distribuição e tendência da incidência de uma doença pela coleta sistemática, consolidação e avaliação dos relatórios de morbimortalidade e a interpretação e divulgação regular dos dados para aqueles que contribuíram e demandam-nos, não incorporando atividades de controle, de incumbência das autoridades de saúde.

O Sistema Nacional de Vigilância Epidemiológica define em seu texto legal (lei 8.080/90) como um conjunto de ações para o conhecimento, a detecção ou prevenção de mudanças nos fatores determinantes da saúde individual ou coletiva, recomendando as medidas de prevenção e controle das doenças ou agravos.

A vigilância epidemiológica fornece orientação técnica para os profissionais de saúde para as ações de controle de doenças e agravos, disponibilizando informações pela utilização de metodologia simples, sobre ocorrência e fatores condicionantes, numa área geográfica ou população definida (WALDMAN 1991).

Dessa forma, ao verificar aumento na freqüência da doença ou identificar agregados de eventos adversos à saúde, a vigilância desencadeia investigação epidemiológica indutora da implementação de medidas de controle, identifica áreas passíveis de pesquisa aplicada e demonstra o controle, proporcionando segurança pública (TAUXE 2002b). 
A vigilância passiva possui limitações que conduzem à implementação de técnicas de vigilância ativa pela busca e solicitação regular de informaçōes dos agravos à saúde e, a vigilância ativa pelos sistemas sentinelas produz estimativas confiáveis da incidência de doenças (VOGT et al. 1983; SCHLUNDT 2002).

Portanto, a vigilância de DTA estima impacto, monitora tendências, identifica prioridades, politicas de controle e prevenção, detecta surtos e avalia estratégias; contudo, pode ser prejudicada pelo sub-registro, casos moderados geralmente não são detectados; patógenos transmitidos por alimentos transmitem-se pela água ou pessoa-pessoa e proporção importante é causada por patógenos não identificados (MEAD et al. 1999, SCHLUNDT 2002; TAUXE 2002a).

\subsection{Vigilância de DTA - Estratégias e Abordagens}

\subsubsection{O Perfil de Formação das Equipes - Capacitação e Treinamento}

A formação, capacitação e treinamento de recursos humanos para atuarem na vigilância e controle das DTA são de relevância em saúdẹe pública, pois ainda não possuímos nümero restrito de profissionais especificamente preparados para atuar na área. É de interesse que os epidemiologistas que atuam nesta área, nas três esferas de governo, estejam habilitados a desenvolver sistemas de vigilância para DTA, a identificar surtos e desenvolver investigações conclusivas, inclusive 
identificando novos agentes ou grupos ou fatores de risco (PETERSEN et al. 2000).

O Brasil tem desenvolvido experiências interessantes na área de capacitação e treinamento em vigilância epidemiológica, inclusive de DTA, uma delas é o programa de treinamento em epidemiologia aplicada aos serviços do Sistema Único de Saúde (SUS), o EPI-SUS; implementado numa colaboração entre o Centers for Disease Control and Prevention $(C D C)$ e a Secretaria de Vigilância em Saúde do Ministério da Saúde (SVS/MS), visando formar epidemiologistas de campo, fortalecendo o conhecimento e as habilidades práticas em epidemiologia para responder às necessidades em saúde pública do Brasil (BRASIL 2004a).

O Projeto Intersetorial de Vigilância das DTA e Água no estado de São Paulo proporciona estágios aos profissionais de saúde em sistemas de vigilância de outros paises, aprimoramento e intercâmbios técnico, assessorias em investigações de surtos de DTA, além de proporcionar curso de especialização em DTA, mediante convênio com a Faculdade de Saúde Pública da Universidade de São Paulo (CVE 2002)

Clínicos, epidemiologistas, profissionais de saúde, veterinários, especialistas em higiene de alimentos, inspetores de saúde, profissionais de saúde ambiental, enfermeiros, microbiologistas e químicos, podem integrar a equipe de vigilância de DTA, variando segundo os objetivos e necessidades. Essa deve ser submetida a treinamento e capacitação contínuos para o domínio e conhecimento da magnitude e importância das DTA, dos objetivos do sistema de vigilância, das atividades e procedimentos no estudo de 
surtos além da interpretação dos resultados dos exames (OPAS/INPPAZ 2001).

$\ddot{E}$ interessante ainda pontuar algumas experiências internacionais e seus respectivos resultados como forma aperfeiçoar e adaptar as experiências nacionais no processo de capacitação e treinamento.

Os EUA têm desenvolvido programas para aumentar o número de epidemiologistas treinados enfatizando a necessidade de oportunidades de educação continuada para os profissionais e o incentivo destes, pelas escolas de saúde pública, a ocuparem cargos nos departamentos de saúde. Porém, devido à escassez orçamentária, recursos precisam ser identificados (CDC 2003; PINNER et al. 2003).

Os programas para as doenças infecciosas emergentes (Emerging Infections Programs - EIPs) envolvem treinamento, contemplam projetos voltados às DTA, oferecem suporte à vigilância e apóiam a pesquisa. Dependem da colaboração entre as agências de saúde pública e as instituições clínicas e acadêmicas para conduzir pesquisa laboratorial e epidemiológica aplicada, implementar e avaliar projetos de prevenção e intervenção, prover capacitação, medir o impacto das DTA e desenvolver método laboratorial e epidemiológico para a vigilância de síndromes. Dentre seus projetos voltados para o problema das DTA, a FoodNet gera estimativas de incidência e subsidia estudos de fatores de risco, espectro de doenças, estratégias de prevenção, estimativa da ocorrência de doença diarréica e o grau de subregistro (PINNER et al. 2003; PATRICK et al. 2004). 
Com o desenvolvimento de uma rede internacional de EIP (IEIP) com Ministérios da Saúde e parcerias, poderão surgir oportunidades de treinamento para o Brasil, a exemplo do EPI-SUS (PINNER et al. 2003).

Na Europa temos também experiências interessantes na área de treinamento em epidemiologia de campo voltada à vigilância e controle das DTA. A Alemanha, por exemplo, tem desenvolvido uma programação de treinamentos focalizando diversos instrumentos de interesse à vigilância: investigação de surtos e pesquisas complementares, sistemas de vigilância utilizando a transmissão eletrônica de dados, vigilância sentinela para a $E$. Coli enterohemorrágica e $S H U$, avaliação do sistema sentinela de base laboratorial para infecçōes virais e monitoramento de surtos. Tais treinamentos de curto prazo permitiram a formação de equipes treinadas na área de vigilância e controle de DTA. O custo anual estimado desse programa foi de cerca de U\$250.000 (PETERSEN et al. 2000).

O sucesso dessas experiências está vinculado, em boa medida, à experiência da equipe responsável pelo treinamento, sendo que a assessoria externa, geralmente oferecida por consultores internacionais tem sido fator importante para os bons resultados das iniciativas desenvolvidas com essa finalidade em diferentes países e regiōes do globo (PETERSEN et al. 2000; CDC 2003). 


\subsubsection{Vigilância de Eventos Sentinelas}

Segundo WALDMAN e ROSA (1998), o termo evento sentinela pode ser utilizado para eventos que possam servir de alerta a profissionais de saúde a respeito da possivel ocorrência de agravos passiveis de prevenção, incapacidades ou óbitos possivelmente associados a má qualidade de intervenções de caráter preventivo ou terapêutico, que devem ser aprimorados.

BORGDORFF e MOTARJEMI (1997) ressaltam que a vigilância de eventos sentinelas é realizada pela análise de dados de testes laboratoriais e de exames clínicos e sua abrangência é definida em função da organização dos serviços de saúde, assim, o número de casos novos de eventos sob vigilância pode ser expresso em taxas de incidência.

Segundo HEFFERNAN et al. (2004), a monitorizaçāo de indicadores não específicos tem sido favorecida pela capacidade das agências de saúde pública detectar surtos precocemente e pela proliferação de bancos eletrônicos em postos de cuidado à saúde para captação de informações clínicas, tornando a extração, transmissão, processamento e análise de dados factiveis para os propósitos da saúde pública. Dessa forma, detectam aumentos em síndromes dentro de três dias, ao invés de surtos de uma semana ou mais. Existe o debate se um ataque bioterrorista pode ser detectado por um médico treinado ou pela vigilância de sindromes de doenças prodrômicas amplamente distribuidas ou pontuais. 
Segundo DEMBEK et al. (2004), a especificidade de uma doença é modulada pela alteração na definição da informação requerida e do método de análise ou pela incorporação de aspectos de vigilância ativa.

A vigilância de síndromes com investigações de acompanhamento auxiliam os médicos nos problemas das comunidades que se manifestam entre pacientes. O reconhecimento pode ocorrer no hospital, como na discriminação da Febre do Nilo Ocidental em 2002, ou na comunidade, como os alertas em Nova lorque informando médicos sobre doenças gastrintestinais virais (BUEHLER et al. 2004).

A vigilância de síndromes não detecta surtos reconhecidos por métodos tradicionais enfatizando avaliações das características de epidemias e sistemas de vigilância que favorecem a detecção por métodos sindrômicos, portanto a vigilância de síndromes é um auxílio e não um substituto a vigilância tradicional (SICHEL et al. 2003; HEFFERNAN et al. 2004).

Dentre alguns modelos de sistemas de vigilância por eventos sentinelas, a vigilância da síndrome diarréica foi implementada em Novạ lorque em 1995 para detectar surtos do agravo, particularmente associados a Cryptosporidium e Giardia envolvidos em transmissão hídrica e alimentar. Contempla três componentes: vigilância da doença diarréica em instituições de cuidado à saúde, vigilância de amostras clínicas submetidas a testes laboratoriais e rastreamento de vendas de medicamentos para o tratamento da doença (CDC 2004c). 
Outro exemplo importante de vigilância de síndromes diarréicas é o BioSense, uma iniciativa norte-americana para intensificar a capacidade de rápida detecção e localização das emergências de saúde pública, inclusive para surtos de DTA. Caracteriza-se pela transmissão eletrônica de dados em tempo real dos laboratórios clínicos, sistemas hospitalares, ambulatórios, entre outras fontes de informações, para as agências de saúde pública locais, estaduais e federais (LOONSK 2004).

Além desses modelos, em Virgínia, EUA, foi implantado um sistema de vigilância sentinela em repartições hospitalares de emergência para analisar aumentos atípicos de sete síndromes nos hospitais participantes; incluindo a síndrome diarréica na categorização de dados, auxilia a detecção de surtos de DTA (YUAN et al. 2004).

\subsubsection{Vigilância de Base Laboratorial}

Segundo BORGDORFF e MOTARJEMI (1997) e TAUXE (2002), a vigilância de base laboratorial implica em uma rede articulada com uma unidade de referência provida de serviços rotineiros de diagnóstico e especializados para confirmar isolados não usuais e assegurar a qualidade do diagnóstico; fornece reagentes padrão garantindo a qualidade e a uniformização das técnicas. Os atendidos em unidades de saúde cujo laboratório integre este sistema são a população de abrangência; considerase a participação voluntária dos laboratórios e a não padronização de técnicas aspectos que influenciam a cobertura de alguns agentes. 
Segundo esses autores, a vigilância de patógenos que possuem rotas de transmissão pessoa a pessoa e hídrica, pode apresentar limitantes na monitorização de DTA. É útil na avaliação da freqüência de microrganismos específicos de casos isolados ou agregados possivelmente associados e na deteç̧ão de surtos.

Um exemplo de sistema de vigilância de base laboratorial é o $C D C$ National Salmonella Surveillance System, que é um sistema passivo com notificação eletrônica pelo Public Health Laboratory Information System; e ainda, em resposta ao número de surtos, $\circ C D C$ iniciou o $S$. Enteritidis Outbreak Reporting System, também com estas características (PATRICK et al. 2004).

\subsubsection{Vigilância de Base Populacional}

Como exemplo desta abordagem, a Active Bacterial Core Surveillance-ABCs, colaboração entre $\circ C D C$, departamentos estaduais e universidades dos EIPS ; conduz a vigilância ativa de base populacional, coleta isolados e realiza estudos de doenças causadas por Streptococcus pneumoniae, Streptococcus grupos A e B, Neisseria meningitidis e Haemophilus influenzae. Esta atividade essencial dos EIPS determina a incidência e tendências utilizando métodos moleculares e microbiológicos para caracterizar os microrganismos. Estratégias de prevenção são utilizadas com a avaliação do impacto e oportunidades de aplicação; 
representa uma população de 30 milhões e averigua casos de 600 laboratórios de microbiologia clínica (SCHUCHAT et al. 2001).

Além dessas abordagens, incluem-se as doenças de notificação obrigatória ou que sejam contempladas em um sistema nacional de notificação, implicando em diagnóstico clínico e laboratorial específico, sensível e reprodutível; subsidiando a descrição da epidemiologia e o monitoramento de tendências e grupos de risco. No Brasil, dentre as DTA de notificação compulsória destacam-se o botulismo, a cólera, febre tifóide e tuberculose (BORGDORFF e MOTARJEMI 1997; BRASIL 2001).

Outra forma de vigilância é pela análise de dados hospitalares de declarações de óbito e diagnósticos de alta para a estimativa dos casos de DTA e obtenção de informações como causa da morte, nome, endereço, data de nascimento, sexo e data de óbito (BORGDORFF e MOTARJEMI 1997)

Exemplo importante de vigilância pela análise de dados hospitalares é a Asian Rotavirus Surveillance Network que coleta dados para subsidiar a introdução de uma vacina; com a colaboração de hospitais em nove países ou áreas, é uma abordagem regional para doenças passiveis de prevenção por vacinação que facilita o treinamento e representa um paradigma para a vigilância (BRESEE et al. 2004). 


\subsubsection{Investigação Epidemiológica de Campo}

Conduzida na investigação de surtos e epidemias, inclusive de DTA, induz as autoridades sanitárias a identificar oportunamente suas causas e fontes elou rotas de transmissão para o estabelecimento de medidas de controle. Inicia-se freqüentemente sem uma hipótese clara, demandando estudos descritivos para sua formulação; quando surgem problemas agudos que impliquem em medidas imediatas de proteção à saúde, essa atividade deve restringir a quantidade de informações a serem obtidas na coleta de dados e agilizar sua análise, antecipando as ações de controle (WALDMAN 1991).

\subsection{Investigação de Agregados de Eventos Adversos a Saúde (clusters)}

O termo cluster pode ter ao menos dois significados, em microbiologia geralmente é utilizado para designar um determinado clone ou determinados perfis de bandas eletroforéticas caracterizando um clone. Por sua vez, em epidemiologia, o termo cluster pode ser utilizado para designar a ocorrência de possiveis surtos epidêmicos constituídos de casos agregados no tempo ou no espaço ou ainda, no tempo e espaço. Tais eventos caracterizam-se por atingir número reduzido de indivíduos, apresentarem informações incompletas, delimitação geográfica imperfeita, além de maior complexidade em determinar a população exposta ao risco. Destacam-se três objetivos: 
comprovação da ocorrência de um excesso de casos do evento notificado; apuração se o aumento inesperado de casos corresponde a uma epidemia ou a uma variação aleatória e ainda a busca de associação entre o agregado de eventos adversos a fatores de risco (ROTHMAN 1987; WALDMAN 1991; SAUDERS et al. 2003).

\subsection{Investigação de Surto de DTA}

Define-se surto de DTA como a ocorrência de uma manifestação clínica semelhante, decorrente da exposição comum a um alimento suspeito gerando um número de casos da doença acima do esperado (TAUXE 2002a;GERMANO 2003).

TEIXEIRA et al. (2003) descrevem o roteiro de investigação de surtos. A primeira etapa consiste em verificar se a suspeita diagnóstica inicial enquadra-se na definição de caso suspeito ou confirmado; no início da investigação, é importante que esta seja mais sensivel facilitando a identificação, a estimativa da magnitude do surto e os grupos populacionais mais atingidos. Posteriormente confirma-se o surto pela comparação dos dados de incidência na ocorrência do evento com os usualmente verificados na mesma população. A caracterização segundo tempo, lugar e pessoa, formulação de hipóteses, análises parciais e busca ativa de casos são as etapas seguintes, acompanhadas pela busca de dados adicionais, processamento e análise final, recomendação de medidas de controle e divulgação do relatório. 
A investigação do surto é conduzida para identificar a fonte e controlála prevenindo casos adicionais e surtos similares, minimizando prejuízos econômicos. Representa condição para aprender algo novo de um patógeno, sua relação com um novo alimento ou transmissão via uma nova ou inesperada rota. A identificação da fonte depende do estudo de um grande número de casos esporádicos, por exemplo, por um estudo casocontrole, ou de um grupo de casos aparentemente relacionados entre os casos esporádicos, pela investigação do agregado (TAUXE 2002b).

Há vinte anos, a maioria dos surtos de DTA eram pontuais e atribuidos à escassez de boas práticas de manipulação. Os surtos associavam-se a restaurantes ou eventos sociais e eram informados às autoridades de saúde pública pelos telefonemas dos indivíduos afetados. Atualmente, os surtos de DTA envolvem produtos alimentícios de ampla distribuição geográfica previamente contaminados, gerando uma dispersãọ de casos envolvendo estados ou países, afetando uma pequena proporção dos expostos (SWAMINATHAN et al. 2001; TAUXE 2002b; PATRICK et al. 2004).

Considerando o Estado de São Paulo como exemplo, a notificação de doenças pode ser efetuada por qualquer profissional de saúde ou cidadão mediante simples suspeita. As notificações são efetuadas atualmente pelo Sistema de Informações de Agravos de Notificação (SINAN) com a participação dos diferentes niveis do SUS (CVE 2002).

O SINAN, desenvolvido em 1993, surgiu para minimizar as dificuldades do Sistema de Notificação Compulsória de Doenças (SNCD), 
facilitando a formulação e avaliação das políticas, planos e programas de saúde e subsidiando o processo de tomada de decisões para contribuir para a melhoria da condição de saúde da população. Seu objetivo específico é a coleta, transmissão e disseminação de dados gerados rotineiramente pelo sistema de vigilância epidemiológica das três esferas do governo para a análise do perfil de morbidade, incluindo as DTA de notificação compulsória (BRASIL 2002).

Para a investigação dos casos ou surtos de DTA as amostras de alimentos ou clínicas ou ainda as cepas de agentes etiológicos isolados de pacientes envolvidos em surtos de DTA são encaminhadas ao Instituto Adolfo Lutz e após a avaliação ou reavaliação, os resultados são encaminhados ao laboratório de origem, para a vigilância epidemiológica solicitante e para o Centro de Vigilância Epidemiológica da Secretaria Estadual de Saúde de forma a subsidiar as medidas de vigilância sanitária cabiveis (CVE 2002).

A investigação de surtos de DTA, que compõe o Sistema de Vigilância Epidemiológica das Doenças Transmitidas por Alimentos (SVE-DTA) é um sistema de âmbito nacional adaptado às necessidades do estado de São Paulo, que se embasa na notificação de rotina das DTA pela notificação de surtos. Fornece indicadores sobre fatores de risco na produção de alimentos, estabelecimentos envolvidos, tipos de alimentos incriminados, perfil epidemiológico de patógenos e doenças/sindromes, grupos de risco entre outros (EDUARDO et al. 2002; CVE 2002). 


\subsection{Planejamento Estratégico para o Controle de DTA}

O estabelecimento de um programa que responda a uma ameaça microbiana representa um desafio para as autoridades quando não se sabe qual o tipo de agente, o alimento associado ao evento ou quando e onde a emergência ocorrerá. No entanto, o plano de contingência militar adapta-se aos patógenos emergentes para antecipar e responder a ameaças microbianas; este possui quatro componentes: inteligência, pessoal e instalações, rápida resposta e planejamento estratégico (BUCHANAN 1997).

LANGMUIR e ANDREWS (1952) define inteligência, o primeiro componente, como as informações referentes à revelação da fonte ou lugar de exposição pela investigação epidemiológica, a determinação da natureza do patógeno pelo estudo e análise e a elucidação do momento de exposição e do mecanismo de disseminação, proporcionando a compreensão e reconhecimento da abordagem epidemiológica no controle de doenças. É a reunião de informações, médicas e cientificas que permitem a identificação da emergência (BUCHANAN 1997).

O recrutamento e treinamento de um grupo de epidemiologistas, por um curso intensivo de epidemiologia, bioestatística e administração de serviços de saúde pública e sua relação com o controle de doenças transmissíveis, constitui-se em objetivo elementar de um serviço de inteligência pressupondo a existência de instalações apropriadas em áreas estratégicas (LANGMUIR e ANDREWS 1952). 
O segundo componente é assegurar pessoal suficiente e instalaçães para caracterizar um novo agente biológico e desenvolver estratégias de controle. A inabilidade em predizer o agente ou o alimento associado com o grau de especialização requerido dos investigadores, exige capacitação e recursos. A rápida mobilização de recursos é o terceiro componente, importante para os agentes que vivem livremente, pois um dos objetivos é limitar sua disseminação prevenindo que estabeleçam reservatórios secundários (BUCHANAN 1997).

A mobilização de recursos para responder a uma emergência deve ser apropriada à sua gravidade. Uma reação exagerada prejudica a credibilidade do sistema, enquanto que a discreta aumenta o impacto de saúde pública e o econômico. Os esforços de uma resposta rápida estão focalizados na identificação de novos agentes e na remoção de alimentos suspeitos dos pontos de venda. No entanto, para a prevenção de ocorrências de outros patógenos emergentes, a pesquisa tem se mostrado menos organizada e oportuna (BUCHANAN 1997:TAUXE 2002b).

O quarto componente, cronologicamente o primeiro, tem recebido atenção em relação aos patógenos emergentes associados ao uso bélico de agentes biológicos, considerando quais mudanças na sociedade, economia, tecnologia, agricultura, medicina e comércio internacional podem afetar a segurança microbiológica do suprimento de alimentos (BUCHANAN 1997; HEFFERNAN et al. 2004).

A experiência de mobilização de recursos na época da introdução da cólera no Brasil em 1991 suscitou um conjunto de medidas por parte das 
autoridades governamentais, ilustrando estes componentes, exemplificados principalmente por medidas para garantir o controle e a qualidade dos serviços de saúde incluindo hospitais, postos, pronto socorros e laboratórios, bem como o controle e a qualidade da água e dos alimentos além de medidas de controle sanitário em aeroportos e rodovias (CVS 1991)

Um exemplo atual é o programa de monitoramento ambiental de patógenos circulantes e outros tipos de contaminantes para a identificação precoce de fatores de risco para a ocorrência de doenças, desenvolvido pela Companhia de Tecnologia e Saneamento Ambiental - CETESB. Essa atividade gera um banco de dados que subsidia o estabelecimento de medidas para o controle e a construção de tendências sobre o perfil destes agentes possibilitando direcionar medidas adicionais. Os dados sobre as DTA podem ser complementados com informações de Morbidade por Internação (AIH/DATASUS) e Sistema de Informação de Mortalidade (SIM), entre outros (EDUARDO et al. 2002; CVE 2002).

Cabe ainda citar a experiência do CVE na vigilância da E. coli 0157 que se inicia pela notificação imediata dos casos caracterizados por diarréia sanguinolenta e isolamento do agente com envio posterior das cepas ou amostras de fezes para o IAL onde são realizados testes com técnicas de biologia molecular. Posteriormente, realiza-se investigação pelas visitas hospitalares ou domiciliares, monitoramento dos casos e envio contínuo de informações aos diversos níveis (CVE 2002)

Além dessas iniciativas, a vigilância ativa de DTA e água é um programa em implantação com o objetivo de aprimorar as investigações de 
surtos e conhecer a incidência dessas doenças. Tem como base a definição de áreas populacionais adstritas a serviços de saúde e laboratórios públicos e privados, a busca ativa de patógenos emergentes transmitidos por alimentos em laboratórios e a investigação dos casos detectados pela busca em serviços de saúde ou domicilios e inquéritos adicionais para estudos de tendências (EDUARDO et al. 2002; CVE 2002).

Este sistema, a exemplo do descrito neste trabalho, a PulseNet, demanda melhor integração dos laboratórios ao sistema de vigilância epidemiológica, a utilização da biologia molecular na detecção dos microrganismos e uma rede informatizada nas áreas sentinelas vinculadas aos órgão de coordenação central, bem como nas regionais de saúde e nos municipios (EDUARDO et al. 2002; CVE 2002).

No municipio de São Paulo, a coordenadoria de vigilância em saúde (COVISA), desenvolve atividades que visam o controle da qualidade dos alimentos e dos serviços a eles relacionados. A subgerência da vigilância de alimentos é composta por unidades de planejamento e execução das ações de vigilância sanitária dos estabelecimentos do comércio varejista, atacadista e indústria de alimentos. A unidade de vigilância sanitária é centralizada na subgerência e suas açōes são executadas por equipes de médicos veterinários, farmacêuticos e nutricionistas (SMS 2004).

A vigilância à saúde das DTA vinculada a COVISA objetiva a detecção dos fatores desencadeantes, diagnóstico e tratamento. Dentre suas atividades cabe citar a coordenação, supervisão, assessoria, treinamento e capacitação técnica das atividades de vigilância das 
Supervisões de Vigilância em Saúde - SUVIS das 31 subprefeituras, incluindo inquéritos de DTA, inspeções sanitárias de estabelecimentos e coleta de amostras de alimentos encaminhadas ao laboratório de controle de alimentos responsável pelo suporte técnico e laboratorial além de realizar projetos que monitoram e avaliam a qualidade dos alimentos e água na cidade de São Paulo (SMS 2004).

Para fortalecer essas atividades existe um esforço para o estabelecimento de vínculos estaduais, federais, com universidades, com laboratórios de referência e demais instituições de interesse, além de gerenciar e estruturar banco de dados relativo às DTA para divulgar informações às regionais do município de São Paulo de forma a subsidiar as ações programáticas da vigilância de DTA (SMS 2004).

A proposta de articulação dos Laboratórios Nacionais de Saúde Pública enquadra-se no contexto do planejamento estratégico para o controle das DTA, sugerindo nova hierarquização e modificações nas áreas de atuação enfatizando maior eficiência e sensibilidade no diagnóstico laboratorial para as açōes de vigilância em saúde, com enfoque à conformação de sub-redes específicas, priorizando a abordagem sindrômica. Com a nova proposta de organização, apesar da hierarquização indicar os diversos niveis do sistema, em situações de contingência, as amostras para investigação devem ser encaminhadas ao Laboratório de Referência Nacional especifico da rede (FUNASA 2001). 


\subsection{Vigilância Sanitária - Fiscalização}

A fiscalização é o controle do exercício de deveres e direitos, difundindo as normas legais para evitar contravenções e delitos e a aplicação da sanção quando necessária segundo leis da Constituição Nacional. O Ministério da Agricultura do Brasil define como a ação fiscal de verificação de estabelecimentos, produtos, matérias primas, insumos e serviços garantindo o cumprimento da legislação (GRANDE 1999; BRASIL 2002).

Acima de $40 \%$ dos surtos de DTA notificados ao CDC por ano são atribuidos a estabelecimentos que comercializam alimentos. Ordenados segundo aspectos de segurança alimentar, estabelecimentos, segundo estudo realizado no Tennessee, podem ser avaliados pela Internet ou meios locais de comunicação. Um sistema de inspeção para aperfeiçoar a segurança alimentar pode ser uniforme, consistente e enfocado na identificação de características que a afetem (JONES 2004).

Com a publicação da lei $8080 / 90$, a vigilância sanitária no Brasil incorporou atribuições decorrentes da integração das ações e serviços voltados para a saúde do trabalhador e meio ambiente. O Centro de Vigilância Sanitária da Secretaria de Estado da Saúde de São Paulo foi criado com o objetivo de planejar, coordenar, supervisionar, realizar estudos e propor normas e programas, abrangendo quatro subsistemas fundamentais, dentre eles o controle de bens de consumo que se relacionam à saúde, envolvendo todas as etapas e processos de produção até o consumo final, compreendendo matérias primas, transporte, 
armazenamento, distribuição, comercialização e consumo de alimentos, água, bebidas e medicamentos, dentre outros (Brasil 2004a).

Os órgãos nacionais de vigilância sanitária (Visa) realizam ações de fiscalização como inspeções sanitárias em estabelecimentos e análise fiscal de alimentos expostos ao consumo para a certificação da conformidade com os regulamentos legais. Ao identificarem irregularidades sanitárias, os órgãos competentes adotam as medidas legais pertinentes para prevenir possíveis danos à saúde da população, retirando o produto do mercado ou interrompendo sua fabricação (Brasil 2004a).

As Boas Práticas de Fabricação (BPF) no Brasil abrangem um conjunto de medidas que devem ser adotadas pelas indústrias de alimentos visando a garantia da qualidade sanitária e a conformidade dos produtos alimentícios com os regulamentos técnicos. A legislação sanitária federal regulamenta essas medidas em caráter geral, aplicável a todo o tipo de indústria de alimentos (Brasil 2004a).

A vigilância sanitária no comércio de alimentos do Municipio de São Paulo está implementando um modelo de atuação denominado Fiscalização Solidária que tem como fundamento a prevenção de DTA pela atuação conjunta da fiscalização, do comerciante e do consumidor. Dessa forma, à fiscalização cabe controlar a qualidade dos alimentos, orientar tecnicamente o comerciante sobre as exigências das normas sanitárias e executar medidas administrativas previstas na legislação. O comerciante deve cumprir os princípios de organização e higiene, ou seja, as Boas Práticas Operacionais para assegurar a qualidade dos alimentos. Ao consumidor 
cabe realizar o controle da qualidade dos alimentos pelas reclamações e denúncias aos órgãos competentes (SMS 2004).

\subsection{Vigilância de Perigos}

GUZEWICH et al. (1997) a define como a avaliação da ocorrência, distribuição e tendência da prevalência de agentes químicos, físicos ou biológicos, responsáveis por doenças e agravos. Em se tratando da vigilância de perigos relacionados às DTA, cita-se a atividade de inspeção em pontos críticos de estabelecimentos que processam alimentos como objetivo da análise de perigos do sistema de Análise de Perigos e Pontos Críticos de Controle (APPCC) e da avaliação de riscos.

\subsection{Análise de Risco}

Primeiramente, cabe distinguir as diferentes utilizações da terminologia risco. Em se tratando de um estudo epidemiológico, este termo pode ser entendido, segundo definição da CLAP-OPAS/OMS (1988), como a probabilidade de ocorrência de um resultado desfavorável, de um dano ou de um fenômeno indesejado. Dessa forma, estima-se o risco ou a probabilidade de que uma doença exista pelos coeficientes de incidência e prevalência. A definição risco a ser abordada neste tópico refere-se ao risco microbiológico. 
Estratégia para avaliar e gerenciar os riscos microbiológicos constituindo-se de três elementos principais: avaliação de perigos, que inclui a identificação e caracterização, a avaliação de exposição e caracterização de risco; o gerenciamento de risco responsável pela avaliação de risco, opção de gerenciamento de risco, implementação e gerenciamento da decisão, monitorização e revisão; e comunicação de risco (FAOMHO 1995; SCHLUNDT 2002; HOORNSTRA et al. 2001).

Avaliação de risco é o processo científico de determinação da associação da exposição a um perigo sob um conjunto definido de condiçōes e da probabilidade de ocorrência de um efeito adverso à saúde ou doença; estima o risco contemplando expressões quali e quantitivas e indicadores contínuos de incertezas em quatro etapas: Identificação de risco: efeitos conhecidos à saúde relacionados a um agente que pode estar presente em um alimento; caracterização de perigo: avaliação dos efeitos adversos associados com o perigo; avaliação de exposição: avaliação do grau de exposição e da ingestão do perigo e caracterização de risco: integração da identificação e caracterização de perigos e avaliação da exposição na estimativa dos efeitos adversos prováveis (MAYES 1998; SCHLUNDT 2002; MCLAUCHLIN 2004).

O gerenciamento de risco é um processo de ponderação de alternativas políticas e seleção apropriada de opções de controle e prevenção, fundamentadas na avaliação de risco, identificação de pontos com efeitos expressivos na exposição e de um nivel aceitável de risco, reduzindo-o. A comunicação de risco consiste na troca de informações e 
pareceres a respeito do mesmo entre os assessores e administradores de risco além de outras facções interessadas, pelo processo de análise de risco (MAYES 1998; SCHLUNDT 2002; MCLAUCHLIN 2004; CONFERENCE REPORT 2004).

Esse elemento determina como os riscos são percebidos pela sociedade e afere o nivel aceitável. A aceitabilidade nem sempre está diretamente correlacionada com o nível de risco. O efeito das percepções na aceitabilidade do risco (incluindo a imparcialidade da distribuição de risco, os benefícios associados ao risco, o temor ao risco, a proporção do controle individual sobre a exposição ao perigo que pode ser alcançada e a fidedignidade dos comunicadores de risco) podem ser discutidas no contexto de um surto de DTA (MCLAUCHLIN 2004).

Segundo o Codex Alimentarius, a segurança alimentar (food safety) é a garantia de que o alimento não causará dano, quando preparado e ou consumido de acordo com o uso proposto. A inocuidade dos alimentos é decorrente do controle da fonte, tipo de produto e controle do processo de produção e pela aplicação de Boas Práticas de Fabricação durante a produção, processamento, manipulação, distribuição, armazenamento, venda, preparação e utilização, em conjunto com a aplicação do sistema APPCC. A administração da segurança alimentar requer a avaliação de risco, gerenciamento de risco e comunicação de risco, atividades extensivamente inter-relacionadas (MIYAGISHIMA et al.. 1995 ; ORRISS e WHITEHEAD 2000; MCLAUCHLIN 2004). 
Convencer os individuos a aceitarem um risco ou responsabilizar instituições e a mídia são ineficientes no contexto da segurança alimentar e aceitabilidade de risco. O impacto negativo dos surtos de encefalopatia espongiforme bovina deveu-se à negação pelas agências reguladoras da existência de incertezas, enquanto que o público as conhecia, acreditando que estas foram ocultadas pelos patrocinadores para a promoção dos interesses investidos (CONFERENCE REPORT 2004).

Estudo realizado por GIOVANNINI (2004) na avaliação quantitativa de risco de infecção por Salmonella spp contemplando consumidores de produtos suínos, envolveu a estimativa da prevalência de contaminação segundo tipo e origem; avaliação do consumo pelos residentes na região de estudo; avaliação quantitativa da contaminação; avaliação da exposição do consumidor; avaliação de risco de infecções clínicas de consumidores; validação do modelo preditivo.

O desenvolvimento de uma abordagem interdisciplinar reconhecendo a necessidade de interação direta entre vigilância e sistemas de análise de risco é fundamental para a prevenção de DTA (SCHLUNDT 2002).

\subsection{Monitorização como Instrumento para o Controle das DTA}

A monitorização pode ser aplicada para analisar indicadores de qualidade de produtos de consumo humano, subsidiando medidas relativas à fiscalização, educação sanitária, identificação de necessidades de pesquisas científicas, de desenvolvimento tecnológico ou recomendando 
alterações na legislação. A análise contínua de indicadores de morbimortalidade detecta modificações nas condições de saúde, buscando suas causas e caracterizando seus efeitos com o desenvolvimento subseqüente de sistemas de vigilância especificos (WALDMAN 1991).

A monitorização de indicadores de qualidade microbiológica ou de contaminantes químicos constitui-se em um componente essencial para a segurança dos alimentos sendo aplicada de forma sistemática para a análise contínua dos mesmos cooperando para a definição do risco de exposição para agentes potenciais e do impacto de medidas de controle (POTTER e TAUXE 1997).

No estado de São Paulo, a Monitorização da Doença Diarréica Aguda é um programa proposto pelo Ministério da Saúde implantado em unidades sentinelas municipais representativas da doença que proporciona o estudo de tendências, a detecção precoce de surtos e epidemias e problemas na cadeia de produção de alimentos entre outros (EDUARDO et al. 2002; CVE 2002).

Os dados são analisados semanalmente e, se necessário, dados adicionais são coletados. Em se tratando de surtos, a unidade de saúde notifica à vigilância epidemiológica do município ou da região de saúde (DIR) desencadeando investigaçōes mais detalhadas e possibilitando conhecer o perfil da doença diarréica, identificar pontos críticos e servir como alerta para o sistema de possiveis DTA (CVE 2002). 


\subsection{Análise de Perigos e Pontos Críticos de Controle - APPCC}

O advento de sistemas de controle preventivo, dentre eles o APPCC, combinado à utilização de novas tecnologias e à modernização dos sistemas regulatórios, incorporam o potencial de intensificar a segurança microbiológica dos alimentos. O sistema APPCC (Hazard Analysis and Critical Control Points - HACCP) provê uma rede de trabalho conceitual sistemática para a identificação de perigos, enfocando esforços no funcionamento adequado da chave da produção alimentar (pela aplicação de medidas de controle cientificamente fundamentadas) processamento e atividades de marketing (DeWAAL 2003).

O sistema é capaz de identificar e monitorar perigos de origem alimentar que afetam a segurança, proporcionando o estabelecimento dos PCC. Apresenta uma abordagem científica baseada na análise critica do sistema de produção de alimentos e na identificação e controle de perigos de maneira contínua (MOTARJEMI e KAFERSTEIN 1999; DeWAAL 2003)

Sua utilização iniciou-se nos EUA por um programa de controle desenvolvido pela indústria e agências governamentais regulatórias para o botulismo. Separando as atividades essenciais de avaliação de concordância regulatória, alcançou-se o enfoque sistemático de recursos prevenindo os erros de processamento pela identificação de perigos e discussão das áreas críticas para o controle do processo (KVENBERG et al. 2000). 
Seus princípios foram desenvolvidos pelo National Advisory Committee on Microbiological Criteria for Foods (NACMCF): 1 - Efetuar a análise de perigos e identificar as medidas preventivas; 2 -Identificar os PCC; 3- Estabelecer procedimentos de controle e padrões para os PCC; 4Monitorar os PCC; 5- Estabelecer ações corretivas; 6- Desenvolver sistema de registro; 7-Verificar o funcionamento do sistema (VACLAVIK 1998; DeWAAL 2003).

Em um surto de listeriose ocorrido na França em 1993 pela contaminação cruzada do alimento com carne crua decorrente de um processo ineficiente de desinfecção, após implementação do sistema APPCC, o diagrama de fluxo foi modificado minimizando o risco de contaminação (MOTARJEMI e KAFERSTEIN 1999).

No período de 1996 a 1999, a taxa de doenças relacionadas à Salmonella declinou de 14,5 para 13.6 casos por 100.000 nos EUA; talvez essa queda possa ser reflexo de uma flutuação aleatória, necessitando um estudo mais detalhado para atribuí-la às medidas de prevenção da campilobacteriose e salmonelose, que incluem modificações nọ processamento de carnes e aves induzidas pela APPCC cuja aplicação foi considerada obrigatória pelo Departamento de Agricultura dos EUA (USDA). Porém, o sucesso na prevenção de DTA depende da correta aplicação e combinação com outros sistemas de administração de segurança alimentar, incluindo a provisão de infra-estrutura sanitária e a aplicação dos princípios de boas práticas de higiene (MOTARJEMI e KAFERSTEIN 1999; DeWAAL 2003) 
Além desses fatores a implementação do APPCC depende do conhecimento da virulência dos microrganismos, caminhos nos quais contaminam o alimento, efeitos do processamento e preparação na sua sobrevivência, padrões de consumo alimentar e caracteristicas culturais. Dessa forma, não pode ser aplicado para controlar perigos desconhecidos, como patógenos de origem alimentar emergentes. O controle de uma nova ameaça microbiana de origem alimentar requer o conhecimento do perigo pela aquisição oportuna dos dados de pesquisa (BUCHANAN 1997; WOTEKI E KINEMAN 2003; DEWAAL 2003).

Os problemas relativos à segurança alimentar em países em desenvolvimento são maiores, afetando milhões de pessoas; com exceção das companhias exportadoras de alimentos, a aplicação do sistema APPCC tem sido feita com pouco progresso (MOTARJEMI e KAFERSTEIN 1999).

As autoridades governamentais incumbem-se do mandato regulatório para a implementação do sistema, da certificação que o planejamento atua conforme os princípios gerais, do estabelecimento dos limites críticos; de critérios, métodos e modelos de planejamento, da verificação das instalações, da utilização de informações epidemiológicas e cientificas identificando perigos e conduzindo avaliação de risco, do subsidio de pesquisas relacionadas aos $\mathrm{PCC}$, limites críticos e monitoramento de procedimentos, da cooperação para identificar perigos e estratégias de controle; da participação em programas educacionais e ainda da cooperação com a indústria no planejamento geral e no exercício de ações de prevenção (KVENBERG et al. 2000; FIDLER 2003). 
A indústria, segundo o NACMCF, deve desenvolver, implementar e manter um sistema efetivo de APPCC, em que cada instalação tenha uma equipe responsável pelo planejamento e mantenha um plano de APPCC acurado e atualizado (KVENBERG et al. 2000).

O sistema não é uma panacéia para os problemas de segurança alimentar, tratando-se de uma ferramenta que orienta a identificação de perigos e de medidas de controle, garantindo que as críticas sejam aplicadas, intensificando a segurança do suprimento de alimentos; além disso, a fragilidade dos sistemas regulatórios não garante sua implementação plena na indústria de carnes,aves e frutos do mar. (MOTARJEMI e KAFERSTEIN 1999; DeWAAL 2003)

À aplicação inconsistente do APPCC decorre da existência de agências cujas responsabilidades são desconectadas considerando o processo regulatório da segurança alimentar; de falhas nos sistemas de proteção ao consumidor, padrões conflitantes de saúde pública, redundâncias regulatórias, falta de agilidade na aprovação de tecnologias e ausência da garantia da segurança desde o início do processo produtivo (farm-to-table food safety). A experiência com a implementação da APPCC revelou que a coordenação entre as agências governamentais não é suficiente e que uma reforma mais profunda é necessária (DeWAAL 2003). 


\subsubsection{Aplicação de Elementos da Análise de Risco ao APPCC}

Enquanto o produto da análise de risco é uma estimativa numérica da ocorrência de um agravo específico o da APPCC é uma lista de perigos significantes juntamente com os PCC, Limites Críticos, Monitoramento e Ações Corretivas. A APPCC pode ser aplicada efetivamente sem o envolvimento de técnicas de análise de risco, sendo internacionalmente reconhecida como uma maneira efetiva de controlar perigos de origem alimentar. Embora o conceito inicial do sistema APPCC contemplasse a categorização de risco, este era um sistema de escala qualitativo; os critérios utilizados no planejamento de um sistema APPCC são baseados em dados qualitativos e não quantitativos. (MAYES 1998; DeWAAL 2003).

A APPCC desenvolve-se em um sistema que identifica os perigos microbiológicos, químicos e físicos, determina os PCC, Limites Críticos, monitora ações corretivas e procedimentos, cooperando com os sete princípios do Codex 1993 e 1997. Na análise de perigos, a significância é avaliada considerando os riscos e a gravidade. Os perigos julgados de baixa significância e gravidade/risco são eliminados da análise. No entanto, existe dúvida de que a maioria dessas considerações seja qualitativa e não quantitativa (MAYES 1998).

No entanto, o uso de elementos da análise de risco é proposta para habilitar decisões sob uma abordagem quantitativa do estágio da análise de perigos, principio um do Codex Alimentarius e da identificação de Limites Críticos, princípio três, além da estimativa da probabilidade de efeitos 
adversos à saúde segundo o consumo de um produto específico. A atualização do Codex 1997 dos "Principios e diretrizes para a sua aplicação" sugere modificação na maneira como a análise de perigos deve ser conduzida, porém sem menção à utilização da análise de risco (MAYES 1998; HOORNSTRA et al. 2001).

Para este objetivo, a equipe da APPCC pode aprimorar a natureza quantitativa da análise pela utilização de modelos preditivos de crescimento microbiológico, sobrevivência e óbito, fornecendo orientação nọ estabelecimento de decisões sobre a segurança alimentar e em relação a como os microrganismos são afetados por parâmetros como atividade de água, pH, temperatura, condições de acondicionamento e preservação; possibilitando à equipe de estudos da APPCC predizer os efeitos do processamento no número de microrganismos e permitindo uma estimativa quantitativa de perigos (MAYES 1998; HOORNSTRA et al. 2001).

A análise da significância de perigos é intensificada pelo desenvolvimento de técnicas na avaliação de risco quantitativa; enquanto os Limites Críticos identificados na análise são baseados em atributos físicos e químicos (tempo/temperatura, $\mathrm{pH}$ ), aquelas, referem-se a critérios microbiológicos baseados na gravidade do perigo e no risco tolerado. $O$ desenvolvimento de técnicas de avaliação de risco microbiano é um ponto crítico para o estabelecimento da associação entre critérios microbiológicos e o impacto para a saúde pública (MAYES 1998; DeWAAL 2003).

Pela articulação de modelos como a inativação térmica, doseresposta, estimativa da distribuição quantitativa de microrganismos em um 
produto específico e o efeito da variação do tratamento térmico, é possível predizer os indivíduos susceptíveis (MAYES 1998; HOORNSTRA et al. 2001).

O uso da avaliação de risco na APPCC pelas indústrias alimentícias ainda não é uma opção pela escassez de dados. O estreitamento entre os cientistas da análise de risco com os adeptos da APPCC, sob orientação do Codex, permitirá que essa abordagem se concretize no futuro (MAYES 1998; HOORNSTRA et al. 2001).

\subsection{Técnicas de Controle Microbiológico}

Técnicas para intensificar a segurança do suprimento de alimentos são utilizadas na indústria de processamento para reduzir ou prevenir a introdução e sobrevivência de microrganismos. Métodos físicos de preservação incluem desidratação, freeze-drying, tratamento térmico ou îrradiação; conservantes químicos, como agentes antimicrobianos, ácidos orgânicos e sal podem reduzir os niveis de contaminação (MENG e DOYLE 2002, WOTEKI e KINEMAN 2003; GILL et al. 2003).

Pasteurização, esterilização e fermentação têm sido utilizadas na indústria alimentar por séculos, no entanto, o aquecimento excessivo pode causar alterações sensoriais indesejáveis e perda de nutrientes. Novas técnicas têm sido desenvolvidas como o processamento em alta pressão, radiações ionizantes, campo elétrico pulsado e radiação ultravioleta (MENG e DOYLE 2002; JONES et al. 2003). 
As conseqüências econômicas e à saúde da contaminação de alimentos diferem entre países, dependendo do clima, situação geográfica, tipo de safra e o grau de desenvolvimento econômico e social, no entanto, os princípios básicos de prevenção e controle são similares consistindo na garantia da qualidade higiênica de matérias alimenticias cruas na agro; hidrocultura e pecuária e pela educação dos manipuladores em relação aos principios de preparo, condições de armazenagem e contaminação cruzada (KAKU et al. 1995; PERESI et al. 1998; KAFERSTEIN 2003).

\subsection{Microbiologia Preditiva}

A microbiologia preditiva (MP) é uma metodologia que supre as limitações da microbiologia convencional (onerosa e dispendiosa, simula os efeitos ambientais para a análise do crescimento e proliferação de microrganismos patogênicos e contaminantes), agregando a engenharia, a matemática, a microbiologia e a química realizando predições do comportamento dos microrganismos sob condições definidas pelos modelos preditivos: expressão matemática que descreve o crescimento, sobrevivência, inativação ou processo bioquímico de um microrganismo (ARMITAGE 1997; MACDONALD 1999).

Dessa forma, permite a avaliação da exposição a determinado patógeno por modelos matemáticos, gerados pela cultura de microrganismos sob condições como temperatura, potencial hidrogeniônico e atividade de água, cujos dados são ajustados à equação (WHITING 1997; WALLS 1997). 


\subsection{Vigilância e Controle das DTA}

Os instrumentos citados podem ser utilizados para controlar e prevenir estes agravos, porém, todos os setores envolvidos: governo, indústria (produtores do setor primário, setor de processamento de alimentos, estabelecimentos comerciais, fornecedores e varejistas) e consumidores devem compartilhar a responsabilidade, pressupondo que a segurança alimentar deve ser acompanhada ao longo da cadeia. 


\section{Objetivos}

\subsection{Objetivo geral}

Apresentar novas abordagens da vigilância para as DTA e discutir a viabilidade e o interesse de sua implantação no Brasil.

\subsection{Objetivos especificos}

- Discutir os fundamentos conceituais da estratégia de vigilância representada pela PulseNet, contextualizados na mudança do comportamento das DTA

- Sistematizar e discutir as bases técnicas e operacionais da PulseNet com vistas a oferecer subsidios a implantação de um modelo similar em nosso meio. 


\section{Métodos}

Este trabalho constará de uma monografia que abordará o tema: novas abordagens da vigilância de DTA, abrangendo uma revisão discutida e atualizada do tema, abordando-o em pormenores, de forma sistematizada, atendendo, portanto a definição de monografia formulada por ALMEIDA (1996), qual seja o desenvolvimento do tema escolhido através da pesquisa, análise, seleção e interpretação de conhecimentos disponiveis na literatura, apresentados sob nova sistematização.

\subsubsection{Delimitação do tema}

O tema escolhido foi o processo de transformação do comportamento das DTA em função das características do modelo de desenvolvimento econômico das últimas décadas e as novas estratégias da vigilância das DTA visando oferecer subsídios ao aprimoramento das estratégias de controle desses agravos.

3.1.2. Seleção das fontes bibliográficas para a elaboração da monografia

Realizar-se-á revisão bibliográfica sobre o tema, abrangendo os últimos cinco anos, selecionadas a partir das bases de dados LILACS, 
Medline, Probe e OVID complementando com referências da OMS e do Ministério da Saúde entre outras.

A busca nessas bases de dados utilizará as seguintes palavras-chave em idioma português e em inglês: doenças transmitidas por alimentos (foodborne disease/illness), vigilância (surveillance), controle (contro), alimentos (food), segurança alimentar (food safety); controle sanitário dos alimentos (food control), fiscalização (law enforcement), pesquisa (research), microbiologia preditiva (predictive microbiology), monitorização (monitoring), investigação de surto (outbreak investigation), legislação (legislation), fiscalização (law enforcement), Sistema de Análise de Perigos e Pontos Críticos de Controle - APPCC (HACCP system); análise de risco (risk analysis); avaliação de risco (risk evaluation); Gerenciamento de risco (risk management); Sistemas nacionais de segurança alimentar (national systems of food safety). 


\section{Desenvolvimento do Tema}

\subsection{Pulsenet - Características Gerais}

Pulsenet, rede nacional de caracterização molecular para vigilância de DTA foi estabelecida pelo CDC-USA e laboratórios dos departamentos de saúde estaduais para a caracterização de patógenos com finalidades epidemiológicas. Iniciou com a caracterização da Escherichia coli 0157:H7 e inclui atualmente 46 laboratórios centrais (LACEN) estaduais, dois locais, laboratórios do Food and Drug Administration (FDAIUSA), do Departamento de Agricultura e laboratórios canadenses sob coordenação do National Laboratory for Enteric Pathogens e o Canadian Science Centre for Human and Animal Health Winnipeg, Manitoba (SWAMINATHAN et al. 2001; WOTEKI E KINEMAN 2003).

o CDC com a colaboração da Association of Public Health Laboratories- APHL selecionaram LACEN estaduais em Massachusetts, Minnesota, Washington e Texas para compor a rede. A tipagem padrão por Pulsed Field Gel Eletroforesis (PFGE) e a tecnologia de análise de padrões foi transferida aos laboratórios regionais que provêm o serviço para os estados vizinhos ( WOTEKI e KINEMAN 2003; PINNER et al. 2003).

Dentre os objetivos destacam-se a rápida detecção, investigação e controle de surtos, auxiliando na redução de sua extensão, pois as agências regulatórias e companhias de alimentos utilizam as informações para 
recolher oportunamente produtos envolvidos (SWAMINATHAN et al. 2001; WOTEKI e KINEMAN 2003).

Segundo WOTEKI e KINEMAN (2003), a Pulsenet disponibiliza aos laboratórios um sistema eletrônico de confirmação de padrões moleculares obtidos por PFGE de microrganismos isolados de pacientes ou de amostras de alimentos.

Quatro patógenos veiculados por alimentos, $E$ coli O157: H7, sorotipos não tifóides de Salmonella, Listeria monocytogenes e Shigella são caracterizados e outras bactérias, vírus e parasitas serão adicionados. Recentemente, foi incluido Campylobacter (SWAMINATHAN et al. 2001; WOTEKI e KINEMAN 2003).

A caracterização molecular de proteínas ou ácidos nucléicos de bactérias é aplicada com sucesso no auxilio às investigações epidemiológicas de surtos de DTA desde o seqüenciamento de plasmídios há 20 anos. Métodos para identificação de fragmentos de restrição no DNA cromossômico são desenvolvidos e a caracterização molecular tornou-se um componente essencial de investigações epidemiológicas de doenças infecciosas (SWAMINATHAN et al. 2001).

A descentralização da caracterização e a disseminação da metodologia padronizada aos LACEN proporcionou resultados mais oportunos, informando os epidemiologistas no exercício da investigação, além da caracterização rotineira de isolados permitir a identificação de surtos que não o seriam de outra forma. A utilização de métodos de caracterização padronizados permite a comparação de isolados de 
diferentes regiões, identificando surtos de ampla distribuição, particularmente aqueles cujos casos apresentam-se geograficamente desconectados (SWAMINATHAN et al. 2001; PATRICK et al. 2004).

Submetendo os padrões de PFGE ao banco de dados nacional relacionam-se casos aparentemente não associados devido à dispersão geográfica. Uma vez que um cluster é detectado pelo sistema, a investigação epidemiológica é iniciada para determinar a fonte comum (SWAMINATHAN et al. 2001;TAUXE 2002b).

Os resultados de diferentes laboratórios são comparados on-line e em relação a um banco nacional do $C D C$. Pela rede (Internet), realiza-se a comparação entre os resultados do PFGE, rastreando um novo patógeno ou - aumento de um padrão em diferentes localizações geográficas. Detectando um cluster, a investigação epidemiológica detalhada pode definir a fonte, consistindo em uma potente combinação de métodos microbiológicos e epidemiológicos (TAUXE 2002b).

A avaliação de isolados de agregados com perfis especificos ou surtos identificados pela vigilância epidemiológica de rotina dos laboratórios contribui para o reconhecimento precoce de surtos e rápida identificação das fontes aproximando epidemiologistas e microbiologistas no sistema de saúde pública (SWAMINATHAN et al. 2001).

Para avaliar a reprodutibilidade dos padrões de bandas nos diferentes laboratórios foi utilizado um Kit para cepas de E. coli 0157:H7; seguindo-se os protocolos, os resultados foram reprodutíveis e os padrões de DNA gerados, comparáveis. Os isolados foram inclusos em duplicata para avaliar 
a reprodutibilidade intralaboratorial dos padrōes de PFGE (SWAMINATHAN et al. 2001).

\subsection{Equipamento Padronizado para os Laboratórios Participantes}

Os laboratórios credenciados utilizam CHEF-DRII, CHEF-DRIII ou CHEF-Mapper para PFGE de DNA bacteriano. Embora todos possam ser

utilizados na execução dos protocolos, CHEF-Mapper permite maior flexibilidade no desenvolvimento de condições de separação eletroforética e seqüência de pulsos não linear. Depois da eletroforese os géis são corados com brometo de etídio e os padrões de PFGE convertidos para o formato TIFF pelo Gel-doc 1000 ou outro equipamento de aquisição de imagem. BioNumerics (Applied Maths, Kortrijk, Bélgica) é o programa utilizado para análise dos padrões (SWAMINATHAN et al. 2001; TAUXE 2002b).

\subsection{Banco de Dados Nacional e Informações Epidemiológicas} Associadas

Um banco de dados nacional de padrões de PFGE é reunido no servidor do Pulsenet no CDC. Para cada bactéria, o padrão de PFGE normalizado está associado com uma base de dados padrão e informações epidemiológicas e clínicas para isolados. Um isolado pode associar-se com mais de um padrão de PFGE porque os protocolos do Pulsenet podem implicar no uso de mais de uma enzima de restrição para a discriminação 
de isolados epidemiologicamente não relacionados (SWAMINATHAN et al. 2001; PINNER et al. 2003).

Dessa forma, sete laboratórios (quatro LACEN estaduais, FDACFSAN, USDA-FSIS e CDC) possuem acesso direto, pela Internet, ao servidor que contempla as informações associadas aos padrões de PFGE e suas respectivas consideraçōes epidemiológicas (SWAMINATHAN et al. 2001;TAUXE 2002b).

Os laboratórios procuram por padrões idênticos ou próximos no banco de dados americano (>95\% pareamento), acessando as informações epidemiológicas. A mensagem "novo pareamento" aparecerá no monitor caso dois ou mais laboratórios submeteram padrões idênticos ou estreitamente relacionados dentro de um periodo específico alertando os laboratórios sobre a possibilidade de ocorrência de surtos de DTA em diversos estados (SWAMINATHAN et al. 2001; TAUXE 2002b).

Os laboratórios que não possuem acesso on-line ao servidor do Pulsenet submetem imagens brutas com extensão TIFF e padrões de PFGE normalizados (arquivos bundle) à equipe de administração do banco de dados por e-mail ou via protocolos de transferência de arquivos, esta se incumbe da comparação dos padrões submetidos àqueles contemplados no banco enviando os resultados aos laboratórios solicitantes (SWAMINATHAN et al. 2001; TAUXE 2002b). 


\subsection{Protocolos Padronizados}

Protocolos padronizados foram desenvolvidos em função da habilidade do PFGE em discriminar cepas e a utilidade epidemiológica das informações resultantes para E.coli 0157:H7, Salmonella enterica sorotipo Typhimurium, L. monocytogenes e Shigella. O protocolo da S. Typhimurium é aplicável a sorotipos não tifóides de Salmonella, incluindo $S$. Enteritidis. No entanto, PFGE não provê discriminação aceitável entre cepas deste sorotipo clonal. Protocolos de PFGE padrão para Campylobacter jejuni, C. coli e Clostridium perfringens estão sob desenvolvimento e validação. $O$ desenvolvimento de protocolos para $C$. jejuni e $C$. coli não é prioridade, pois, apesar das infecçōes por esses agentes serem comuns, essas bactérias ocasionam surtos com baixa freqüência. C. perfringens raramente ocasiona surtos de grande amplitude sendo que os LACEN solicitaram um protocolo para auxiliar às investigações de surtos locais (SWAMINATHAN et al. 2001; LINDSAY et al. 2002).

Os protocolos incluem procedimentos baseados no protocolo de PFGE desenvolvido pelo LACEN estadual de Washington em resposta a necessidade de técnicas mais oportunas, sendo que os novos protocolos e alterações dos existentes são avaliados no laboratório responsável e no CDC. Dentre os critérios de avaliação cita-se a reprodutibilidade dos padrōes, o quanto a cepa é apropriada (appropriateness) como padrão de referência e o vigor (robustness) do procedimento. Oficialmente adotado, 
nenhuma modificação pode ser realizada exceto por uma petição à equipe do CDC (SWAMINATHAN et al. 2001).

Em 2000, pacientes de cinco paises Europeus foram infectados por uma cepa multiresistente de Salmonella Typhimurium DT204b. As investigações epidemiológicas foram facilitadas pela transmissão das imagens eletrônicas de perfis de PFGE por uma rede similar ao PulseNet em processo de implantação na Europa. enfatizando a importância da utilização de protocolos padronizados para a tipagem molecular em surtos internacionais de DTA (LINDSAY et al. 2002).

O desenvolvimento e avaliação de protocolos padronizados, o suporte técnico aos laboratórios, a organização e condução de treinamentos e a manutenção da base de dados dos padrões de PFGE das bactérias sob vigilância são de incumbência da equipe operacional do Pulsenet (SWAMINATHAN et al. 2001).

\subsection{Controle de Qualidade e Programa de Segurança}

Um programa de garantia de qualidade foi instituído para a fidedignidade dos resultados das técnicas de PFGE padronizadas. Consiste da padronização de programas de treinamento, procedimentos analíticos, documentação, equipamentos, procedimentos operacionais, certificação inicial do kit de isolados para cada organismo e um programa contínuo de teste de proficiência. Os padrões detalham os pré-requisitos de laboratório para o treinamento, procedimentos de análise, documentação manutenção e 
calibração de equipamentos, testes de proficiência e revisão de resultados (SWAMINATHAN et al. 2001; TAUXE 2002b).

Os procedimentos operacionais padrão descrevem as condutas para manutenção de registros e equipamentos, aquisição de imagem em gel, análise de dados e políticas administrativas. $O$ teste para a aquisição da certificação consiste de isolados com padrões conhecidos para caracterização segundo o protocolo padronizado e envio das imagens para a equipe de administração do banco de dados americano para revisão. Esta equipe é responsável pela atualização do banco, revisão dos padrões submetidos, verificação da compatibilidade e avaliação dos dados da certificação submetidos pelos laboratórios. A aquisição dos certificados permite aos laboratórios compararem resultados com o banco de dados americano. Os laboratórios enviam uma combinação de isolados e arquivos TIFF semestralmente para testar a capacidade de realizar o protocolo padronizado e assegurar que a análise está consistente entre os mesmos (SWAMINATHAN et al. 2001).

O manual de garantia e controle de qualidade descreve o treinamento padronizado, os procedimentos administrativos e laboratoriais e as políticas. Um manual de teste de proficiência é desenhado para manter a reprodutibilidade dos padrões e a consistência na análise (SWAMINATHAN et al. 2001; TAUXE 2002b).

Os laboratórios que se filiam ao PulseNet enviam os protocolos de PFGE padronizados e o conjunto de certificados apropriados ao organismo testado. $\mathrm{O}$ treinamento é listado e o acompanhamento conduzido em função 
da auditoria dos certificados e da regularidade do programa do teste de proficiência. Encontro anual permite discutir novos protocolos, aprimorar softwares e trocar informações de dificuldades e soluções (SWAMINATHAN et al. 2001; PINNER et al. 2003).

\subsection{Nomenclatura Padronizada para os Padrões de PFGE}

A principal dificuldade na comparação e interpretação de informações da caracterização molecular de diferentes laboratórios é a falta de um sistema de nomenclatura universal para os padrões de PFGE. Como forma de minimizá-la, desenvolveu-se um sistema de nomenclatura padronizada. Cada padrão no banco de dados é representado por um código de 10 caracteres: $\underline{X X X Y Y Y} . \underline{0000}$

Os três primeiros caracteres representam o patógeno bacteriano, os próximos três caracteres referem-se a enzima de restrição utilizada para o DNA bacteriano e os últimos representam a designação do padrão. Por exemplo, na designação do modelo EXHA26.0026, EXH representam E. coli 0157:H7, A26, a endonuclease de restrição Avrll e 0026 é o número do padrão. Os números do modelo são designados seqüencialmente para os padrões únicos, nenhuma associação evolutiva, filogenética ou clonal pode ser implicada na disposição dos mesmos (SWAMINATHAN et al. 2001).

Ordem prioritária foi desenvolvida para a inclusão de patógenos: Escherichia coli $0157: \mathrm{H} 7$; sorotipos de Salmonella não tifóide; Listeria monocytogenes; Shigella sonnei; Clostridium perfringens; Campylobacter 
jejuni; Vibrio parahaemolyticus; V. cholerae; Clostridium botulinum; Outras $E$. Coli patogênicas; Yersinia enterocolitica. A priorização considera a disponibilidade de um método de caracterização molecular aceitável, a gravidade da doença causada, propensão do agente em causar surtos e o potencial em reconhecer surtos e estabelecer medidas de prevençāo pela caracterização de rotina (SWAMINATHAN et al. 2001).

\subsection{PulseNet em Investigações de Surtos}

O PulseNet desempenha diversas funções na detecção, investigação e controle de surtos. A identificação do aumento de um sorotipo especifico de um determinado patógeno pode representar indicativo de um surto em sua fase inicial. Os padrōes de PFGE submetidos ao banco proporciona a associação de casos aparentemente desconectados e geograficamente dispersos. Uma vez o perfil especifico detectado, inicia-se a investigação epidemiológica para determinar a fonte comum. A investigação é orientada pelos subtipos revelados pelo PFGE e identificados pelo PulseNet, que é capaz de identificar casos em outras áreas e definir o escopo geográfico do surto. Discriminando uma fonte alimentar $e$ isolando o patógeno, a caracterização pode auxiliar na confirmação da cepa envolvida. Implementando as medidas de controle, a PulseNet atua na confirmação do fim do surto demonstrando o decréscimo na circulação da cepa envolvida na(s) comunidade(s) afetada(s) (SWAMINATHAN et al. 2001; TAUXE 2002b). 
Epidemiologistas dos departamentos de saúde de Washington e Seattle King investigaram um surto de infecçōes por E. coli O157:H7, em quatro estados e uma província Canadense e atribuíram-no a um suco de maçã comercial não pasteurizado. A análise do perfil obtido por PFGE no LACEN estadual de Washington demonstrou que os isolados dos pacientes e do suco representavam a mesma cepa. O reconhecimento do suco como a fonte do surto resultou no rápido recolhimento deste produto (SWAMINATHAN et al. 2001).

Em 1997, o LACEN do estado de Colorado, que iniciara a caracterização da $E$. coli $0157: \mathrm{H} 7$, identificou um perfil específico de 14 indivíduos cujos isolados apresentavam padrões idênticos de PFGE. Simultaneamente, o laboratório da USDA isolava uma cepa do agente em carne moída do alimento consumido por um indivíduo que adoecera. $O$ perfil de banda obtido por PFGE a partir dos isolados humanos do Colorado e do isolado do alimento do USDA-FSIS foram realizados pelo protocolo padronizado do PulseNet. Os padrões de PFGE foram transmitidos ao $C D C$ via Internet, concluindo serem indistinguíveis. Este padrão foi transmitido aos diversos sites do PulseNet e comparados com mais de 300 outros isolados de E. coli O157:H7. Nenhum padrão semelhante foi encontrado, evidenciando que o surto não possuia amplitude nacional (SWAMINATHAN et al. 2001).

O PulseNet auxiliou a investigação de dois perfis específicos de banda referentes a infecção por $E$. coli $\mathrm{O} 157: \mathrm{H} 7$, no nordeste dos EUA. $\mathrm{O}$ seqüenciamento oportuno dos isolados do agente revelaram 32 isolados em 
quatro estados com o mesmo padrão de PFGE e 25 isolados nos cinco estados com um segundo padrăo, implicando dois supermercados que receberam carne moída de um distribuidor comum. Sem o auxílio do PulseNet, seria difícil identificar os casos de cada agregado (SWAMINATHAN et al. 2001; CDC 2004b).

Departamentos de saúde pública em Illinois e Pensilvânia informaram - CDC do aumento de infecções por Salmonella agona. Dados de vigilância específicos por sorotipo de outros estados também apresentavam aumento da infecção. A investigação conduziu a um cereal de aveia proveniente de uma fábrica em Minnesota. O PulseNet diferenciou os casos associados e a caracterização oportuna do agente promoveu a identificação de casos em estados onde se imaginava que o produto não fora distribuído, totalizando 490 casos em 23 estados. A caracterização por PFGE de isolados de S. Agona foi importante para confirmação do controle do surto pelo retorno do número de isolados a valores esperados e o desaparecimento da cepa associada. (SWAMINATHAN et al. 2001; CDC 2004b).

Profissionais de saúde em Connecticut, Nova lorque, Ohio e Tennessee, registraram aumento de infecções por Listeria. A caracterização por PFGE demonstrou que isolados de casos de diferentes estados apresentaram perfis de bandas indistinguíveis. Investigação adicional revelou 101 casos de infecção cujas bactérias apresentavam o mesmo padrão de bandas ou similares aos identificados em 22 estados. Foram registrados 15 óbitos e 6 abortos ou natimortos. Sanduíches de carne e hot dogs provenientes de instalação de processamento de carne em Michigan 
foram associados aos casos; o surto rapidamente cessou-se após a fábrica recolher os lotes e suspender a produção (SWAMINATHAN et al. 2001).

\subsection{Vigilância de Surtos de DTA}

A maioria dos surtos de DTA consistiam em problemas locais resultantes de práticas de manipulação imprópria associadas a restaurantes ou eventos sociais comunicados aos oficiais de saúde pública locais por telefonemas dos acometidos, que, conhecendo outros individuos que adoeceram após ingerir os mesmos alimentos ou freqüentar o mesmo estabelecimento, provia os oficiais de saúde com as informações necessárias para iniciar a investigação (SWAMINATHAN et al. 2001;TAUXE 2002b; PATRICK et al. 2004).

Atualmente, os surtos de DTA geralmente estão relacionados a produtos alimentícios de ampla distribuição geográfica, com contaminação prévia, resultando em casos envolvendo estados e paises, sendo incomum o conhecimento pelos acometidos de individuos que adoeceram da mesma forma e a capacidade de identificar a possivel fonte de sua infecção. Por estas razões, identificar a exposição comum pelo padrão de bandas gerado por PFGE de isolados de pacientes, tem adquirido importância crescente (SWAMINATHAN et al. 2001; PATRICK et al. 2004).

Para que a vigilância de surtos de DTA seja efetiva, os isolados devem ser subtipados rotineiramente e os dados analisados imediata e localmente. Determinados perfis geralmente podem ser detectados 
localmente, porém não são identificados por métodos epidemiológicos tradicionais de forma isolada. Infecções com um patógeno em comum como Salmonella Typhimurium ocorre com freqüência sugerindo que clusters não são evidentes entre casos aparentemente esporádicos pela utilização de tais métodos. Para os isolados deste agente recebidos pelo laboratório de microbiologia no Departamento de Saúde de Minnesota, a distribuição temporal não sugeriu nenhum perfil específico de forma clara, porém a distribuição dos subtipos por PFGE sugeriu fontes múltiplas comuns com exposições contínuas. A investigação epidemiológica posterior associou três dos subtipos a restaurantes locais, onde a exposição ao agente ocorrera ao longo de um mês. Sem os dados de caracterização, seria complexo associar casos com exposições comuns que ocorrem por períodos prolongados (SWAMINATHAN et al. 2001; CDC 2004b).

Em Setembro de 1998, o LACEN estadual de Minnesota informou os laboratórios do PulseNet que conduzia a investigação de dois perfis de banda para Shigella sonnei associados a restaurantes. O Departamento de Saúde Pública de Los Angeles informou que investigava surtos de infecções pelo agente associados a restaurantes cujos padrões de PFGE das cepas eram muito similares. As investigações epidemiológicas e laboratoriais determinaram que surtos em Massachusetts, Florida e duas provincias Canadenses associavam-se com aqueles. Com o auxilio do FDA, uma salsa importada do México foi identificada como o veículo comum. Autoridades mexicanas e norte-americanas inspecionaram a fazenda cuja salsa era produzida recomendando modificações nas práticas envolvidas para 
prevenir a reincidência do problema. O rápido compartilhamento dos dados de caracterização por PFGE pelo PulseNet foi fundamental para associar os surtos aparentemente não relacionados e identificar o veículo comum (SWAMINATHAN et al. 2001).

\subsection{Pré-requisitos para o Funcionamento Efetivo}

Embora os laboratórios regionais estejam equipados para assistir aos LACEN vizinhos desvinculados ao PulseNet, todos estados devem ter a capacidade de caracterização dos isolados por PFGE. Um indicador importante deste requisito foi o surto de infecção por $E$. coli 0157:H7, veiculado por carne moída no Colorado. Quando o padrão de PFGE foi disponibilizado na rede, laboratórios participantes responderam em menos de 48 horas que não possuiam nenhum padrão semelhante. Porém, foi identificado um caso em Kentucky (desvinculado ao PulseNet) relacionado ao surto de Colorado depois de dois meses. A Associação dos LACEN determinou que a participação na rede é uma capacitação essencial atribuida a todos departamentos de saúde pública nos EUA (SWAMINATHAN et al. 2001).

Para que a rede detecte com eficiência os surtos de DTA pela vigilância de rotina, os laboratórios devem realizar a caracterização por PFGE de E. coli 0157:H7 e L. monocytogenes assim que os isolados são recebidos, bem como para outras bactérias patogênicas como por exemplo: Campylobacter jejuni e C. coli, sorotipos de Salmonella, Shigella spp., 
Bacillus cereus, Vibrio cholerae, V. parahaemolyticus, $V$. vulnificus, Clostridium botulinum, C. perfringens e Yersinia enterocolitica, quando o número de isolados recebidos excederem o número esperado para determinado periodo. Porém, como a vigilância em saúde pública é mais ampla, o PulseNet depende da requisição de cultura de amostras clínicas por médicos em caso de suspeita de infecção bacteriana e do encaminhamento imediato dos isolados pelo laboratório de diagnóstico clínico ao LACEN para tipagem (SWAMINATHAN et al. 2001;TAUXE 2002b)

A cooperação dos laboratórios na tipagem de bactérias patogênicas de origem alimentar seguindo os protocolos padrão permite a comparação de padrões de PFGE de diferentes laboratórios do PulseNet, discernindo quais casos estão associados a um surto específico. Quando um laboratório vinculado ao PulseNet modificou o protocolo para Salmonella Typhimurium e um cluster de casos envolvendo o agente foi detectado neste estado, a análise por PFGE confirmou que muitos isolados eram indistinguiveis, no entanto, ao determinar se o aumento das infecções nas localidades vizinhas relacionava-se ao cluster, os padrões não puderam ser comparados (SWAMINATHAN et al. 2001; PATRICK et al. 2004).

\subsection{Custo-Beneficio}

ELBASHA et al.. (2000) e SWAMINATHAN et al. (2001) compararam os custos e benefícios do sistema de vigilância baseado na caracterização 
molecular do PulseNet utilizando como exemplo as investigações conduzidas pelos LACEN do Colorado em 1997 referentes a um surto de $E$. coli $0157: \mathrm{H} 7$, no qual hambúrgueres congelados foram implicados como veículos do agente. A prevenção de 15 casos pelo recolhimento da carne moída contaminada equivaleria aos custos de cinco anos de operação do sistema PulseNet naquele estado. Estes mesmos autores salientam ainda que se deve considerar os recursos que deixam de ser perdidos em investigações desencadeadas por elevações aparentes de casos esporádicos de infecções pelo agente

\subsection{O Progresso do PulseNet}

Em curto periodo, o PulseNet se desenvolveu além das expectativas e demonstrou sua eficiência como ferramenta para a vigilância de DTA. Iniciou com um patógeno e 10 laboratórios em 1996 que submeteram 191 padrōes de PFGE ao banco de dados durante este ano. Em 1999, quatro patógenos (E. coli O157:H7, Salmonella, Shigella e Listeria monocytogenes) foram acompanhados pelo sistema com mais de 9.500 padrões submetidos ao banco de dados. LACEN estaduais e locais contribuiram com mais de $78 \%$ dos padrões. Como o FDA está aumentando o número de laboratórios que realizam a caracterização por PFGE utilizando os protocolos do PulseNet e o USDA está organizando sua rede local compatível, suas contribuições ao banco intensificará a representação dos padrões de PFGE 
para as bactérias patogênicas isoladas de alimentos (SWAMINATHAN et al. 2001; LINDSAY et al. 2002; WOTEKI e KINEMAN 2003).

A medida que LACEN estaduais e locais se vinculam ao PulseNet, a função dos laboratórios regionais se modifica, provendo treinamento e consultorias aos laboratórios vizinhos, coordenando investigações de surtos de grande amplitude geográfica e proporcionando o aumento da capacitação (SWAMINATHAN et al. 2001;WOTEKI e KINEMAN 2003).

A visão em longo prazo para o PulseNet é uma rede global de LACEN, expandindo a rede por parcerias no México, América do sul e Europa e estreitando suas atividades com as agências regulatórias de alimentos e a indústria para a melhoria da segurança alimentar mundial (SWAMINATHAN et al. 2001; LINDSAY et al. 2002).

Os métodos utilizados para a caracterização e análise de dados devem ser dinâmicos. Há esforços para desenvolver, avaliar e validar constantemente os métodos de caracterização baseados no perfil de bandas para os patógenos de origem alimentar, que serão gradualmente implementados na rede mantendo a compatibilidade em relação aos dados de PFGE existentes. Especialistas em softwares atuam no desenvolvimento de novas versōes dos programas de análise padrão e de comparação dos perfis de forma a aprimorar o pareamento dos padrões (pattern matching) , a normalização automática (automate pattern normalization) e o alinhamento da seqüência (sequence alignment), reduzindo a subjetividade nas comparações (SWAMINATHAN et al. 2001; PATRICK et al. 2004). 
O PulseNet é mantido por recursos do $C D C$ subordinado a Iniciativa Nacional para a Segurança Alimentar (National Food Safety Initiative) e o EIP além de auxilios provenientes de diversos estados e seus respectivos departamentos de saúde pública (SWAMINATHAN et al. 2001;TAUXE 2002b).

\subsection{Foodnet - Vigiláncia Ativa de DTA - Fundamentos e Dados}

Foodnet, segundo WOTEKI e KINEMAN (2003), é um sistema de vigilância ativo de DTA designado para prover informação da incidência desses agravos e prestar-se como estrutura para estudos caso-controle e epidemiológicos.

Segundo PATRICK et al. (2004), a rede é o principal componente relacionado a vigilância de DTA do EIP do $C D C$, e os estudos subsidiados pelos seus dados objetivam preferencialmente $o$ apoio aos oficiais de saúde pública no entendimento da epidemiologia das DTA nos EUA.

Paralelamente ao início do Pulsenet, o $C D C$, cinco departamentos estaduais de saúde e agências regulatórias de alimentos, como parte de uma resposta à emergência de ameaças de doenças infecciosas, implementaram um programa de vigilância ativa para DTA denominado Foodnet, além do Sistema Nacional de Monitoramento da Resistência Antimicrobiana para Enterobactérias (NARMS) (SWAMINATHAN et al. 2001; TAUXE 2002b; PATRICK et al. 2004 ). 
Foodnet é uma rede de nove áreas sentinelas (Califórnia, Colorado, Connecticut, Georgia, Maryland, Minnesota, New York, Oregon e Tennessee) envolvidas em atividades de vigilância ativa para eventos adversos à saúde, geralmente de origem alimentar, incluindo a medida do impacto da doença, determinação das fontes de infecção por estudos casocontrole envolvendo os casos esporádicos e rastreamento do impacto de medidas de controle (TAUXE 2002b; WOTEKI e KINEMAN 2003) .

Dentre os objetivos do FoodNet está o monitoramento da população e a estimativa real e precisa do impacto atribuido às DTA nos EUA, da freqüência e gravidade desses agravos, a investigação de fontes de infecção de surtos e casos esporádicos além da construção de uma infra-estrutura de saúde pública para responder às DTA emergentes (SWAMINATHAN et al. 2001; WOTEKI e KINEMAN 2003; PATRICK et al. 2004).

Além desses objetivos, a Foodnet coleta informaçōes a respeito da ocorrência da síndrome hemolítica urêmica, síndrome Guillain-Barre (conseqüências graves da E.coli O157:H7 e Campylobacter respectivamente) e toxoplasmose (WOTEKI e KINEMAN 2003).

O programa sentinela do $C D C$, Foodnet surgiu com forma de otimizar a identificação de novas DTA. No entanto, essas atividades de vigilância são restritas ao EUA, enquanto que um sistema de informaçōes efetivo para DTA deve possuir amplitude mundial. Cyclospora, por exemplo, foi identificado como um provável patógeno de origem alimentar ou hídrica na Ásia e América do Sul antes do surto ter sido registrado nos EUA (BUCHANAN 1997). 
As informações relacionadas às DTA podem ser adquiridas de diversas fontes: O Programa de Vigilância da Organizaçăo Mundial da Saúde, a rede internacional de investigaçōes laboratoriais e médicas do exército norte americano além da Internet (BUCHANAN 1997).

Segundo TAUXE (2002b), as atividades de vigilância ativa desempenhada pela Foodnet inclui a busca regular, junto aos laboratórios clínicos contemplados pela rede, de informações sobre o que esta sendo diagnosticado, em detrimento da postura passiva de aguardar uma declaração formal dos mesmos.

A Foodnet coleta dados de confirmação laboratorial de sete bactérias (Campylobacter, E.coli 0157:H7, Listeria monocytogenes, Salmonella, Shigella, Vibrio, Yersinia enterocolitica) e dois parasitas (Cyclospora e Cryptosporidium) (WOTEKI e KINEMAN 2003; TAUXE 2002b).

Segundo o $C D C$, os dados do Foodnet apresentam limitaçס̃es intrínsecas; primeiro, o registro atual abrange $13 \%$ da população norte americana, podendo comprometer a representatividade das informaçōes; além disso, os dados provenientes são limitados às doenças confirmadas por laboratório notificadas pela equipe de vigilância. Contudo, grande parte dos individuos acometidos por DTA não são submetidos a testes para determinar o patógeno, e mesmo se a doença for confirmada laboratorialmente, uma fração desconhecida da mesma não é notificada à equipe de vigilância. Além desses aspectos, indivíduos de diferentes faixas etárias podem não ser submetidos a testes com a mesma freqüência: crianças possivelmente sofrem uma busca maior pelo diagnóstico de DTA 
que idosos. Doenças confirmadas laboratorialmente notificadas ao Foodnet podem ser adquiridas por outras rotas de transmissão, como água contaminada, contato pessoa-pessoa e exposição a animais infectados, portanto as taxas registradas podem não representar fontes por alimentos exclusivamente (BUZBY 2002 ;SCHLUNDT 2002).

Dentre os nove patógenos cujas informações são captadas dos laboratórios, Salmonella (não tifóide) apresenta a maior taxa de infecção de adultos com 60 anos ou mais (10.8 casos por 100.000 indivíduos) acompanhada por Campylobacter (9.7 casos por 100.000 indivíduos). As informaçōes referentes a estes patógenos revelam que os mesmos são responsáveis por mais da soma dos casos que envolvem os outros patógenos (BUZBY 2002; PATRICK et al. 2004).

A E.coli 0157:H7 apresenta a terceira maior taxa de infecção em idosos (1.8 casos por 100.000). Os gêneros Shigella e Listeria apresentam praticamente a mesma taxa de infecção considerando este grupo, embora as taxas sejam menores do que aquelas apresentadas por recém nascidos. Shiguelose transmitida por alimento é uma infecção relativamente amena, com uma estimativa de 14 óbitos por ano para todas as faixas etárias. Listeriose é mais severa, com o segundo maior número de óbitos anuais entre os nove patógenos contemplados pelo FoodNet (CDC 2004b)

Segundo dados do FoodNet em relação a incidência de infecções por patógenos transmitidos por alimentos em 2003, um total de 15.600 casos de infecções sob vigilância laboratorialmente diagnosticados foram identificados: 6017 Salmonella, 5215 Campylobacter, 3021 Shigella, 480 
Cryptosporidium, 443 E.coli 0157; 161 Yersinia, 138 Listeria, 110 Vibrio e 15 Cyclospora. Entre as Salmonellas 5455 isoladas foram sorotipadas (91\%), cinco sorotipos representaram 59\% das infecções. Entre os vibrios, em 100 (91\%) foram identificadas as espécies, sendo $46, V$. parahaemolyticus e 16 , V. vulnificus (PINNER et al. 2003; CDC 2004b).

Segundo este relatório, algumas infecçōes afetaram as crianças de forma desproporcional. A incidência de infecção por Salmonella, definida como número de isolados laboratoriais por 100.000 indivíduos, foi de 122.7 para crianças menores de um ano, 50.6 de 1 e 4 anos e 10.8 para indivíduos com cinco anos ou mais. A incidência de infecção por Yersinia foi respectivamente de $9.6,1.4$ e 0.2. Para $E$. coli 0157 os valores foram de 4.5 para crianças de 1 a 4 anos e 0.9 para os demais.

Este relatório revela que a incidência de infecções em 2003 foi menor que a incidência média anual para o período de 1996 a 1998. No entanto, o número de regiões e a população sob vigilância aumentaram desde a sua implantação, confundindo esta comparação. Durante 1996 a 2003, a incidência estimada de diversas infecções declinaram significativamente, dentre elas Yersinia 49\%, E.coli 42\%, Campylobacter 28\%, Salmonella $17 \%$. Para o período de 1997 a 2003 a incidência de infecçōes por Cryptosporidium teve queda de $51 \%$ e por E.coli 0157 apresentou queda no período de 2002 a 2003 (CDC 2004b).

Durante 1996 a 2003, a incidência estimada do sorotipo mais comum de Salmonella, Typhimurim declinou $38 \%$. A incidência do segundo sorotipo mais comum, $S$ Enteritidis, $S$. Newport e $S$. Heidelberg mostrou considerável 
variação segundo ano e não mudou significativamente. A incidência de Salmonella Javiana aumentou $227 \%$ durante o período de 1998 a 2003, grande parte deste aumento ocorreu na Geórgia (CDC 2004b; PATRICK et al. 2004).

A incidência estimada de infecções por Shigella e Listeria revelou considerável variação anual e não se modificou significativamente durante o período de 1996 a 2003. Este documento revela que infecções por Listeria não mantiveram o seu declínio como observado nos últimos quatro anos. Para aquele período, a incidência de infecçōes por Vibrio aumentou $116 \%$ (CDC 2004b).

As modificações na incidência dessas infecções ocorreram no contexto da implementação de medidas de controle pelas agências governamentais e pela indústria de alimentos, intensificando os esforços voltados a educação em segurança alimentar e aumento da atenção de grupos de consumidores e os meios de comunicação. Em 1997, o Department of Agriculture - USDA (EUA) e Safety and Inspection Service FSIS implementaram o Pathogen Reduction/Hazard Analysis and Critical Control Point - HACCP em matadouros de animais e no processamento das carnes. O declinio de infecções humanas por E.coli 0157 em 2003 acompanhou a comunicação pela $F S I S$ que os processadores de produtos derivados de carne moída crua deveriam reavaliar seus planejamentos de APPCC considerando este patógeno, além disso, a produção de carne moida crua não seria distribuida a menos que fossem realizados testes na cadeia de produção. O declínio nas infecçōes por Salmonella no período de 
1996 a 2003 foi acompanhado pela diminuição do isolamento do agente de carnes vermelhas e frango pela FSIS. A FDA também introduziu medidas de intervenção adicionais, incluindo a implementação a APPCC em indústrias de alimentos derivados do mar e em indústrias de sucos, além da publicação de guias de segurança alimentar e normas referentes a refrigeração $e$ rotulagem segura de mariscos (CDC 2004b).

No período de 1996 a 2003, a incidência de infecçōes por Vibrio e Salmonella Javiana aumentaram. A Listeriose declinou após implementação do Listeria Action Plan. Medidas de controle futuras deverão incluir esforços mandatários em fazendas para redução da contaminação de ovos por Salmonella Enteritidis, utilização de carnes moídas pasteurizadas e irradiadas, medidas para a diminuição da prevalência de patógenos em reservatórios animais e de seus derivados: em aves (Salmonella e Campylobacter) gados e carnes moídas (Salmonella e E. coli O157) e frutos do mar, particularmente ostras (Vibrio) e para reduzir a contaminação de produtos agrícolas frescos. A elevada incidência dessas infecções em crianças menores de quatro anos é preocupante, demandando tentativas para determinação de fatores de risco e oportunidades para a sua prevenção (FIDLER 2003; CDC 2004b).

As informaçōes deste relatório estão sujeitas a limitações: Embora a maioria das DTA não seja diagnosticada laboratorialmente, os dados da Foodnet são restritos a doenças diagnosticadas dessa forma, sendo enviesada por fatores que afetam a probabilidade de uma determinada doença ser notificada. As doenças informadas pela Foodnet podem ter sido 
adquiridas por outras fontes que não alimentos, como água contaminada, transmissão pessoa-pessoa e exposição direta a animais. Embora os dados do Foodnet provêm informaçōes detalhadas, estas não podem ser extrapoladas para toda a população norte-americana e finalmente, as mudanças ano a ano podem refletir tanto variações anuais como tendências sustentadas, evidenciando a necessidade de informações adicionais para discernir tendências de forma clara (CDC 2004b).

FoodNet continuará monitorando a ocorrência de DTA. Em 2003, foram conduzidos estudos das repercussões e fatores de risco para doenças causadas por Salmonella Enteritidis, Salmonella Newport, e doenças em crianças causadas por Campylobacter e Salmonella. Dentre outras atividades, cabe citar um projeto para melhorar a coleta e transporte de amostras durante a ocorrência de surtos intensificando a identificação de suas causas. A identificação rápida da causa de casos de diarréia infecciosa e a notificação apropriada às autoridades de saúde pública são fundamentais para identificar e controlar surtos e para uma avaliação precisa da tendência local, regional e norte-americana das DTA de forma a subsidiar os profissionais de saúde em relação às prováveis causas, fontes e fatores prognósticos para os episódios da doença em indivíduos sob seus cuidados (PINNER et al. 2003; CDC 2004b). 


\section{Consideraçס̃es Finais}

No Brasil, a utilização da monitorização das DTA de maneira sistemática e uniforme, da vigilância de base laboratorial e do sistema de notificação compulsória de DTA, além da conexão com sistemas internacionais de informação, pode aprimorar a vigilância e adequá-la aos desafios gerados pela globalização.

O Sistema de Vigilância Epidemiológica das DTA (VEDTA); a Vigilância Ativa em Áreas Sentinelas e Aplicação da Subtipagem Biomolecular; Monitoramentos Ambientais de Patógenos Circulantes $\theta$ outros Contaminantes além do Programa Especial do Controle do Botulismo e ainda o SINAN são iniciativas nacionais importantes considerando o problema das DTA (CVE 2002).

Os sistemas de vigilância de DTA devem ser estruturados não somente em função de casos esporádicos e pequenos surtos, sendo capazes de desencadear investigações de surtos maiores provenientes da contaminação de sistemas de suprimento de alimentos, além disso, é necessário que as funções operacionais das equipes incumbidas da fiscalização e da vigilância epidemiológica sejam bem delimitadas (WETHINGTON e BARTLETT 2004).

A abordagem tradicional de investigação de surtos que executa a coleta de amostras por um único departamento de saúde para a análise microbiológica pode não ser adequada para determinar as características da maioria desses surtos ou identificar seu comportamento ou veículos de transmissão (PETERSEN et al. 2000). 
Investigações de surtos de DTA devem ter a colaboração de universidades e agências govemamentais. Deve-se promover a estabilidade das equipes encarregadas cujo coordenador deve responsabilizar-se pelo controle e divulgação de informações do evento, das ações de intervenção e da elaboração de relatórios.

É necessário que se crie mecanismos para o fortalecimento da pesquisa na área de epidemiologia e laboratório de análise de alimentos integrando a resposta a uma nova ameaça microbiana de origem alimentar, sendo uma chave para que um novo ou reemergente agente biológico deixe de ser desconhecido e para que medidas de controle sejam estabelecidas e multiplicadas (BUCHANAN 1997).

NAJERA (1984) sugere três opções de implementação da pesquisa: ampliaçăo e aprofundamento do conhecimento dos problemas de saúde identificação das causas da desigualdade da aplicação do conhecimento científico e o desenvolvimento de investigaçōes que atinjam os efeitos desejados na saúde.

Segundo WALDMAN (1991), em relação às pesquisas de laboratório e do desenvolvimento tecnológico aplicados às doenças transmissiveis, citam-se áreas de produção do conhecimento: taxonomia de microrganismos, parasitas e vetores, comportamento e biologia de vetores e hospedeiros intermediários de parasitas, identificação de marcadores epidemiológicos, estudos de virulência de microrganismos e parasitas, 
genética microbiana, ecologia e metabolismo de agentes, desenvolvimento da biotecnologia e técnicas padrão e de triagem.

Um programa de pesquisa aplicada às DTA auto sustentável pode ser desenvolvido pela investigação de surto, revelando os problemas de saúde pública indutores de estudos epidemiológicos, investigação inicial focalizada, para responder a problemas especificos, linha de pesquisa abrangente, conduzida por longos períodos (PulseNet) e programa de pesquisa integral, com epidemiologistas especializados com integração da vigilância, laboratório e açōes preventivas (PETERSEN et al. 2000).

É Importante ainda o estabelecimento de articulação entre pesquisa, treinamento e atividades de controle. O suporte à pesquisa é importante quando intervenções de controle para determinadas doenças não existem ou não estão disponíveis (BREMAN e LEDUC 2001).

Para avaliar a compatibilidade organizacional dos laboratórios nacionais com modelo de vigilância representado pela PulseNet, deve-se considerar que o conceito do Sistema Nacional de Laboratórios de Saúde Pública - SISLAB é de um conjunto de redes nacionais de laboratórios, organizadas em sub-redes por agravos ou programas, de forma hierarquizada por grau de complexidade das análises relacionadas à vigilância epidemiológica, vigilância ambiental em saúde, vigilância sanitária e assistência médica (FUNASA 2001).

Em cada rede estruturam-se sub-redes específicas por agravos ou programas, com a identificação dos respectivos laboratórios de referência, área de abrangência e definição de competências. Dessa forma, um 
laboratório pode fazer parte de diversas sub-redes, pois sua inclusão na relação é determinada pela atividade executada e o nivel de complexidade da análise que indicarão sua hierarquização na rede, no padrão de referência nacional, regional, estadual ou municipal (FUNASA 2001).

O novo perfil de hierarquização com conseqüentes modificações nạs áreas de atuação, está voltado para uma maior eficiência e sensibilidade do diagnóstico laboratorial no atendimento às ações de vigilância em saúde, com enfoque direcionado à conformação de sub-redes especificas; priorizando a abordagem por síndromes. Há ainda projetos para implantação das sub-redes de vigilância laboratorial específicas para doenças infecciosas respiratórias, rede de infecções entéricas e meningites dentre outras (FUNASA 2001).

A aplicação de modelos de vigilância como o PulseNet e FoodNet, deve considerar a organização e infra estrutura dos LACEN no Brasil uma vez que os Centros de Controle e Prevenção de Doenças é um modelo de LACEN cujas unidades vinculam-se a um sistema específico de vigilância. A identificação de surtos epidêmicos e a disseminação de cepas para o estudo de agentes infecciosos emergentes são objetivos desse sistema.

Deve-se verificar também que os LACEN estejam aptos a executar suas onze funções essenciais: vigilância, controle e prevenção de doenças, administração integrada de dados, realização de testes referenciais, proteção ambiental, segurança alimentar, aperfeiçoamento e regulação laboratorial, desenvolvimento de políticas, respostas emergenciais, 
pesquisas em saúde pública, educação e treinamento, além de parcerias e comunicação (CDC 2002).

Desafio importante é o reconhecimento e subsídio dos LACEN na execução de funções relacionadas a sua infra-estrutura, como treinamento e desenvolvimento da equipe, inter comunicação, parcerias médicas e hierarquização dos recursos humanos, auxiliando sobretudo na integração ao modelo de vigilância proposto (CDC 2002).

No entanto, a rede de laboratórios nacional, embora venha atendendo às demandas geradas pelos diferentes niveis de gestão do SUS, tem enfrentado dificuldades que se refletem nos aspectos politicos, operacionais e de infra-estrutura. A capacidade instalada não tem recebido, nos últimos anos, investimentos necessários e suficientes que possibilitem o total comprometimento às respostas epidemiológicas geradas por novas necessidades, a exemplo das doenças emergentes e reemergentes, do controle sanitário, de produtos e serviços, oriundas do processo de globalização (FUNASA 2001).

A veiculaçāo da doença por alimento modifica o perfil de comportamento dos surtos de DTA, anteriormente identificados como restritos à instituições como escolas, creches ou residências e eventos comemorativos. Muitos surtos não são detectados, e casos isolados, em regiōes distintas, podem ser componentes de um mesmo surto, não sensíveis aos métodos tradicionais da vigilância epidemiológica, contudo, a utilização de técnicas de biologia molecular, complementares aos dados epidemiológicos, pode contribuir para relacionar casos aparentemente 
isolados e incriminar a fonte alimentar. Os resultados da incorporação da caracterização molecular por PFGE dos agentes das amostras clinicas e dos alimentos associados poderia ser um acréscimo importante para as informações avaliadas (CVE 2002; WETHINGTON e BARTLETT 2004).

O acompanhamento dos casos de DTA utilizando o método molecular de PFGE tem otimizado a identificação da fonte ou veículo de infecção, com a subseqüente remoção de produtos contaminados do sistema de distribuição. A notificação rápida e completa dos casos é um componente fundamental das atividades preventivas de saúde pública (CHANG et al. 2004)

A utilização da caracterização molecular na rotina de vigilância apresenta benefícios que vão além da detecção de surtos, uma vez que casos não relacionados, agregados no tempo ou no espaço ou ainda, no tempo e espaço, não é incomum e sem a utilização de técnicas moleculares, os limitados recursos da saúde pública podem ser desperdiçados na investigação de pseudo surtos. Para que a vigilância de surtos de origem alimentar seja efetiva, os isolados devem ser subtipados rotineiramente e os dados analisados local e imediatamente (SWAMINATHAN et al. 2001).

Segundo estes autores, o suporte laboratorial fornece informação oportuna para os epidemiologistas na investigação de surtos. A caracterização de bactérias patogênicas gera a identificação de surtos não reconhecidos por outros recursos. O uso de métodos padronizados permite que isolados sejam comparados em diferentes regiöes, subsidiando o 
reconhecimento de surtos atribuiveis a uma fonte comum de infecção ao longo de sua extensão.

É pouco comum que doentes conheçam outros que adoeceram ou identifiquem a fonte de infecção tornando-se fundamental a identificação da exposição potencial comum pelo seqüenciamento de DNA dos isolados de pacientes (SWAMINATHAN et al. 2001).

A caracterização molecular é um auxilio à investigação epidemiológica e não deve substituí-la. A observação de que os isolados de dois ou mais indivíduos apresentam padrões de PFGE indistinguiveis não conclui que as pessoas apresentaram uma exposição comum, e sim que os isolados compartilham uma única descendência. Surtos podem ser causados por mais de um subtipo, portanto as diferenças nos padrões de PFGE isoladamente não garantem que os isolados não apresentam uma fonte comum (SWAMINATHAN et al. 2001).

Tradicionalmente o diagnóstico laboratorial centrou-se em métodos de cultura in vitro, acompanhada por testes bioquímicos e sorológicos lentos e variáveis; PFGE é um método de seqüenciamento molecular com um elevado grau discriminatório das cepas de bactérias, além de produzir resultados epidemiológicos significativos (TAUXE 2002b; LIU et al. 2004).

A caracterização de cepas de um microorganismo patogênico em um sistema de base laboratorial e a investigação epidemiológica dos casos esporádicos da doença em geral são abordagens importantes utilizadas pela vigilância em Saúde Publica na identificação de agregados, otimizando a capacidade de detectar surtos dispersos, ampla e geograficamente 
distribuídos, produzindo discernimentos importantes para o desenvolvimento de estratégias de prevenção mais eficazes (TAUXE 2002b).

As técnicas moleculares para detecção, caracterização e enumeração de microrganismos atuam na otimização do estudo de ecossistemas microbiológicos proporcionando perspectivas relacionadas à dinâmica populacional de microrganismos e uma melhor concepção de sua diversidade. Avanços no entendimento dessa dinâmica ecológica são pré requisitos para a garantia da inocuidade dos alimentos (SCHLUNDT 2002).

Os métodos laboratoriais são dinâmicos, novas tecnologias incorporadas pela vigilância podem tornar descobertas recentes, obsoletas, incumbindo aos planejadores a capacidade de garantir a flexibilidade dos sistemas de vigilância de base laboratorial (BEAN e MARTIN 2001).

Novas metodologias de tipagem possivelmente auxiliarão a conexão de casos de surtos amplamente disseminados que poderiam ser considerados casos esporádicos isolados. A discussão das DTA emergentes demandarão atividades de vigilância mais sensíveis e oportunas, intensificando os métodos de identificação e caracterização laboratorial além da identificação de estratégias efetivas de prevenção e controle (SCHLUNDT 2002).

Segundo SWAMINATHAN (2001), um sistema de vigilância de base laboratorial é fundamental para que se detecte um surto de DTA de ampla distribuição geográfica; os agentes são enviados a um laboratório de referência e, por técnicas moleculares, discriminados como pertencentes a um único clone. 
Porém, WETHINGTON e BARTLETT (2004), ressaltam que o sistema de vigilância de base laboratorial atual não aumentará a porcentagem de casos de gastrenterite de rotina já que organizações de seguro saúde limitam o número de amostras submetidas à cultura de casos não complicados. A demora entre a coleta e a sorotipagem é limitação dos sistemas atuais de vigilância passiva, além do longo intervalo entre o início dos sintomas e a conclusão do levantamento de dados da investigação dos casos, impedindo identificação e eliminação oportuna dos alimentos contaminados de forma a prevenir exposições adicionais.

BEAN e MARTIN (2001) destacam a importância de sistemas eletrônicos de vigilância capazes de gerar hipóteses, monitorar tendências e detectar clusters e surtos. A disseminação eletrônica de dados permite que estes objetivos sejam alcançados de maneira oportuna e acurada; sua implementação envolve qualificação da equipe envolvida, políticas de financiamento e de saúde pública.

A transmissão eletrônica de dados é uma importante fonte de informações de patógenos emergentes permitindo o compartilhamento de dados em tempo real reduzindo o intervalo entre a emergência e controle. Limitar as informações às considerações médicas é insuficiente; é preciso incluir conhecimentos dos métodos de produção, condições e práticas de agricultura, medicina veterinária, microbiologia ambiental e da água, tecnologia de alimentos, tendências de consumo e condiçōes sócio econômicas gerais (BUCHANAN 1997; KUUSI et al. 2004). 
A vigilância de DTA em muitos países geralmente é fragmentada, desatualizada, lenta, não padronizada, pouco flexivel e fragilmente integrada em relação às funções laboratoriais e epidemiológicas (BEAN e MARTIN 2001)

A desconexão entre os laboratórios que oferecem apoio ao controle sanitário de produtos de origem animal e vegetal destinados ao consumo humano, vinculados à agricultura e pecuária e o Sistema Nacional de Saúde Pública, evidencia a importância da colaboração daqueles no compartilhamento de informações relevantes para a saúde pública. (WALDMAN e SANTOS 2003; OMS 1962).

Desafio importante, segundo WALDMAN e SANTOS (2003), centra-se no aprimoramento da articulação dos LACEN com a vigilância epidemiológica e a criação de mecanismos que garantam a contínua incorporação de novas tecnologias, como o uso da biologia molecular para identificação de marcadores biológicos associados a determinado comportamento da doença e a incorporação de novas estratégias na utilização da vigilância para o controle de doenças, como os sistemas de vigilância de base laboratorial para DTA.

Segundo SANTOS (1997), o uso do laboratório como fonte de detecção de casos tem sido restrito a algumas doenças, evidenciando a necessidade de um sistema integrado de resultados das análises para diagnóstico das doenças sob vigilância, envolvendo a rede de laboratórios centrais de saúde pública nos estados. 
As DTA permanecem um importante desafio para a saúde pública de diversos países, representando um impacto importante e demandando recursos substanciais para seu controle e prevenção. Novas estratégias de vigilância ativa podem fornecer dados fidedignos de impacto e rastrear tendências na incidência de agravos específicos na medida que ações sofisticadas de prevenção, como o APPCC, são implementadas. (TAUXE 2002b).

É difícil avaliar se as discrepâncias em relação ao subregistro entre países são um reflexo das diferenças reais do desempenho dos sistemas de saúde ou se é decorrente das diferenças metodológicas utilizadas. Diferenças entre as caracteristicas das populaçōes devem ser incluídas nas considerações respectivas à comparação do registro de dados relativos às DTA, por exemplo, diferentes percepções da importância da diarréia como uma doença (SCHLUNDT 2002).

Nos paises em desenvolvimento, os recursos laboratoriais e a qualificação para identificar microrganismos são escassos e a vigilância para etiologias específicas geralmente não é possível. Mesmo em paises desenvolvidos, a vigilância de base laboratorial ainda não é totalmente desenvolvida (SCHLUNDT 2002).

Uma vez apresentadas as novas abordagens da vigilância para as DTA faz-se necessário mencionar a viabilidade de sua implantação no Brasil. Considerando especificamente o modelo de vigilância representado pela PulseNet e os modelos existentes e em implantação no Brasil, notamse, como descrito neste trabalho, algumas iniciativas semelhantes 
protagonizadas pelo CVE e Ministério da Saúde, o que pode ser evidência prática que a implantação de um modelo semelhante é factível, considerando os avanços recentes principalmente no tocante à capacitação de recursos humanos proporcionada pelos programas de treinamento.

A vigilância de perigos e do sistema APPCC devem ser aplicados de forma sistemática no país, e para que se enriqueça cientificamente a segurança alimentar, a aplicação da análise de risco torna-se fundamental. A MP, por sua vez, é uma ferramenta importante para aprimorar o planejamento do sistema de segurança relacionado ao suprimento de alimentos.

A melhor articulação das agências envolvidas no processo regulatório da segurança alimentar, a incumbência pela garantia da segurança alimentar desde o início do processo produtivo e a rapidez na aprovação de tecnologias podem otimizar a utilização desses instrumentos.

O aumento expressivo das DTA é multifatorial e o controle de muitos desses fatores é um desafio para as autoridades de saúde pública. Para que se aprimore as ações de controle e prevenção, adequando o sistema de vigilância à essas transformações, novas abordagens da vigilância são necessárias.

As DTA constituem importante problema de saúde pública de países em desenvolvimento e industrializados; sua multicausalidade, intrínseca aos modelos de desenvolvimento econômico, demanda abordagens multidisciplinares no estabelecimento de estratégias para o seu controle e a 
aplicação experimental de modelos de vigilância, cujos resultados têm-se revelado satisfatórios.

O Brasil consolida-se como nação exportadora de alimentos. Esforços devem ser enfocados para a aplicação da rastreabilidade e adoção das Boas Práticas de Produção Animal e Agrícola, protegendo e regulamentando o mercado pela atualização contínua de sua legislação segundo especificações e exigências do comércio internacional.

O sistema de segurança alimentar do Brasil deve apresentar uma definição clara e objetiva de seus principios, produzir conhecimento pelas parcerias com agências internacionais, fortalecer a pesquisa, sobretudo na área de epidemiologia e laboratório de análise de alimentos, desenvolver programas de formação, capacitação e sistemas de vigilância segundo experiências de países desenvolvidos adaptadas à sua realidade, além de aprimorar continuamente sua legislação.

Diante do aumento da importância das DTA e da complexidade dos fatores causais a elas associados como as mudanças ocorridas na sociedade brasileira nos últimos 20 anos, consolidando-se predominantemente como urbana e industrializada, com expressivo desenvolvimento da agroindústria e aumento do consumo de alimentos industrializados, tornou-se indispensável a criação de infra-estrutura e de recursos humanos qualificados, paralelamente à aplicação de tecnologia adequada em todos os niveis da cadeia produtiva, regulamentação atualizada e organização de um sistema de inteligência que detecte com 
sensibilidade satisfatória a quebra da qualidade desses produtos, garantindo a segurança dos alimentos e prevenindo prejuizos a saúde humana. 


\section{Referências}

Alencar LCM. Vigilância e controle das doenças transmitidas por alimentos. São Paulo; 2002. [Tese de Mestrado_Faculdade de Saúde Pública da USP].

Almeida MLP. Como elaborar monografias. $4^{\circ}$ ed. Belém: CEJUP, 1996. $211 p$.

Altekruse SF, Cohen ML, Swerdlav D. Emerging foodborne diseases. Emerging Infectious Diseases 1997;3(3):285-93.

Armitage $\mathrm{NH}$. Use of predictive microbiology in meat hygiene regulatory activity. International Journal of Food Microbiology 1997;36:103-109.

Balter S, Benin A, Pinto SWL, Teixeira LM, Alvim GG, Luna W, Jackson D, LaClaire L, Elliott J, Facklam R, Shuchat A. Epidemic nephritis in Nova Serrana, Brazil. The Lancet 2000. 355:1776-1780.

Bean NH e Martin SM. Implementing a network for electronic surveillance reporting from public health reference laboratories: a international perspective. Emerging Infectious Diseases 2001; 7(5) 773-779.

Borgdorff MW e Motarjemi Y. Surveillance of foodborne diseases: what are the options ?. World Health Stat Q 1997;50(1-2):3-4.

Brasil. Ministério da Saúde. Agencia Nacional de Vigilância Sanitária ANVISA. Açōes fiscais realizadas pelos órgaos de vigilância sanitária. Informe técnico [online].Disponivelem<URL:

a dez 20]. 
Brasil. Ministério da Saúde. Agencia Nacional de Vigilância Sanitária ANVISA. Notícias da Anvisa. Boletim Eletrônico [online].. Disponivel em <URL: $>$ jan 2004b ].

Brasil. Ministério da Saúde. Secretaria de Vigilância em Saúde. Doenças infecciosas e parasitárias. Guia de bolso. $3^{\circ}$ ed. Brasilia:2004c (1): $235 p$.

Brasil. Portaria n 710 de 10 de junho de 1999. Aprova a Política Nacional de Alimentação e Nutrição 1999. Agência Nacional de Vigilância Sanitária. Disponível em <URL:http://www.anvisa.gov.br/alimentos/alimentos/legis/geral.htm>[2002 jun 05]

Brasil .Portaria no 1.943, de 18 de outubro de 2001. Define a relação de doenças de notificação compulsória para todo território nacional. 2001a. Disponível em <URL: http://www.funasa.gov.br/legis/legis00.htm> [2002 jun 05]

Breese J, Fang ZY, Wang B, Nelson EAS, Tam J, Soenarto Y, Wilopo SA, Kilgore P, Kim JS, Kang JO, Lan WS, Gaik CL, Moe K, Chen KT, Jiraphongsa C, Pongsuwanna Y, Man NV, Tu PV, Luan LT, Hummelman E, Gentsch JR, Glass R. First report from the asian rotavirus surveillance network. Emerging Infectious Diseases 2004;10(6):988-995.

Breman J, Leduc J. International partnerships in infectious diseases research, training and control. Emerging Infectious Diseases 2001;7(3):542543.

Buchanan RL. Identifying and controlling emerging foodborne pathogens: research needs. Emerging Infectious Diseases 1997; (4):517-21. 
Buehler JW, Berkelman RL, Hartley DV, Peters CJ. Syndromic surveillance and bioterrorism-related epidemics [letter]. Emerging Infectious Diseases 2003;9:1197-1204

Buzby JC. Older adults at risk of complications from microbial foodborne illness. FoodReview 2002;25(2) 30-35.

Centers for Disease Control and Prevention. Building epidemiology capacity. MMWR 2003; 52 (43):1037-1064.

Centers for Disease Control and Prevention. Core functions and capabilities of State Public Health Laboratories. MMWR 2002; 51 (14):1-8.

Centers for Disease Control and Prevention. Diagnosis and management of foodborne illness. A primer for physicians and other health care profissionals. MMWR 2004a; 53 (RR-4):1-33.

Centers for Disease Control and Prevention. Enhanced detection of sporadic Escherichia coli O157:H7 infecitions--New Jersey, July 1994. MMWR 1995; 44(22):417-8.

Centers for Disease Control and Prevention. Foodborne Diseases Active Surveillance Network (FoodNet). 2001 Available from $<$ URL:http://www.cdc.gov/foodnets[2001 Dez 06].

Centers for Disease Control and Prevention. Foodborne hepatitis A Missouri, Wisconsin, and Alaska, 1990-1992. MMWR 1993;42(27):526-529.

Centers for Disease Control and Prevention. Preliminary FoodNet data on the incidence of foodborne illnesses-selected sites, United States, 2000. MMWR 2001;50(13):241-6. 
Centers for Disease Control and Prevention. Preliminary Foodnet data on the incidence of infection with pathogens transmitted commonly through food selected sites, United States, 2003. MMWR 2004b;53(16):338-343.

Centers for Disease Control and Prevention. Surveillance for foodbornedisease outbreaks - United States, 1993 -1997. MMWR 2000; 49 (SS-1):1-72.

Centers for Disease Control and Prevention. System descriptions New York city syndromic surveillance systems. MMWR 2004c;53:23-27.

Centro Latino-Americano de Perinatologia e Desenvolvimento Humano (CLAP) - OPAS/OMS, Montevidéu. Saúde perinatal. Trad. Thais de Azevedo. Brasil 1988. Tradução de artigos selecionados de Salud Perinatal, boletim do CLAP;179p.

Chang HH, Tserenpuntsag B, Kacica M, Smith PF, Morse DL. Hemolytic Uremic Syndrome incidence in New York. Emerging Infectious Diseases 2004. 10(5) 928-931.

Collins JE. Impact of changing consumer lifestyles on the emergence/reemergence of foodborne pathogens. Emerging Infectious Diseases 1997 4(3):471-479.

Conference report. The international conference on bovine spongiform encephalopathy and food safety, April 17-18, 2002.Food Control 2004; 15 : 71-77.

Dembek ZF, Cochrane DG, Pavlin JA. Syndromic Surveillance. Emerging Infectious Diseases 2004;10(7):1333-1335.

DeWall CS. Safe food from a consumer perspective. Food Control 2003; 14:75-79. 
Fidler DP. Globalization, international law, and emerging infectious diseases. Emerging Infectious Diseases 1996;2(2):78-84.

Fidler DP. Legal challenges posed by the use of antimicrobials in food animal production. Microbes and Infection 1999;(1):29-38.

Fidler DP. Emerging trends in international law concerning global infectious disease control. Emerging Infectious Diseases 2003;9(3):285-290

Frenzen PD. Deaths due to unknown foodborne agents. Emerging Infectious Diseases 2004; 10 (9):398-403.

FUNASA. Ministério da Saúde. Reestruturação do Sistema Nacional de Laboratórios de Saúde Publica 2001. Disponivel em <URL: http://dtr2001.saude.gov.br/svs/epi/epi00.htm> [2005 jan 21].

Germano PML, Germano MIS. Higiene e vigilância sanitária de alimentos, qualidade das matérias primas, doenças transmitidas por alimentos, treinamento de recursos humanos. $2^{\mathrm{a}}$ ed. São Paulo: Varela, 2003. 655p.

Gill CJ, Keene WE, Mohle-Boetani JC, Farrar JA, Waller PL, Hah CG, Cieslak PR. Alfalfa seed decontamination in a salmonella outbreak. Emerging Infectious Diseases 2003;9(4):474-478.

Giovannini A, Prencipe V, Conte A, Marino L, Petrini A, Pomilio F, Rizzi V, Migliorati G. Quantitative risk assessment of Salmonella spp. Infection for the consumer of pork products in an Italian region. Food Control 2004;15:139144.

Grande E. La fiscalización. In: Medicina y salud pública. Mazzáfero VE (ed).. Buenos Aires: Eudeba, 1999. 
Greeg MB. Field Epidemiology. $2^{\text {nd }}$ edition New York. Oxford University Press. 2002.

Guzewich JJ, Bryan FL, Todd ECD. Surveillance of foodbome disease I. Purposes and types of surveillance systems and networks, Journal of Food Protection 1977;(60):555-66.

Heffernan R, Mostashari F, Das D, Karpati A, Kulldorff M, Weiss D. Syndromic surveillance in public health practice, New York City. Emerging Infectious Diseases 2004;10(5):858-864.

Hoornstra E, Notermans S. The use of quantitative risk assessment in HACCP. Food Control 2001;12:229-234.

Hughes JM. Emerging Infectious diseases: A CDC perspective. Emerging Infectious Diseases 2001;7(3):494-96.

Hulley SB. Delineando a pesquisa clínica. Uma abordagem epidemiológica. $2^{a}$ ed. Porto Alegre: ARTMED, 2003. 373p.

lovine MN, Blaser MJ. Antibiotics in animal feed and spread of resistant campylobacter from poultry to humans. Emerging Infectious Diseases 2004;10(6):1158-1159.

Jones TF, Buckingham SC, Bopp CA, Ribot E, Schaffner W. From pig to pacifier: chitterling-associated Yersiniosis outbreak among black infants. Emerging Infectious Diseases 2003;9(8):1007-1009.

Jones TF, Pavlin BI, LaFleur BJ, Ingram LA, Schaffner W. Restaurant inspection scores and foodborne disease. Emerging Infectious Diseases 2004;10(4):688-92. 
Kaku M, Peresi JTM, Tavechio AT, Fernandes SA, Batista AB, Castanheira IAZ, Garcia GMP, Irino K, Gelli DS. Surto alimentar por salmonella enteritidis no noroeste do Estado de São Paulo, Brasil. Revista de Saúde Pública $1995 ; 29(2): 127-31$.

Kaferstein FK. Actions to reverse the upward curve of foodborne illness. Food Control 2003;(14):101-109.

Kaferstein FK. Food safety: a commonly underestimated public health issue. Introduction. World Health Stat Q 1997;50 (1-2): 3-4.

Kimura AC, Johnson K, Palumbo MS, Hopkins J, Boase JC, Reporter R, Goldoft M, Stefonek KR, Farrar JA, Gilder TJV, Vugia DJ. Multistate Shigellosis outbreak and commercially prepared food, United States. Emerging Infectious Diseases 2004; 10(6):1147-1149.

Koopmans $M$, Vennema $H$, Heersma $H$, Strien $E$, Duynhoven $Y$, Brown D, Reacher M, Lopman B. Early identification of common-source foodborne virus outbreaks in Europe. Emerging Infectious Diseases 2003; 9(9):11361142.

Kuusi M, Nuorti JP, Maunula L, Miettinen I, Pesonen H, Bonsdorff CV. Internet use and epidemiologic investigation of gastroenteritis outbreak. Emerging Infectious Diseases 2004;10(3):447-450.

Kvenberg J, Stolfa P, Stringfellow D, Garrett ES. HACCP development and regulatory assessment in the United States of America. Food Control 2000;11:387-401.

Langmuir AD. The surveillance of communicable diseases of national importance. The New England Journal of Medicine 1963; 268 (4)182-192. 
Langmuir $A D$ e Andrews JM. Biological warfare defense. The epidemic intelligence service of the communicable disease center. American Journal of Public Health 1952; 42: 235-238.

Legnani P, Leoni E, Berveglieri M, Mirolo G, Alvaro N. Hygienic control of mass catering establishments, microbiological monitoring of food and equipment. Food Control 2004;15:205-211.

Lindsay EA, Lawson AJ, Walker RA, Ward LR, Smith HR, Scott FW, O'Brien SJ, Fisher IST, Crook PD, Wilson D, Brown DJ, Hardardottir H, Wannet WJB, Tschape $\mathrm{H}$, Threlfall EJ . Role of electronic data exchange in an international outbreak caused by Salmonella enterica serotype Typhimurium DT204b. Emerging Infectious Diseases 2002; 8(7):732-734.

Liu D, Ainsworth AJ, Austin FW, Lawrence ML. Use of PCR primers derived from a putative transcriptional regulator gene for species-specific determination of Listeria monocytogenes. International Journal of Food Microbiology 2004;91:297-304.

Loonsk JW. BioSense: A National initiative for early detection and quantification of public health emergencies. MMWR 2004;53:53-55.

Majkowski J. Strategies for rapid response to emerging foodborne microbial hazards. Emerging Infectious Diseases 1997;4(3):551-554.

Mayes T. Risk analysis in HACCP: burden or benefit ?. Food Control 1998; 9(2-3):171-176.

McDonald K. Predictive food microbiology for the meat industry: a review. International Journal of Food Microbiology 1999;52(1-2):1-27. 
McLauchlin J, Mitchell RT, Smerdon WJ, Jewell K. Listeria monocytogenes and listeriosis: a review of hazard characterization for use in microbiological risk assessment of foods. International Journal of Food Microbiology 2004; 92:15-33.

Mead PS, Slutsker L, Dietz V, McCaig LF, Bresee JS, Shapiro C, Griffin PM, Tauxe RV. Food-Related IIIness and Death in the United States. Emerging Infectious Diseases 1999;5(5):607-625

Meng J, Doyle MP. Introduction. Microbiological food safety. Microbes and Infection 2002; (4): 395-7.

Miyagishima K, Moy G, Miyagawa S, Motarjemi Y, Käferstein FK. Food safety and public health. Food Control 1995; 6(5): 253-259.

Morris JG Jr, Potter M. Emergence of new pathogens as a function of changes in host susceptibility. Emerg Infect Dis 1997;3(4):435-41.

Morse SS, Hughes JM. Developing an integrated epidemiologic approach to emerging infectious diseases. Epidemiol Rev 1996;18(1):1-3.

Motarjemi Y, Kaferstein F. Food safety, hazard analysis and critical control point and the increase in foodborne diseases: a paradox $i$. Food Control 1999; 10: 325-333.

Najera E. Usos y perspectivas de la epidemiologia en la investigacion. In: Organizacion Panamericana de la salud. Usos e perspectivas de la epidemiologia: documentos de Seminário. Washington, D.C.,1984 p 109129. 
OPAS/INPPAZ. Guia de Sistemas de Vigilância das Enfermidades Transmitidas por Alimentos e a Investigação de Surtos (GUIAVETA).Buenos Aires,Argentina. 2001.207p.

Orriss GD, Whitehead AJ. Hazard analysis and critical control point (HACCP) as a part of an overall quality assurance system in international food trade. Food Control 2000; (11): 345-351.

Patrick ME, Adcock PN, Gomez TM, Altekruse SF, Holland BH, Tauxe RV, Swerdlow DL. Salmonella Enteritidis infections, United States, 1985-1999. Emerging Infectious Diseases 2004;10(1):1-7.

Peresi JTM, Almeida IAZC, Lima SI, Marques DF, Rodrigues ECA, Fernandes SA, Gelli DS, Irino K. Surtos de enfermidades transmitidas por alimentos causados por Salmonella Enteritidis. Revista de Saúde Pública 1998; 32(5):477-83.

Petersen LR, Ammon A, Hamouda O, Breuer T, KieBling S, Bellach B, Niemer $U$, Bindert FJ, Ostroff $S$, Kurth R. Developing national epidemiologic capacity to meet the challenges of emerging infections in germany. Emerging Infectious Diseases 2000;6(6):576-84.

Pinner RW, Rebmann CA, Schuchat A, Hughes M. Disease surveillance and the academic, clinical and public health communities. Emerging Infectious Diseases 2003; 9(7) 781-87.

Potter ME, Tauxe RV. Epidemiology of foodborne diseases: tools and aplications World Health Stat Q 1997;(50):24-29.

Reingold AL. Outbreak investigations - a perspective. Emerging Infectious Diseases 1998; 4(1) 21-27. 
Rodrigues LC e Werneck GL. Estudos caso-controle in Medronho RA. Epidemiologia. São Paulo: Atheneu.2002

Rothman KJ. Clustering of disease. American Journal of Public Health 1987;77:13-15

Rouqaryol MZ, Filho NA. Epidemiologia e Saúde. $6^{\circ}$ ed. Rio de Janeiro: MEDSI, 2003. 708p.

Santos AR. A rede laboratorial de saúde pública e o SUS. Informe Epidemiológico do SUS 1997;2 (VI):7-14.

Sauders BD, Fortes ED, Morse DL, Dumas N, Kiehlbauch JA, Schukken Y, Hibbs JR, Wiedmann M. Molecular subtyping to detec human listeriosis clusters. Emerging Infectious Diseases 200;9(6):672-680.

Schlundt J. New directions in foodborne disease prevention. Internacional Journal of Food Microbiology 2002;(78):3-17.

Schuchat A, Hilger T, Zell E, Farley MM, Reingold A, Harrison L, Lefkowitz L, Danila R, Stefonek K, Barret N, Morse D, Pinner R. Active bacterial core surveillance of the emerging infections program network. Emerging Infectious Diseases 2001;7(1):92-99.

Secretaria de Estado da Saúde. Centro de Vigilância Sanitária (CVS): Prevenção da cólera: vigiläncia sanitária em serviços de saúde, manual de procedimentos. São Paulo. 1991: 31p.

Secretaria de Estado da Saúde de São Paulo. Centro de Vigilância Epidemiológica (1). Vigilância ativa: doenças transmitidas por alimentos; normas e instruções. São Paulo; 2002. Disponível em <http://www.cve.saude.sp.gov.br>[2003 ago 28]. 
Secretaria de Estado da Saúde de São Paulo. Centro de Vigilância Epidemiológica (CVE). Projeto intersetorial de vigilância das DTA e águaDTA.SãoPaulo.1999. Disponivel em <http://www.cve.saude.sp.gov.br>[2003 ago 25].

Secretaria Municipal de Saúde (SMS). Boletim Saúde São Paulo. N²9, Set. 2004, p.1-8.

Eduardo MBP, Katsuya EM, Campos JC, Mello MLR, Conde MTRP, Bassit MP, Kitagawa BY. II simpósio de segurança alimentar e saúde - II simpósio de vigilância das doenças de transmissão hídrica e alimentar - 1 amostra estadual de vigilância das doenças de transmissão hídrica e alimentar $e$ segurança de alimentos. Boletim Informativo. CVE-SES/SP. São Paulo. Ano 17 , No 60 , Set. 2002, p. 6-12.

Sichel LS, Greenko J, Heffernan R, Weiss D. Field investigations of emergency department syndromic surveillance signals, New York City. Emerging Infectious Diseases 2004;10(7):1333-1335.

Smith JL. Foodbome infections during pregnancy. J Food Prot 1999 ;62(7):818-29

Swaminathan B, Barrett TJ, Hunter SB, Tauxe RV. Pulsenet: the molecular subtyping network for foodborne bacterial disease surveillance, United States. Emerging Infectious Diseases 2001; (7): 382-9

Taormina PJ, Beuchat LR, Slutsker L. Infections associated with eating seed sprouts: an international concern. Emerging Infectious Diseases 1999;5(5):626-632. 
Tauxe RV. Emerging foodborne disease: An Evolving Public Health Challenge. Emerging Infectious Diseases 1997; 167(6):1330-1335.

Tauxe RV. Emerging foodborne pathogens. International Journal of Food Microbiology 2002a; (78): 31-41.

Tauxe RV, Hughes JM. International investigations of outbreaks of foodborne disease: public health responds to the globalization of food. BMJ 1996; (313):1093-94.

Tauxe RV. Surveillance and investigation of foodborne diseases; roles for public health in meeting objectives of food safety. Food Control 2002b;(13):363-369.

Tauxe RV, Vandepitte J, Wauters G, Martin SM, Goossens V, De Mol P. Yersinia enterocolitica infections na pork: the missing link. The Lancet.1987:1129-1132

Teixeira MG, Junior JBR, Costa MCN. Vigilância epidemiológica in Rouqaryol MZ, Filho NA. Epidemiologia e Saúde. $6^{\circ}$ ed. Rio de Janeiro: MEDSI; 2003 p:313-356

Vaclavik VA. Food safety. In: Essentials of food science. Aspen: Gaithersburg, 1998 . p.295-326.

Van de Venter T. Emerging food-borne diseases: a global responsibility. FAOMHO Food Nutrition and Agriculture 2000; 4-13. Available from <URL: http://www.fao.org/DOCREP/003/X7133M/x7133m00.htm\#TopOfPage $>[2002$ Jan 11]. 
Vanne L, Karwoski M, Sjoberg AM. HACCP-based food quality control and rapid detection methods for microorganisms 1996. Food Control 1996;6 (7): 263-276.

Vogt RL, LaRue D, Klaucke DN, Jillson DA. Comparison of an active and passive surveillance system of primary care providers for hepatitis, measles, rubella, and salmonellosis in Vermont. American Journal of Public Health 1983; 73 (7) 795-797.

Waldman EA, Rosa TEC. Vigilância em saúde pública. F. Petrópolis: São Paulo, 1998.

Waldman E, Santos AR. Laboratórios de saúde pública in Rouqaryol MZ, Filho NA. Epidemiologia e Saúde. 6a ed. Rio de Janeiro: MEDSI; 2003. p:629-647.

Waldman E. Vigilância Epidemiológica como prática de saúde pública. São Paulo; 1991. [Tese de_Doutorado_Faculdade de Saúde Pública da USP].

Walls I e Scott VN. Use of predictive microbiology in microbial food safety risk. International Journal of Food Microbiology 1997;36:97-102.

Wethington $H$, Bartlett $P$. The Rusick2 foodborne disease forum for syndromic surveillance. Emerging Infectious Diseases 2004; 10(3):401-405.

Whiting RC. Microbial modeling. Food Technology 1997; 48(6):113-120.

Woteki CE, Kineman BD. Challenges and approaches to reducing foodborne illness. Annu. Rev. Nutr. 2003; 23: 315-44.

Yuan CM, Love S, Wilson M. Syndromic surveillance at hospital emergency departments - southeastern Virginia. MMWR 2004;53:56-58. 
Anexos 


\section{Anexo 1}

Ficha de investigação de surto de DTA

\begin{tabular}{|l|l|l|}
\hline $\begin{array}{l}\text { 1. Onde ocorreu o surto? (local) } \\
\text { Estado Cidade } \\
\text { Municipio }\end{array}$ & & 2. Data do primeiro caso (dt1caso) \\
\hline 3. Indicar números precisos ou aproximados & 4. Histórico de exposiçáo & \\
\hline Individuos expostos & $\mathrm{N}^{\circ}$ obtido & 5. Periodo de Incubaçăo(horas) \\
\hline Individuos doentes & $\mathrm{N}^{\circ}$ de individuos com sintomas & Menor \\
\hline Hospitalizados & Náusea $\quad$ Diarréia & Aproximado (maioria) \\
\hline Obitos & Vómitos $\quad$ Febre & 6.Duraçăo da doença (horas) \\
\hline & Cólicas & Menor Maior \\
\hline 7.Alimento - taxas de ataque especificas: & & Aproximado (maioria) \\
\hline
\end{tabular}

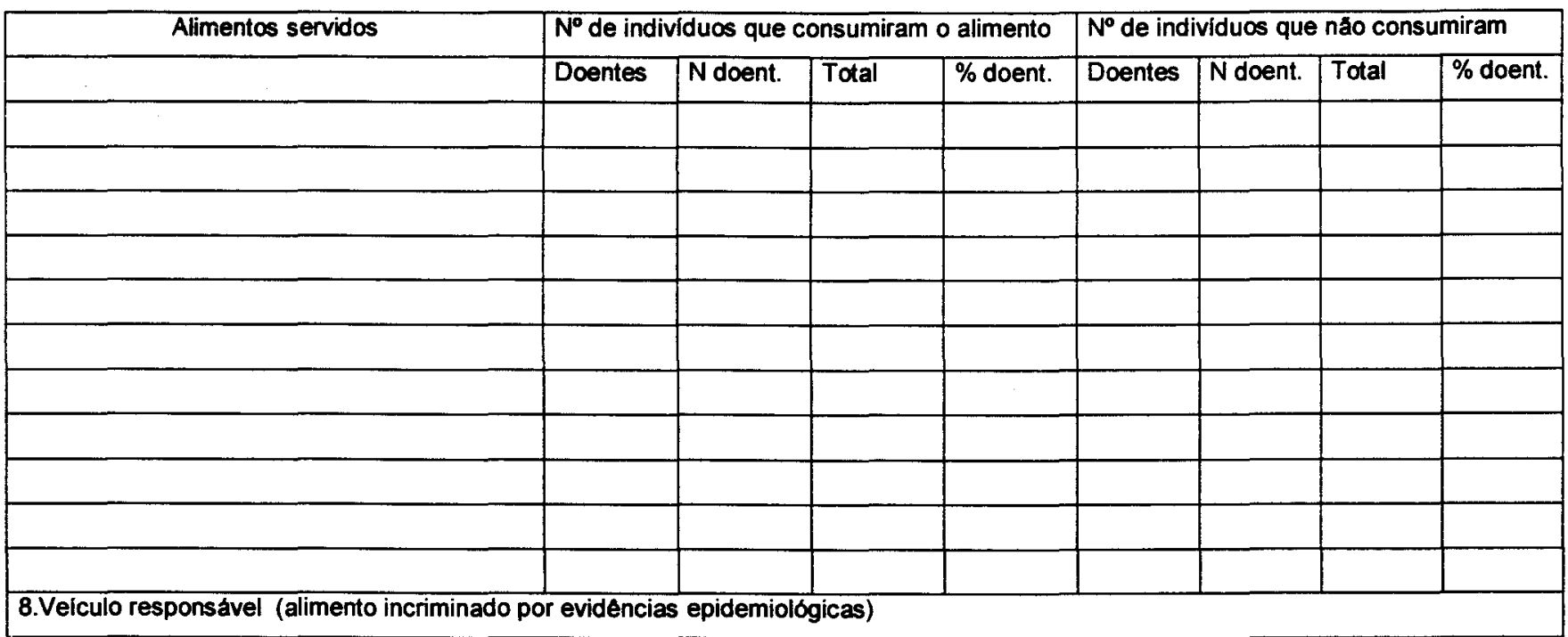

\begin{tabular}{|c|c|c|c|}
\hline \multicolumn{2}{|c|}{ 9. Modo pelo qual o alimento foi negociado } & 10. Local de preparo & 11. Local consumido \\
\hline Industria Alimentar & Sem embalagem & Restaurante & Restaurante \\
\hline Cru & Embalagem usual & Casa de comidas finas & Casa de comidas finas \\
\hline Processado & Enlatado & Cafeteria & Cafeteria \\
\hline Caseiro & Enlatado a vácuo & Casa & Casa \\
\hline Cru & Outro & Fornecedor & Fornecedor \\
\hline \multicolumn{4}{|l|}{ Processado } \\
\hline & Temperatura ambiente & Instituiçăo & Instituiçăo \\
\hline & Refrigerador & Escola & Escola \\
\hline & Freezer & Igreja & Igreja \\
\hline & Aquecido & Acampamento & Acampamento \\
\hline & & Outros & Outros \\
\hline Produto comercial: indi & & & \\
\hline
\end{tabular}

Fonte: Center for Disease Control and Prevention - CDC Form 52.13 adaptado 


\section{Anexo 1}

\section{Ficha de investigação de surto de DTA (cont.)}

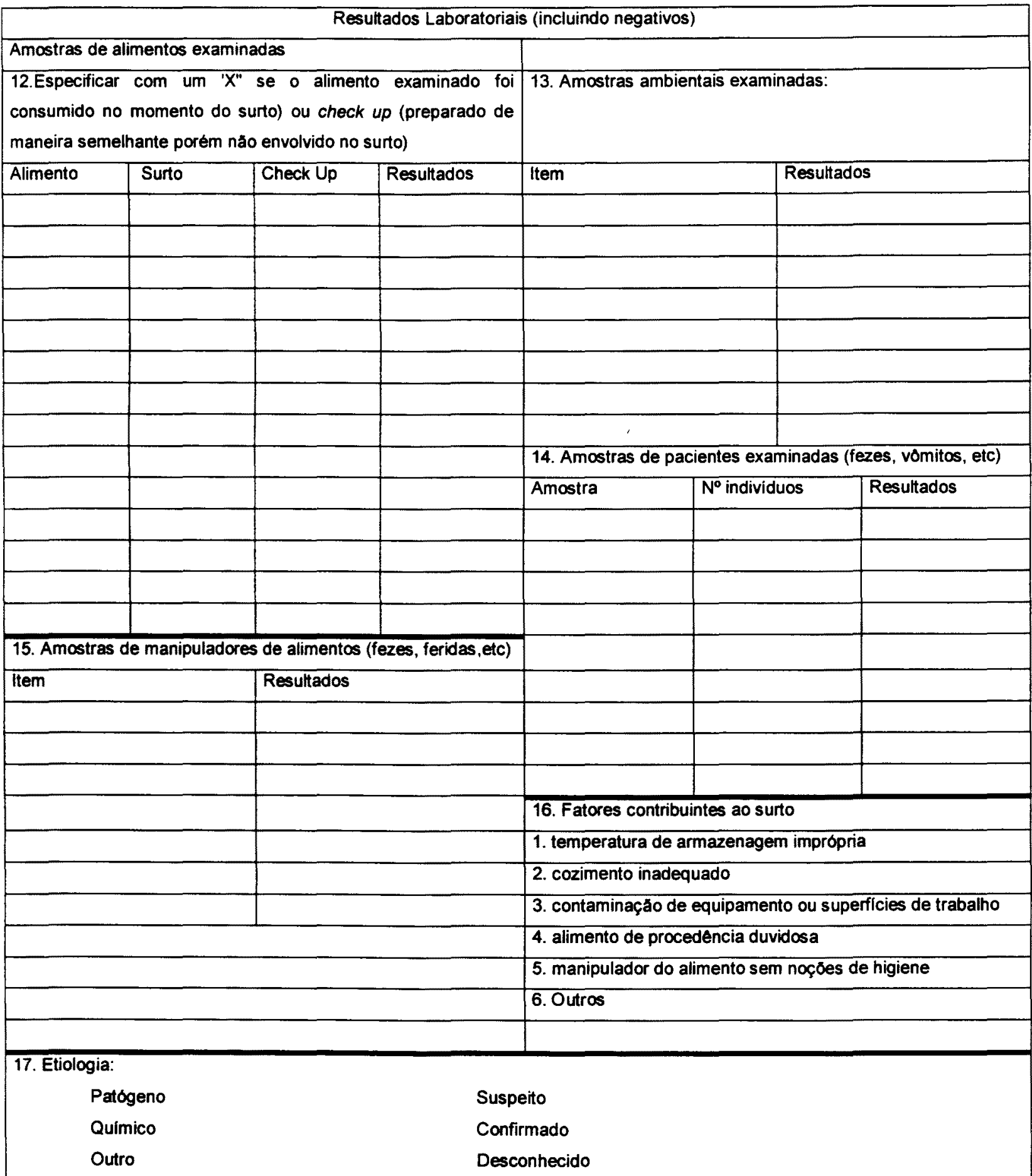

18. descriçăo de aspectos da investigaçăo năo contemplados acima, tais como distribuiçăo por sexo e etária nấo usual: circunstancias atipicas que levaram a contaminaçăo de alimentos, água, curva epidémica

Agencia notificante:

Investigador:

| Data de investigaçăo:

Fonte: Center for Disease Control and Prevention - CDC Form 52.13 adaptado 


\section{Anexo 2}

\section{Resumo das Informações Obtidas dos Questionários de Investigação do Surto}

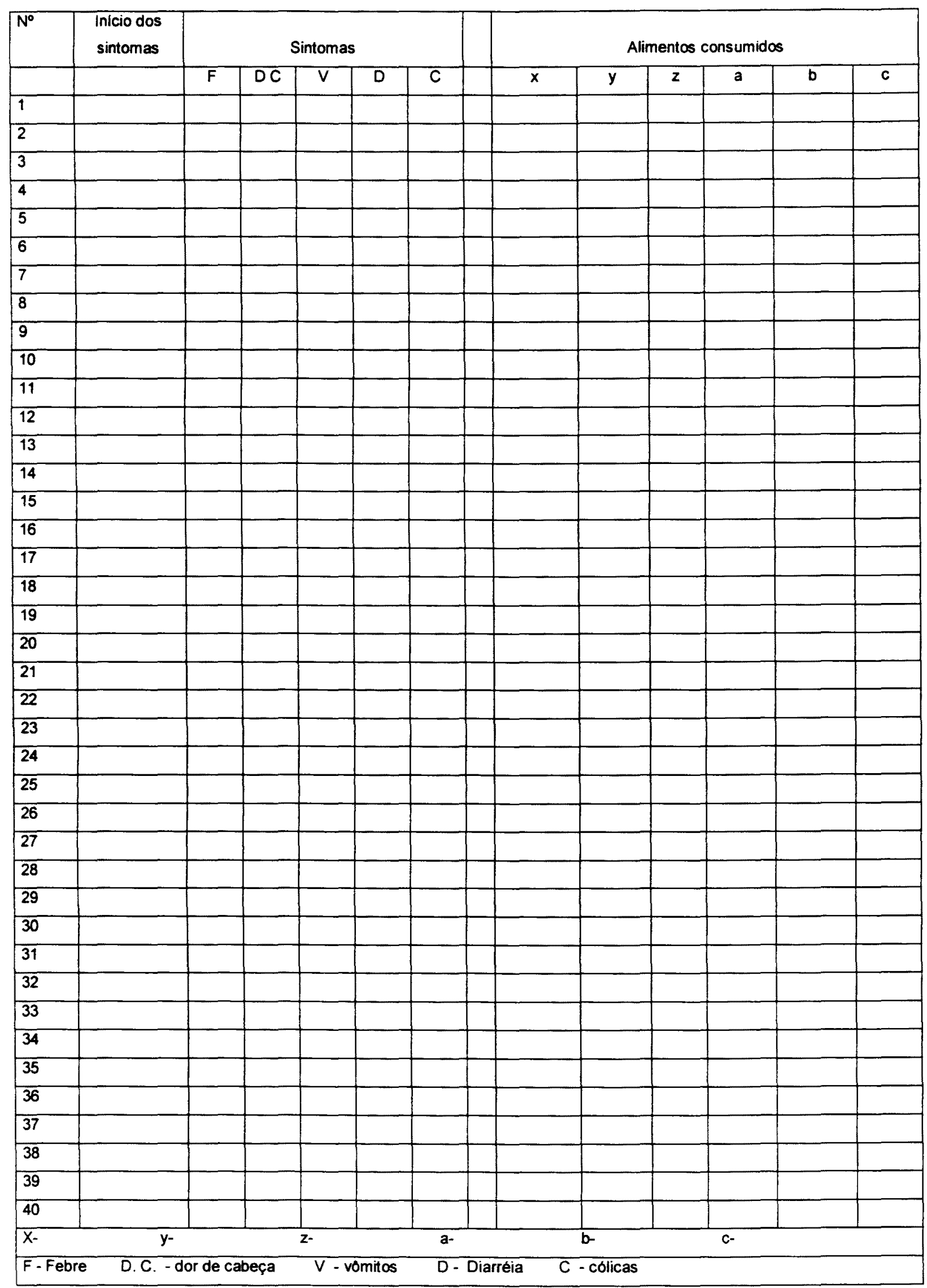

Fonte: Center for Disease Control and Prevention - CDC Form 52.13 adaptado 


\section{Anexo 3}

\section{Ficha de Investigação de Surto de DTA II}

Caso

Controle

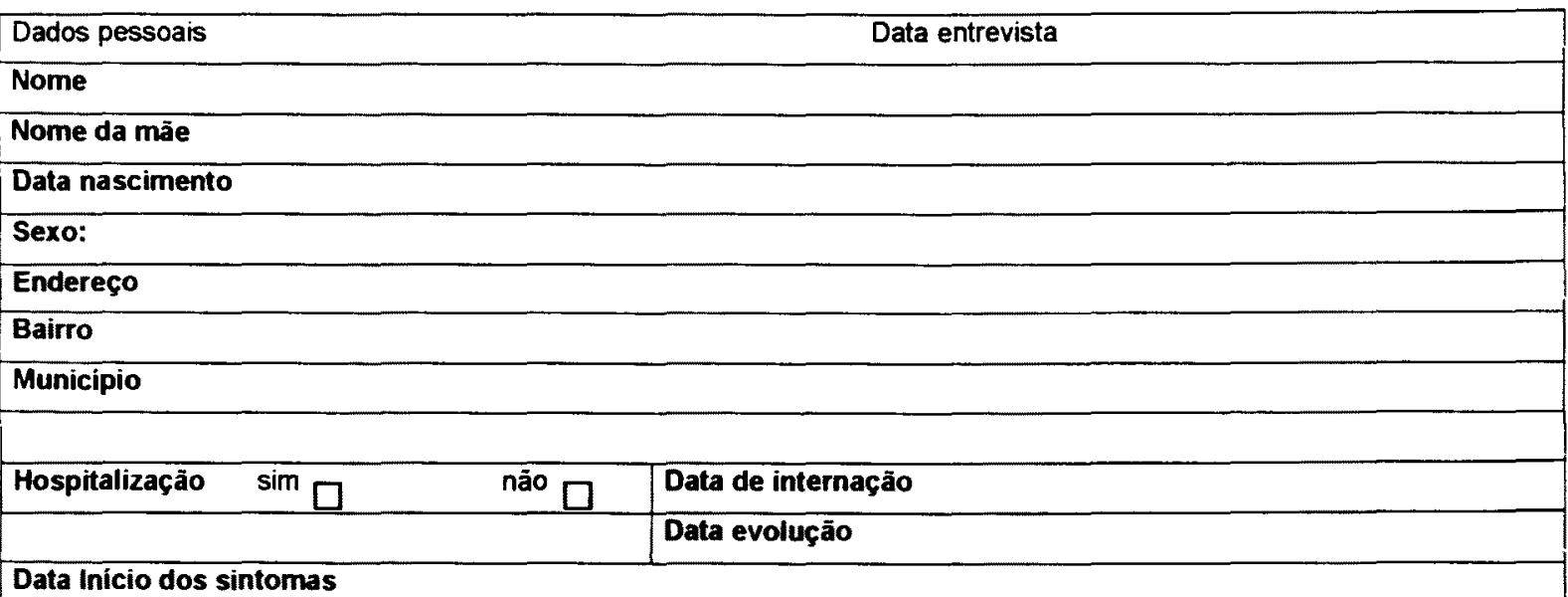

\section{Data Início dos sintomas}

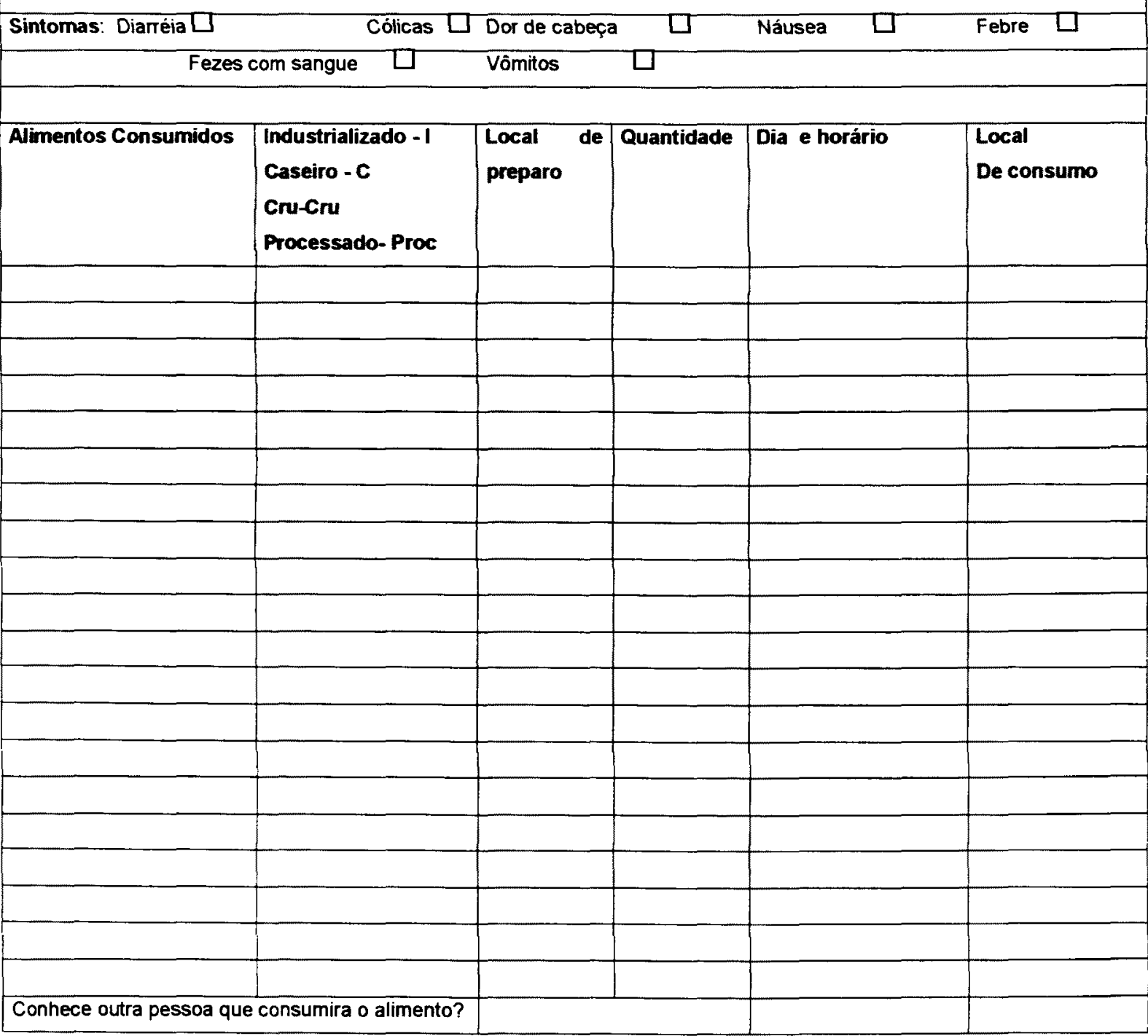




\section{Anexo 3}

Ficha de Investigação de Surto de DTA II - Resultados Laboratoriais (cont.)

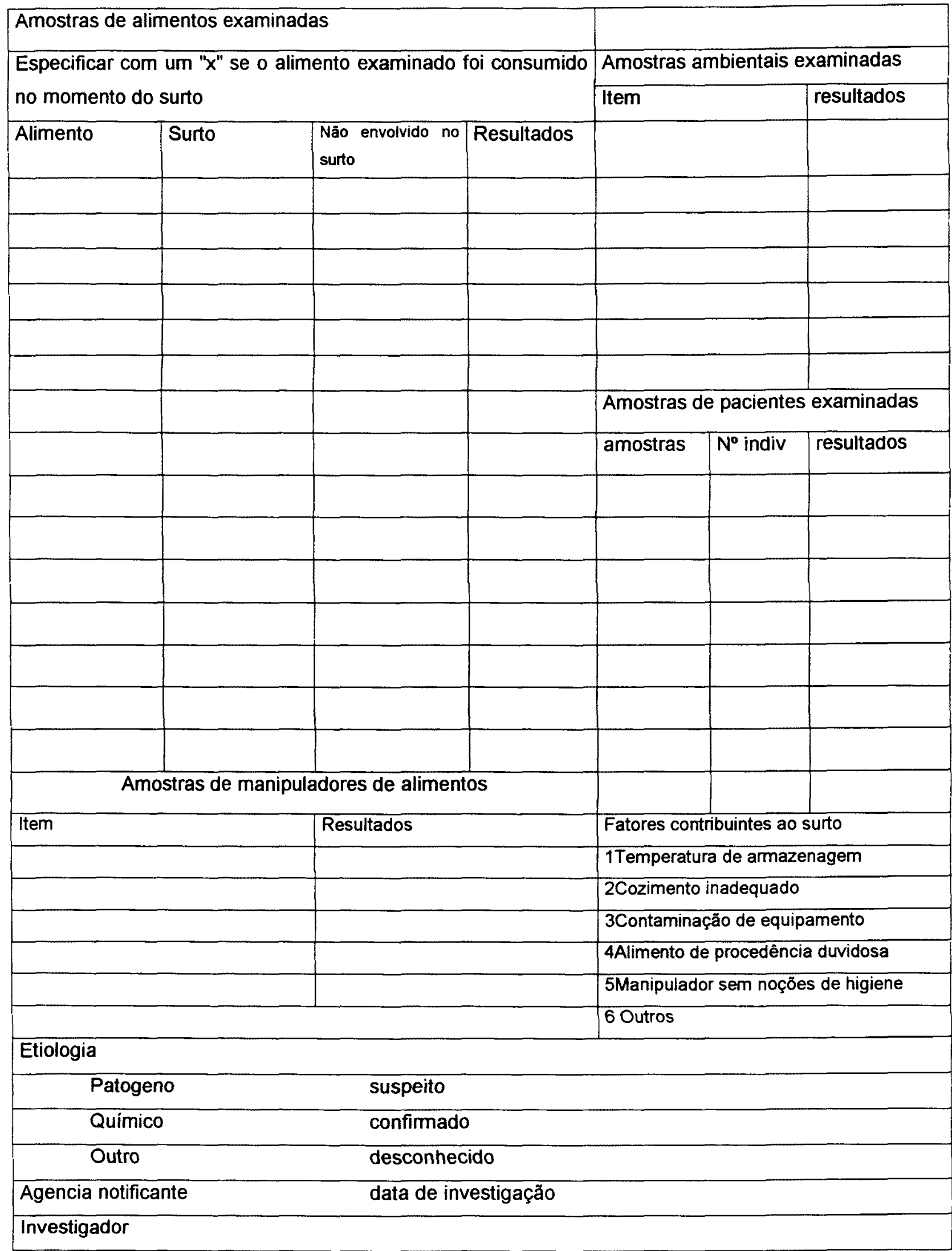

Fonte: Center for Disease Control and Prevention - CDC Form 52.13 adaptado 


\section{Anexo 4}

\section{Parâmetros microbiológicos e técnicas de identificação}

\begin{tabular}{|c|c|c|c|}
\hline $\begin{array}{l}\text { Parâmetros } \\
\text { microbiológicos }\end{array}$ & Meio & Condições de incubação & Procedimentos de identificação \\
\hline contagem total - lâmina & $\begin{array}{l}\text { contagem da lâmina - agar } \\
\text { (oxoid) }\end{array}$ & $32^{\circ} \mathrm{C}$ por $48 \mathrm{~h}$ & $\begin{array}{l}\text { enumeração de unidades } \\
\text { formadoras de células }\end{array}$ \\
\hline coliformes totais & agar Mac Conkey (oxoid) & $36^{\circ} \mathrm{C}$ por $48 \mathrm{~h}$ & $\begin{array}{l}\text { enumeração de unidades } \\
\text { formadoras de células } \\
\text { (fermentadoras de lactose }\end{array}$ \\
\hline E. coli & $\begin{array}{l}\text { agar roxo vermelho bílis + } \\
\text { MUG (oxoid) }\end{array}$ & $44^{\circ} \mathrm{C}$ por $24 \mathrm{~h}$ & $\begin{array}{l}\text { API } 20 E \text { testes bioquimicos } \\
\text { (Biomerieux) }\end{array}$ \\
\hline Staphylococcus aureus & $\begin{array}{l}\text { agar seletivo Baird parker } \\
\text { (oxoid) }\end{array}$ & $36^{\circ} \mathrm{C}$ por $48 \mathrm{~h}$ & $\begin{array}{l}\text { API } 20 \text { Staph. testes bioquimicos } \\
\text { (Biomerieux) }\end{array}$ \\
\hline \multirow[t]{3}{*}{ Salmonella } & $\begin{array}{l}\text { Pré enriquecimento em } \\
\text { buffered peptone water } \\
\text { (oxoid) }\end{array}$ & $\begin{array}{l}\text { Pré enriquecimento } 36^{\circ} \mathrm{C} \\
\text { por } 24 \mathrm{~h}\end{array}$ & $\begin{array}{l}\text { API } 20 \text { E testes bioquimicos) } \\
\text { identificação sorológica }\end{array}$ \\
\hline & $\begin{array}{l}\text { enriquecimento seletivo em } \\
\text { selenite cystine broth } \\
\text { (oxoid) }\end{array}$ & $\begin{array}{l}\text { enriquecimento seletivo } 42^{\circ} \\
\mathrm{C} \text { por } 24 \mathrm{~h}\end{array}$ & \\
\hline & $\begin{array}{l}\text { Isolamento em agar } \\
\text { Hektoen entérico (oxoid) }\end{array}$ & $\begin{array}{l}\text { Isolamento: } 36^{\circ} \mathrm{C} \text { por } 24 \mathrm{a} \\
48 \mathrm{~h}\end{array}$ & \\
\hline \multirow[t]{2}{*}{ Listeria sp. } & $\begin{array}{l}\text { enriquecimento seletivo em } \\
\text { Listeria enrichment broth } \\
\text { (oxoid) }\end{array}$ & $\begin{array}{l}\text { enriquecimento seletivo } 32^{\circ} \\
C \text { por } 24 \text { a } 48 \mathrm{~h}\end{array}$ & Haemolytic and catalase activity \\
\hline & $\begin{array}{l}\text { Isolamento em agar } \\
\text { Palkam (oxoid) }\end{array}$ & $\begin{array}{l}\text { isolamento: } 36^{\circ} \mathrm{C} \text { por } 24 \mathrm{a} \\
48 \mathrm{~h}\end{array}$ & $\begin{array}{l}\text { API testes bioquímicos Listeria } \\
\text { (Biomerieux) }\end{array}$ \\
\hline \multirow[t]{2}{*}{ Yersinia enterocolitica } & $\begin{array}{l}\text { enriquecimento seletivo em } \\
\text { peptone sorbitol bile salts } \\
\text { broth }\end{array}$ & $\begin{array}{l}\text { enriquecimento seletivo: } 4^{\circ} \\
C \text { por três semanas }\end{array}$ & $\begin{array}{l}\text { Lipase (Tween } 80 \text { ), esculin } \\
\text { hydrolysis, xylose fermentation, } \\
\text { pyrazinamide enzyme }\end{array}$ \\
\hline & $\begin{array}{l}\text { Isolamento em agar } \\
\text { seletivo Yersinia (oxoid) }\end{array}$ & isolamento: $32^{\circ} \mathrm{C}$ por $24 \mathrm{~h}$ & $\begin{array}{l}\text { API } 20 \text { E testes bioquímicos } \\
\text { (Biomerieux) identificaçăo } \\
\text { sorológica }\end{array}$ \\
\hline
\end{tabular}




\section{Anexo 5}

\section{Padrões de Referência Microbiológica para Alguns Alimentos Submetidos à}

Investigação Microbiológica

\begin{tabular}{|c|c|c|c|c|c|c|}
\hline \multirow[t]{2}{*}{ Alimentos } & \multirow[t]{2}{*}{ Testes bacteriológicos } & \multicolumn{4}{|c|}{ Padrōes } & \multirow[t]{2}{*}{ Fonte } \\
\hline & & n & $c$ & $m(c f u / g)$ & $M(c f u / g)$ & \\
\hline \multicolumn{6}{|c|}{ Cames cruas e preparaçōes a base de carne } & European regulations: Directive \\
\hline \multirow[t]{5}{*}{ minced meats } & Contagem total a $32^{\circ} \mathrm{C}$ & 5 & 2 & $5 \times 105$ & $5 \times 106$ & 94/65/CE du Conseil. 1994 \\
\hline & E. coli & 5 & 2 & $5 \times 10$ & $5 \times 102$ & \\
\hline & S. aureus & 5 & 2 & 102 & 103 & Italian regulations:DPR n. 309/1998: \\
\hline & Salmonella & 5 & 0 & aus. $10 \mathrm{~g}$ & aus. $10 \mathrm{~g}$ & OM 7.12 .1993 \\
\hline & L. monocytogenes & 3 & 2 & 11 & 110 & \\
\hline \multirow[t]{4}{*}{ preparações de carne } & E. coli & 5 & 2 & $5 \times 102$ & $5 \times 103$ & \\
\hline & S. aureus & 5 & 2 & $5 \times 102$ & $5 \times 103$ & \\
\hline & Salmonella & 5 & 0 & aus. $1 \mathrm{~g}$ & aus. $1 \mathrm{~g}$ & \\
\hline & L. monocytogenes & 3 & 2 & 11 & 110 & \\
\hline \multicolumn{7}{|c|}{ Alimentos cozidos prontos para o consumo } \\
\hline & Contagem total a $32^{\circ} \mathrm{C}$ & 5 & 2 & 105 & 106 & Emilia Romagna region. 1992 \\
\hline & Coliformes totais & 5 & 2 & 102 & 103 & Lombardia Region, 2001 \\
\hline & E. coli & 5 & 2 & 0 & 10 & Reneto Region, 1990 \\
\hline & S. aureus & 5 & 2 & 10 & 102 & Rondinini, 1997 \\
\hline & Salmonella & 5 & 0 & aus. $25 \mathrm{~g}$ & aus.25g & Mossel, 1995 \\
\hline & L. monocytogenes & 5 & 0 & aus. $25 g$ & aus.25g & ICMSF, 1986 \\
\hline \multicolumn{7}{|c|}{ Preparaçōes multi ingredientes (cozidas e cruas prontas para o consumo) } \\
\hline & Contagem total a $32^{\circ} \mathrm{C}$ & 5 & 2 & 106 & 107 & Emilia Romagna region. 1992 \\
\hline & E. coli & 5 & 2 & 0 & 10 & Lombardia Region, 2001 \\
\hline & S. aureus & 5 & 2 & 102 & 103 & Reneto Region, 1990 \\
\hline & Salmonella & 5 & 0 & aus. $25 g$ & aus. $25 \mathrm{~g}$ & Rondinini, 1997 \\
\hline & L. monocytogenes & 5 & 0 & aus. $25 g$ & aus. $25 g$ & Mossel, 1995 \\
\hline \multicolumn{7}{|l|}{ Quejjos cremosos } \\
\hline & Coliformes totais & 5 & 2 & 104 & 105 & European Regulation: Directive \\
\hline & E. coli & 5 & 2 & 102 & 103 & 92/46/CEE du Conseil, 1992 \\
\hline & S. aureus & 5 & 2 & 102 & 103 & Italian Regulation:DPR n. 54/ \\
\hline & Salmonella & 5 & 0 & aus. $25 \mathrm{~g}$ & aus. $25 \mathrm{~g}$ & 1997 \\
\hline & L. monocytogenes & 5 & 0 & aus. $25 \mathrm{~g}$ & aus. $25 \mathrm{~g}$ & \\
\hline \multicolumn{7}{|l|}{ Vegetais crus } \\
\hline & Contagem total a $32^{\circ} \mathrm{C}$ & 5 & 2 & $5 \times 105$ & & French Regulations: Arrêté \\
\hline & E. coli & 5 & 2 & 102 & & 22.03.1993; Arrêté 28.05.1997 \\
\hline & Salmonella & 5 & 0 & aus. $25 g$ & & ICMSF. 1986 \\
\hline & L. monocytogenes & 5 & 0 & aus. $25 g$ & & \\
\hline
\end{tabular}

$\mathrm{N}$ : number of sample units; $c$ : number of sample units with counts between $m$ and $M ; m$ conformity limit; $M$ acceptable limit Fonte: LEGNANI et. al 2004. 
Anexo 6. Aspectos Clínicos e Epidemiológicos Relacionados aos Principais Agentes Envolvidos nas DTA

\begin{tabular}{|c|c|c|c|c|c|c|}
\hline Etiolonis & $\begin{array}{l}\text { Periodo de } \\
\text { incubario }\end{array}$ & Sinais e Sintomas & $\begin{array}{l}\text { Duracioo da } \\
\text { doenca }\end{array}$ & $\begin{array}{l}\text { Alimentos } \\
\text { asseciados }\end{array}$ & $\begin{array}{l}\text { Testes } \\
\text { laborntoriais }\end{array}$ & Tratamento \\
\hline $\begin{array}{l}\text { Becterians } \\
\text { Bacillus anthracts }\end{array}$ & 2 dias à semanas & $\begin{array}{l}\text { Náusea vômutos. } \\
\text { mal estar, melena. } \\
\text { dor abdominal } \\
\text { aguda }\end{array}$ & Semanas & $\begin{array}{l}\text { Came contaminada } \\
\text { mal cozida }\end{array}$ & Sangue & $\begin{array}{l}\text { Penucilina e a } \\
\text { pnmeira opçăo para } \\
\text { anthrax } \\
\text { gastrnntestina! } \\
\text { adquirido } \\
\text { naturalmente } \\
\text { Ciprofloxacina e a } \\
\text { segunda opçăo }\end{array}$ \\
\hline $\begin{array}{l}\text { Hacillus cereus } \\
\text { strterotovina pre- } \\
\text { formada? }\end{array}$ & 1.6 horas & $\begin{array}{l}\text { Inicio repenumo de } \\
\text { nausea severa e } \\
\text { lomito Diartela } \\
\text { pode estar presente }\end{array}$ & 24 horas & $\begin{array}{l}\text { Aroz fnto ou } \\
\text { condo refngerado } \\
\text { impropnamente. } \\
\text { cames }\end{array}$ & $\begin{array}{l}\text { Normalmente o } \\
\text { diagnostico e } \\
\text { clinico. Os } \\
\text { laborationos clinicos } \\
\text { geraimente näo } \\
\text { identuficam este } \\
\text { organismo. Se } \\
\text { indicado. enviar } \\
\text { amostras de fezes e } \\
\text { alimentos a um } \\
\text { laboratónio de } \\
\text { referência para } \\
\text { cuiturze } \\
\text { identificação da } \\
\text { toxina }\end{array}$ & Cuidado de suponte \\
\hline $\begin{array}{l}\text { Bacilius cereus } \\
\text { (toxina diarteica) }\end{array}$ & 1016 horas & $\begin{array}{l}\text { Cabras } \\
\text { abdominass. } \\
\text { diarrea aquosa e } \\
\text { nausea }\end{array}$ & $24-48$ horas & $\begin{array}{l}\text { Cames ensopados. } \\
\text { molhos. creme de } \\
\text { baunilha }\end{array}$ & $\begin{array}{l}\text { Teste não } \\
\text { necessano. auto. } \\
\text { limtante } \\
\text { (considerar o teste } \\
\text { de alimentos e tezes } \\
\text { para toxuna em } \\
\text { surtos) }\end{array}$ & Cudado de suporte \\
\hline $\begin{array}{l}\text { Erucella abortus } B . \\
\text { melitensis e } B . \text { sus }\end{array}$ & $7-21$ dias & 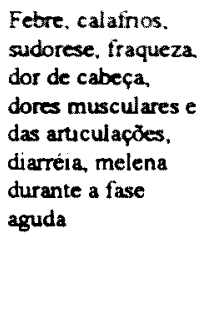 & Semanas & $\begin{array}{l}\text { Leite cru, quejo de } \\
\text { cabra fetto de lette } \\
\text { näo pasteunzado. } \\
\text { cames } \\
\text { contaminadas }\end{array}$ & $\begin{array}{l}\text { Cultura de sangue e } \\
\text { sorologia positiva }\end{array}$ & $\begin{array}{l}\text { Agudo: rfampina } \\
\text { doxaciclina diana } \\
\text { por mais ou menos } \\
6 \text { semanas. } \\
\text { Infecçöes com } \\
\text { complicaçðes } \\
\text { requerem terapia } \\
\text { combinada com } \\
\text { nifampina } \\
\text { tetraciclina e um } \\
\text { aminoglicosideo }\end{array}$ \\
\hline $\begin{array}{l}\text { Campwlobacter } \\
\text { jejunt }\end{array}$ & $2-5$ dias & $\begin{array}{l}\text { Diarreia căibras } \\
\text { febre e vómitos. } \\
\text { diarréa pode ser } \\
\text { sangurnolenta }\end{array}$ & $2-10$ dias & $\begin{array}{l}\text { Carne de ave crua e } \\
\text { mal cozda lete } \\
\text { nao pasteunzada. } \\
\text { agua contaminada }\end{array}$ & $\begin{array}{l}\text { Cultura de fezes de } \\
\text { rotina. } \\
\text { Campylobacter } \\
\text { requer meto } \\
\text { especial e } \\
\text { incubaça a } 42^{\circ} \mathrm{C} \\
\text { para crescer }\end{array}$ & $\begin{array}{l}\text { Cuidado supone. } \\
\text { Para os casos } \\
\text { severos, } \\
\text { antibióticos como a } \\
\text { eritromicina e } \\
\text { quinolones podem } \\
\text { ser indicador } \\
\text { inicialmente na } \\
\text { doença diarréca A } \\
\text { Síndrome de } \\
\text { Guillain-Barré pode } \\
\text { ser uma sequela. }\end{array}$ \\
\hline $\begin{array}{l}\text { Closindium } \\
\text { botulinum-ctiancas } \\
\text { c adultos floxina } \\
\text { pre-formada) }\end{array}$ & $12-72$ horas & $\begin{array}{l}\text { Vômitos. diarréia } \\
\text { visāo manchada. } \\
\text { diplopia disfagia e } \\
\text { fraqueza muscular } \\
\text { descendente }\end{array}$ & $\begin{array}{l}\text { Variavel (de dias à } \\
\text { meses). Pode } \\
\text { evolur a falencia } \\
\text { respiratoria e óbito }\end{array}$ & $\begin{array}{l}\text { Alimentos } \\
\text { enlatados } \\
\text { domesticamente de } \\
\text { baixa acidez } \\
\text { alimentos } \\
\text { comercialmente } \\
\text { enlatados de } \\
\text { maneira impropna } \\
\text { pexes fermentados } \\
\text { z domesticamente } \\
\text { enlatados. oleos } \\
\text { curtidos com ervas. } \\
\text { batatas assudas em } \\
\text { papel aluminio. } \\
\text { creme de quejos. } \\
\text { alho engarratado. } \\
\text { alimentos mantidos } \\
\text { aquecidos por } \\
\text { longos periodos de } \\
\text { tempo (ex em } \\
\text { fomos) }\end{array}$ & $\begin{array}{l}\text { Fezes, soro e } \\
\text { alimentos podem } \\
\text { ser testados para a } \\
\text { toxina Com Fezes e } \\
\text { alimentos tamberm } \\
\text { pode-se realizar } \\
\text { cultura para o } \\
\text { organismo. }\end{array}$ & $\begin{array}{l}\text { Cuidado de suporte. } \\
\text { A antitoxina } \\
\text { botulinica e utul se } \\
\text { ministrada no inicro } \\
\text { do curso da doença }\end{array}$ \\
\hline
\end{tabular}


Anexo 6. Aspectos clínicos e epidemiológicos relacionados aos principais agentes envolvidos nas DTA (cont.)

\begin{tabular}{|c|c|c|c|c|c|c|}
\hline Etiologia & $\begin{array}{l}\text { Periodo de } \\
\text { incubario }\end{array}$ & Sinais e Sintomas & $\begin{array}{l}\text { Duraciio da } \\
\text { doença }\end{array}$ & $\begin{array}{l}\text { Alimentos } \\
\text { associados }\end{array}$ & $\begin{array}{l}\text { Testes } \\
\text { laboratoriais }\end{array}$ & Tratamento \\
\hline $\begin{array}{l}\text { Docteriana (conc) } \\
\text { Clostridium } \\
\text { botulinum - em } \\
\text { individuos menores } \\
\text { de } 12 \text { meses }\end{array}$ & $12-72$ hores & $\begin{array}{l}\text { Letargia fraqueza. } \\
\text { falta de apetite, } \\
\text { constupação. } \\
\text { hipotonia controle } \\
\text { deficiente da } \\
\text { cabeça. retlexos de } \\
\text { amordaçat e } \\
\text { succionar (mamar) } \\
\text { prejudicados }\end{array}$ & Variável & $\begin{array}{l}\text { Mel, vegetais e } \\
\text { frutas envasados em } \\
\text { casa xarope } \\
\text { (melado) de mulho }\end{array}$ & $\begin{array}{l}\text { Fezes soro e } \\
\text { alimento podem ser } \\
\text { testados para a } \\
\text { toxina. Cultura de } \\
\text { fezes e alimentos } \\
\text { pode ser realizada } \\
\text { para o } \\
\text { microorganismo }\end{array}$ & $\begin{array}{l}\text { Cuidado de suporte } \\
\text { e Imunoglobulina } \\
\text { bolutínioa. A } \\
\text { antitoxina } \\
\text { botulínica } \\
\text { geralmente não é } \\
\text { recomendada para } \\
\text { individuos desta } \\
\text { faixa etana }\end{array}$ \\
\hline $\begin{array}{l}\text { Clostndium } \\
\text { perinngens - toxna }\end{array}$ & $8-16$ horas & $\begin{array}{l}\text { Diameia aquosa } \\
\text { nausea. cabras } \\
\text { abdominats. tebre } \\
\text { rara. }\end{array}$ & $24-48$ horas & $\begin{array}{l}\text { Came, came de } \\
\text { aves, molhos } \\
\text { (carne), alimentos } \\
\text { desidratados ou pre- } \\
\text { cozidos, alimentos } \\
\text { em condiçöes } \\
\text { impróprias de } \\
\text { tempo e } \\
\text { temperatura }\end{array}$ & $\begin{array}{l}\text { Fezes podem ser } \\
\text { testadas para a } \\
\text { enterotoxina e } \\
\text { pode-se realtzar } \\
\text { culbura para o } \\
\text { organismo. Uma } \\
\text { vez que o } \\
\text { Clostridium } \\
\text { perfngens pode } \\
\text { normaimente ser } \\
\text { encontrado nas } \\
\text { fezes. deve-se } \\
\text { realizar culturas } \\
\text { quantitativas }\end{array}$ & $\begin{array}{l}\text { Cuidado de supone } \\
\text { Antibióticos nào } \\
\text { são indicados }\end{array}$ \\
\hline $\begin{array}{l}\text { Ecoli (EHEC) } \\
\text { Enterohemorragica } \\
\text { inclundo E. coll } \\
\text { 157 H7 e outras } \\
\text { produtoras de } \\
\text { toxuna Shiga } \\
\text { Ecol! (STEC) }\end{array}$ & 1.8 dias & $\begin{array}{l}\text { Diarreia severa } \\
\text { geraimente } \\
\text { sangumolenta dor } \\
\text { abdomunal e } \\
\text { vömios. Febre } \\
\text { geraimente } \\
\text { inexpressiva ou } \\
\text { ausente. Mals } \\
\text { comum em criancas } \\
\text { abaixo de } 4 \text { anos. }\end{array}$ & $5-10$ dias & $\begin{array}{l}\text { Came de vaca mal } \\
\text { cozida } \\
\text { (hamburguet). levte } \\
\text { não pasteunzado e } \\
\text { sucos, frutas e } \\
\text { vegetais crus } \\
\text { (brotos), raramente } \\
\text { em embutidos } \\
\text { (salame) e agua } \\
\text { contamunada }\end{array}$ & 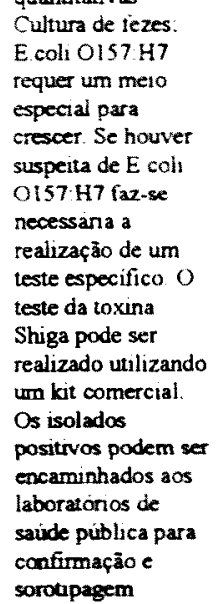 & $\begin{array}{l}\text { Cuidado de supone. } \\
\text { monitoramento das } \\
\text { funçós renars. } \\
\text { hemoglobina e } \\
\text { aglutinação } \\
\text { plaquetana. A } \\
\text { infecçao por E colı } \\
\text { Ol57:H7 esta } \\
\text { também associada } \\
\text { com a sindrome } \\
\text { hemolitica urêmica } \\
\text { (SHU), que pode } \\
\text { causar } \\
\text { complicações } \\
\text { crönicas. Estudos } \\
\text { indicam que } \\
\text { antibióticos podem } \\
\text { promover o } \\
\text { desenvolvimento da } \\
\text { SHU. }\end{array}$ \\
\hline $\begin{array}{l}\text { Ecoli } \\
\text { Enterotoxigènuca } \\
\text { (ETEC) }\end{array}$ & 1.3 dias & $\begin{array}{l}\text { Dharréia aquosa. } \\
\text { cãibras abdominars, } \\
\text { podendo apresentar } \\
\text { vómitos }\end{array}$ & De 3 a 7 dias & $\begin{array}{l}\text { Agua ou alimento } \\
\text { contaminado com } \\
\text { fezes humanas }\end{array}$ & $\begin{array}{l}\text { Cultura de fezes. } \\
\text { ETEC requer } \\
\text { técnicas } \\
\text { laboratonais } \\
\text { especiais para } \\
\text { identificação. Caso } \\
\text { haja suspeita. é } \\
\text { preciso solicitar } \\
\text { testes especificos }\end{array}$ & $\begin{array}{l}\text { Cuidado de suporte } \\
\text { O uso de } \\
\text { antibióticos } \\
\text { raramente é } \\
\text { necessário exceto } \\
\text { em casos raros. } \\
\text { Dentre os } \\
\text { recomendados estão } \\
\text { o TMP-SMX e } \\
\text { quinolones }\end{array}$ \\
\hline \multirow[t]{2}{*}{$\begin{array}{l}\text { Listeria } \\
\text { monocvtogenes }\end{array}$} & $\begin{array}{l}9.48 \text { horas para os } \\
\text { sintomas } \\
\text { gastrointestunats. } \\
6 \text { semanas para a } \\
\text { doenca invasiva }\end{array}$ & $\begin{array}{l}\text { Febres, dores } \\
\text { musculares e } \\
\text { nausea ou diarreia } \\
\text { Mulheres gravidas } \\
\text { podern apresentar } \\
\text { um quadro } \\
\text { semelhante a uma } \\
\text { gnipe moderada e a } \\
\text { infecfäo pode } \\
\text { ocastonar parto } \\
\text { prematuro ou } \\
\text { natumores } \\
\text { Pacientes idosos ou } \\
\text { Imunocomprometid } \\
\text { os podem } \\
\text { apresentar } \\
\text { bacteremia ou } \\
\text { meningite }\end{array}$ & Vanável & $\begin{array}{l}\text { Queijos frescos } \\
\text { cremosos, lette } \\
\text { inadequadamente } \\
\text { ou não } \\
\text { pasteurizado, } \\
\text { alimentos de pronto } \\
\text { consumo (deìvery) } \\
\text { cachomos quentes. }\end{array}$ & $\begin{array}{l}\text { Cultura de sangue } \\
\text { ou fluido } \\
\text { cerebroespininal Hả } \\
\text { portadores } \\
\text { assintomaticos con } \\
\text { eliminação do } \\
\text { agente peias tezes. } \\
\text { porem sua cuitura } \\
\text { näo e ưul o } \\
\text { Anticorpo para a } \\
\text { listerolisina pode } \\
\text { ser ítil para } \\
\text { identificar um surto } \\
\text { tetrospectivamente. }\end{array}$ & $\begin{array}{l}\text { Cuidado de suporte } \\
\text { e antibióticos, } \\
\text { ampicilina } \\
\text { intravenosa. } \\
\text { penicilina ou TMP. } \\
\text { SMX são } \\
\text { recomendados para } \\
\text { a doença invasiva }\end{array}$ \\
\hline & $\begin{array}{l}\text { De } 0 \text { a } 12 \text { meses de } \\
\text { dade }\end{array}$ & $\begin{array}{l}\text { Infectados atraves } \\
\text { da màe sob nsco } \\
\text { para sepse ou } \\
\text { meningite }\end{array}$ & & & & \\
\hline
\end{tabular}




\section{Anexo 6. Aspectos Clínicos e Epidemiológicos Relacionados aos Principais}

\section{Agentes Envolvidos nas DTA (cont.)}

\begin{tabular}{|c|c|c|c|c|c|c|}
\hline Etiologia & $\begin{array}{l}\text { Periodo de } \\
\text { incubacio }\end{array}$ & Sinuis e Sintomas & $\begin{array}{l}\text { Duraçüo da } \\
\text { doenca }\end{array}$ & $\begin{array}{l}\text { Alimentos } \\
\text { associados }\end{array}$ & $\begin{array}{l}\text { Testes } \\
\text { laboratoriais }\end{array}$ & Tratsmento \\
\hline \multicolumn{7}{|l|}{ Bacteriana (cont.) } \\
\hline Salmonella spp. & 1.3 dias & 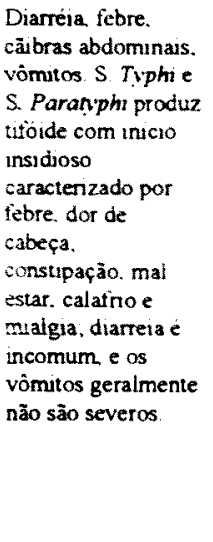 & +7 dias & $\begin{array}{l}\text { Ovos } \\
\text { contaminados. } \\
\text { came de aves. leite } \\
\text { ou suco não } \\
\text { pasteunzado, } \\
\text { queijos, frutas e } \\
\text { vegetais crus } \\
\text { (alfafa brotos, } \\
\text { melöes). As } \\
\text { epidemias } \\
\text { ocasionadas por } S \text {. } \\
\text { Typh são } \\
\text { geralmente } \\
\text { relacionadas à } \\
\text { contaminação fecal } \\
\text { da água ou de } \\
\text { alimentos } \\
\text { provenientes do } \\
\text { comercio informal }\end{array}$ & $\begin{array}{l}\text { Cultura de fezes de } \\
\text { rotina }\end{array}$ & 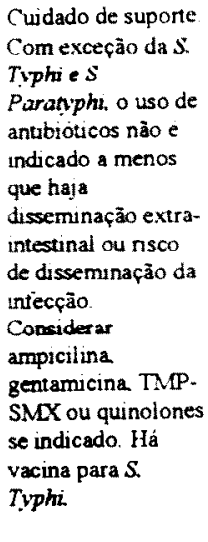 \\
\hline Shigella spp. & $24-48$ horas & $\begin{array}{l}\text { dores abdominals. } \\
\text { tebre e diarreta. As } \\
\text { lezes podem conter } \\
\text { sangue e muco }\end{array}$ & +7 dias & $\begin{array}{l}\text { alimento ou agua } \\
\text { contaminada com } \\
\text { fezes humanas. } \\
\text { Normaimente com } \\
\text { disseminação } \\
\text { pessoa-pessoa c } \\
\text { transmissão oral- } \\
\text { fecal. Manipulaça } \\
\text { de alimentos de } \\
\text { pronto consumo por } \\
\text { infectados, } \\
\text { incluindo vegetals } \\
\text { crus, saladas e } \\
\text { sanduiches. }\end{array}$ & $\begin{array}{l}\text { Cultura de lezzes de } \\
\text { rotina }\end{array}$ & $\begin{array}{l}\text { cuidado de suporte } \\
\text { Uso de TM.SMX } \\
\text { se o organismo tor } \\
\text { susceptivel. acido } \\
\text { nalidixico ou outros } \\
\text { quinones podem ser } \\
\text { indicados se o } \\
\text { organismo tor } \\
\text { resistente. } \\
\text { especialmente em } \\
\text { paises em } \\
\text { desenvolvimento. }\end{array}$ \\
\hline $\begin{array}{l}\text { Staphylococcus } \\
\text { aureus } \\
\text { (enterotoxina } \\
\text { preformada) }\end{array}$ & $1-6$ horas & $\begin{array}{l}\text { início repentino de } \\
\text { náusea severa e } \\
\text { vômitos. Cäibras } \\
\text { abdominais. } \\
\text { Diarreia e febre } \\
\text { podem estar } \\
\text { presentes }\end{array}$ & $24-48$ horas & $\begin{array}{l}\text { alimentos não } \\
\text { refrigerados ou } \\
\text { impropriamente } \\
\text { refrigerados, } \\
\text { saladas contendo } \\
\text { balata e ovos. } \\
\text { massas e folhados } \\
\text { com recheios } \\
\text { cremosos }\end{array}$ & $\begin{array}{l}\text { Normalmente } \\
\text { diagnóstico clinico } \\
\text { Fezes, vómitos e } \\
\text { alimentos podem } \\
\text { ser testados para a } \\
\text { toxina, podendo } \\
\text { realizar cultura se } \\
\text { indicado }\end{array}$ & Cuidado de suporte \\
\hline $\begin{array}{l}\text { Vibrio cholerae } \\
\text { toxina) }\end{array}$ & 2472 horas & $\begin{array}{l}\text { diarrcia aquosa } \\
\text { protusa e vömitos. } \\
\text { podendo levar à } \\
\text { desidrataçäo severa } \\
\text { e óbito em horas }\end{array}$ & 3-7 dias & $\begin{array}{l}\text { agua contaminada, } \\
\text { peixe, moluscos, } \\
\text { alimentos vendidos } \\
\text { em ambulantes. }\end{array}$ & $\begin{array}{l}\text { Cultura de fezes: } \\
\text { Vibrio cholerae } \\
\text { requer meio } \\
\text { especial para } \\
\text { crescer. Caso haja } \\
\text { suspeita do agente, } \\
\text { um teste especifico } \\
\text { deve ser realizado }\end{array}$ & $\begin{array}{l}\text { cuidado de suporte } \\
\text { com rehidrataçăo } \\
\text { intensa (oral e } \\
\text { intravenosa). Em } \\
\text { casos confirmados } \\
\text { de colera. } \\
\text { tetraciclina ou } \\
\text { doxiciclina são } \\
\text { recomendadas para } \\
\text { adultos, e TMP. } \\
\text { SMX para crianças } \\
\text { (<8 anos). }\end{array}$ \\
\hline $\begin{array}{l}\text { Vibro para- } \\
\text { haemolvticus }\end{array}$ & $2-48$ horas & $\begin{array}{l}\text { Diarréia aquosa. } \\
\text { cãibras abdominats. } \\
\text { náusea e vömitos }\end{array}$ & 2.5 dias & $\begin{array}{l}\text { Frutos do mar crus } \\
\text { ou mal cozidos, } \\
\text { como peixes e } \\
\text { manscos }\end{array}$ & $\begin{array}{l}\text { Cultura de fezes. } \\
\text { Vibrio } \\
\text { parahaemoliticos } \\
\text { requer um meio } \\
\text { especial para } \\
\text { crescer. Caso haja } \\
\text { suspeita do agente. } \\
\text { um teste especifico } \\
\text { é necessario }\end{array}$ & $\begin{array}{l}\text { Cudado de suponte } \\
\text { O uso de } \\
\text { antibióticos e } \\
\text { recomendado em } \\
\text { casos severos } \\
\text { tetracicina. } \\
\text { doxiciclina. } \\
\text { gentamicina e } \\
\text { cefotaxime }\end{array}$ \\
\hline
\end{tabular}


Anexo 6. Aspectos Clínicos e Epidemiológicos Relacionados aos Principais Agentes Envolvidos nas DTA (cont.)

\begin{tabular}{|c|c|c|c|c|c|c|}
\hline Etiologia & $\begin{array}{l}\text { Periodo de } \\
\text { incubacão }\end{array}$ & Sinais e Sintomas & $\begin{array}{l}\text { Duração da } \\
\text { doença }\end{array}$ & $\begin{array}{l}\text { Alimentos } \\
\text { associados }\end{array}$ & $\begin{array}{l}\text { Testes } \\
\text { laboratoriais }\end{array}$ & Tratamento \\
\hline $\begin{array}{l}\text { Bacteriana (cont) } \\
\text { Vibrio Vulnificus }\end{array}$ & 1-7dias & $\begin{array}{l}\text { Diarreia aquosa dor } \\
\text { abdominal, } \\
\text { bacteremia e lesões. } \\
\text { Comum em } \\
\text { imunocomprometid } \\
\text { os ou pacientes com } \\
\text { doenças hepaticas } \\
\text { crônicas } \\
\text { (apresentando } \\
\text { lesões cutâneas } \\
\text { bullous). Pode ser } \\
\text { fatal em pacientes } \\
\text { com doença } \\
\text { hepática e } \\
\text { imunocomprometid } \\
\text { os }\end{array}$ & $2-8$ dias & $\begin{array}{l}\text { mariscos cruz ou } \\
\text { mal cozidos, } \\
\text { especialmente } \\
\text { ostras, outros } \\
\text { alimentos de } \\
\text { origem marinha } \\
\text { contaminados, e } \\
\text { feridas abertas } \\
\text { expostas à água do } \\
\text { mar }\end{array}$ & $\begin{array}{l}\text { Cultura de fezes, } \\
\text { feridas ou sangue. } \\
\text { Vibio vulnificus } \\
\text { requer um meio } \\
\text { especial para } \\
\text { crescer. Caso haja } \\
\text { suspeita do agente. } \\
\text { faz-se necessária a } \\
\text { utilização de um } \\
\text { teste especifico. }\end{array}$ & $\begin{array}{l}\text { Cuidado de supone } \\
\text { e antibióticos: } \\
\text { tetraciclina. } \\
\text { doxiciclina e } \\
\text { ceftazidime são } \\
\text { algumas } \\
\text { recomendaçōes }\end{array}$ \\
\hline $\begin{array}{l}\text { Yersinia } \\
\text { enterocolitica e } \\
\text { Y pseudotuberculos } \\
\text { is }\end{array}$ & $24-48$ horas & $\begin{array}{l}\text { Sintomas } \\
\text { semelhantes a } \\
\text { apendicite (diarréia, } \\
\text { vômitos, febre e } \\
\text { dores abdominais) } \\
\text { comum em crianças } \\
\text { mais velhas e } \\
\text { adultos jovens } \\
\text { Pode ocorrer } \\
\text { erup̧ão cutânea } \\
\text { escarliniforme com } \\
\text { Y. } \\
\text { pseudotuberculosis }\end{array}$ & $\begin{array}{l}\text { 1-3 semanas, } \\
\text { geralmente auto- } \\
\text { limitante }\end{array}$ & $\begin{array}{l}\text { Carne suina mal } \\
\text { cozida, leite não } \\
\text { pasteurizado, tofu, } \\
\text { água contaminada. } \\
\text { Infeç̧öes tem } \\
\text { ocorndo em } \\
\text { crianças cujas babás } \\
\text { manipularam } \\
\text { chitterlings }\end{array}$ & $\begin{array}{l}\text { Cultura de fezes, } \\
\text { vômitos ou sangue. } \\
\text { Yersinia requer um } \\
\text { meio especial para } \\
\text { crescer. Caso haja a } \\
\text { suspeita do agente. } \\
\text { um teste especifico } \\
\text { é necessário. } \\
\text { Sorologia está } \\
\text { disponivel em } \\
\text { laboratónios de } \\
\text { pesquisa e de } \\
\text { referência. }\end{array}$ & $\begin{array}{l}\text { Cuidado de suporte. } \\
\text { Caso ocorra } \\
\text { septicemia ou } \\
\text { outras doenças } \\
\text { invasivas. } \\
\text { recomenda-se o uso } \\
\text { de terapia com } \\
\text { gentamicina ou } \\
\text { cefotaxime } \\
\text { (doxiciclina e } \\
\text { ciprofloxacina } \\
\text { tambem podem ser } \\
\text { utilizadas) }\end{array}$ \\
\hline \multicolumn{7}{|l|}{ Viral } \\
\hline Hepatite A & $\begin{array}{l}\text { Média de } 28 \text { dias } \\
\text { (15-50 dias) }\end{array}$ & $\begin{array}{l}\text { Diarréia, urina } \\
\text { turva, ictericia, e } \\
\text { sintomas similares a } \\
\text { gripe: febre, dor de } \\
\text { cabeça, náusea e } \\
\text { dor abdominal }\end{array}$ & $\begin{array}{l}\text { Variável } \\
2 \text { semanas a } 3 \\
\text { meses }\end{array}$ & $\begin{array}{l}\text { Mariscos } \\
\text { provenientes de } \\
\text { águas } \\
\text { contaminadas, } \\
\text { produtos agricolas } \\
\text { crus, água destinada } \\
\text { ao consumo } \\
\text { contaminada, } \\
\text { alimentos mal } \\
\text { cozidos e alimentos } \\
\text { cozidos que năo } \\
\text { foram reaquecidos } \\
\text { após contato com } \\
\text { manipulador } \\
\text { contaminado. }\end{array}$ & $\begin{array}{l}\text { Aumento em ALT. } \\
\text { bilirubina, IgM } \\
\text { positivo e } \\
\text { anticorpos anti } \\
\text { hepatite A }\end{array}$ & $\begin{array}{l}\text { Cuidado de suporte. } \\
\text { Prevenção atraves } \\
\text { de imunização }\end{array}$ \\
\hline $\begin{array}{l}\text { Voroviroses (e } \\
\text { outros caliciviroses) }\end{array}$ & $12-48$ horas & $\begin{array}{l}\text { Náuseas, vômitos, } \\
\text { cãibras abdominais, } \\
\text { diarréia, febre, } \\
\text { miaigia e menos } \\
\text { freqüentemente, dor } \\
\text { de cabeça. Diarréia } \\
\text { é mais prevalente } \\
\text { em adultos e } \\
\text { vômitos são mais } \\
\text { prevalentes em } \\
\text { crianças }\end{array}$ & $12-60$ horas & $\begin{array}{l}\text { Moluscos, } \\
\text { alimentos } \\
\text { contaminados com } \\
\text { fezes, alimentos de } \\
\text { pronto consumo } \\
\text { manipulados por } \\
\text { individuos } \\
\text { infectados (saladas, } \\
\text { sanduíches, sorvete, } \\
\text { biscoitos e frutas) }\end{array}$ & $\begin{array}{l}\text { RT-PCR de rotina e } \\
\text { EM em fezes } \\
\text { frescas näo } \\
\text { submetidas à } \\
\text { conservação. } \\
\text { Diagnóstico clínico. } \\
\text { culturas de } \\
\text { bactérias negativas: } \\
\text { fezes negativadas } \\
\text { por WBCs }\end{array}$ & $\begin{array}{l}\text { Cuidado de suporte } \\
\text { como reidratação. } \\
\text { Boas praticas de } \\
\text { higiene }\end{array}$ \\
\hline Rotavirus & 1-3 dias & $\begin{array}{l}\text { Vômitos diarréia } \\
\text { aquosa, febre } \\
\text { discreta, } \\
\text { intolerância } \\
\text { temporária à lactose } \\
\text { pode ocorrer. } \\
\text { Grupos vulneráveis: } \\
\text { crianças e idosos e } \\
\text { imunocomprometid } \\
\text { os }\end{array}$ & 48 dias & $\begin{array}{l}\text { Alimentos } \\
\text { contaminados com } \\
\text { fezes. Alimentos de } \\
\text { consumo imediato } \\
\text { manipulados por } \\
\text { indivíduos } \\
\text { infectados (saladas } \\
\text { e frutas) }\end{array}$ & $\begin{array}{l}\text { Identificação do } \\
\text { vírus na fezes } \\
\text { através de ensaios } \\
\text { imunoquimicos }\end{array}$ & $\begin{array}{l}\text { Cuidado de suporte } \\
\text { Diarréia Severa } \\
\text { pode requerer } \\
\text { reposição de tluidos } \\
\text { e de eletrólitos }\end{array}$ \\
\hline $\begin{array}{l}\text { Outros agentes } \\
\text { virais (astroviroses. } \\
\text { adenoviroses. } \\
\text { parvoviroses) }\end{array}$ & $10-70$ horas & $\begin{array}{l}\text { Náusea vômitos. } \\
\text { diarréia, mal estar, } \\
\text { dor abdominal, dor } \\
\text { de cabeça e febre }\end{array}$ & 2-9 dias & $\begin{array}{l}\text { Alimentos } \\
\text { contaminados com } \\
\text { fezes. Alimentos } \\
\text { prontos para o } \\
\text { consumo } \\
\text { manipulados por } \\
\text { individuos } \\
\text { infectados. } \\
\text { Mariscos }\end{array}$ & $\begin{array}{l}\text { Identificação do } \\
\text { virus nas primeiras } \\
\text { amostras de } \\
\text { fezes. Sorologia. } \\
\text { Kits comerciais de } \\
\text { ELISA disponiveis } \\
\text { para adenoviroses e } \\
\text { astroviroses }\end{array}$ & $\begin{array}{l}\text { Cuidado de suporte. } \\
\text { geralmente brando. } \\
\text { auto-limitante. Boas } \\
\text { práticas de higiene }\end{array}$ \\
\hline
\end{tabular}


Anexo 6. Aspectos Clinicos e Epidemiológicos Relacionados aos Principais Agentes Envolvidos nas DTA (cont.)

\begin{tabular}{|c|c|c|c|c|c|c|}
\hline Etiologit: & $\begin{array}{l}\text { Periodo de } \\
\text { incubactio }\end{array}$ & Sinuis e Sintomas & $\begin{array}{l}\text { Duracio ds } \\
\text { doenca }\end{array}$ & $\begin{array}{l}\text { Alimentos } \\
\text { asseciados }\end{array}$ & $\begin{array}{l}\text { Testes } \\
\text { laboratoriais }\end{array}$ & Tratamento \\
\hline \multicolumn{7}{|l|}{ Parasitas } \\
\hline $\begin{array}{l}\text { Angiostrongilus } \\
\text { Cantonensis }\end{array}$ & $\begin{array}{l}1 \text { semana a um més } \\
\text { ou mais }\end{array}$ & $\begin{array}{l}\text { Dor de cabeça } \\
\text { severa, nausea. } \\
\text { vômitos. rigdez no } \\
\text { pescoço. } \\
\text { parestesıas. } \\
\text { hiperestesıas. } \\
\text { apreensão } \\
\text { fataquesi. e outras } \\
\text { anormalidades } \\
\text { nourologates }\end{array}$ & de semanas a meses & $\begin{array}{l}\text { hospedeiros } \\
\text { intermediarios crus } \\
\text { ou mal cozdos } \\
\text { (lesmas. manscos. } \\
\text { scargot) } \\
\text { hospedeiros } \\
\text { infectados } \\
\text { paraténicos } \\
\text { (veiculadores) (ex } \\
\text { carangueyos. } \\
\text { camaräo de agua } \\
\text { fresca) } \\
\text { hortagranjeiros } \\
\text { frescos } \\
\text { contamnados com } \\
\text { hospedeiros } \\
\text { intermediarios ou } \\
\text { veiculadores }\end{array}$ & $\begin{array}{l}\text { Exame de CSF para } \\
\text { hipertensäo. } \\
\text { proteina, leucócitos } \\
\text { e eosinófilos. Teste } \\
\text { sorológico } \\
\text { utilizando ELISA } \\
\text { para detectar } \\
\text { antioorpos } \\
\text { especificos pata o } \\
\text { agente }\end{array}$ & $\begin{array}{l}\text { Cudado de supore. } \\
\text { Repeat lumbar } \\
\text { punctures s lerapia } \\
\text { com } \\
\text { corticossteroides } \\
\text { pode ser utilizada } \\
\text { para pacientes com } \\
\text { quadros mass } \\
\text { severos }\end{array}$ \\
\hline Crypt oupondium & $2-10$ dias & $\begin{array}{l}\text { Diarreia } \\
\text { (geralmente } \\
\text { aquosa). cãibras } \\
\text { estomacass. } \\
\text { indisposição } \\
\text { estomacal. lebre } \\
\text { discreta }\end{array}$ & $\begin{array}{l}\text { Pode diminuir e } \\
\text { reincidir por } \\
\text { semanas e ate } \\
\text { meses }\end{array}$ & $\begin{array}{l}\text { qualquer alimento } \\
\text { mal cozido ou } \\
\text { contaminado por } \\
\text { um manpulador } \\
\text { com o parasita apos } \\
\text { cozmento. agua } \\
\text { destinada ao } \\
\text { consumo }\end{array}$ & $\begin{array}{l}\text { Exame de fezes } \\
\text { especifico para o } \\
\text { parasita. Pode ser } \\
\text { necessáio examinar } \\
\text { a água ou alimentos }\end{array}$ & $\begin{array}{l}\text { Cuidado de suponte. } \\
\text { auto limitante. Se o } \\
\text { caso for severo. } \\
\text { considerar o uso de } \\
\text { paromomeina por } 7 \\
\text { dias. Para cnanças } \\
\text { de } 1 \text { a } 11 \text { anos. } \\
\text { considerar } \\
\text { utazoxande por } 3 \\
\text { dias }\end{array}$ \\
\hline $\begin{array}{l}\text { Clospora } \\
\text { cavetanensis }\end{array}$ & $\begin{array}{l}1-14 \text { dias. } \\
\text { geraimente ao } \\
\text { menos uma semana }\end{array}$ & $\begin{array}{l}\text { Diarreia } \\
\text { (geraimente } \\
\text { aquosa), perda de } \\
\text { apeute. perda } \\
\text { substancial de } \\
\text { massa corpórea } \\
\text { cãibras estomacais, } \\
\text { náusea, vômitos e } \\
\text { fatiga }\end{array}$ & $\begin{array}{l}\text { Pode diminut e } \\
\text { rencidir por } \\
\text { semanas e ate } \\
\text { meses }\end{array}$ & $\begin{array}{l}\text { Vanedades de } \\
\text { produtos trescos } \\
\text { (horifrut) }\end{array}$ & $\begin{array}{l}\text { Exame de fezes } \\
\text { especifico para o } \\
\text { parasita. Pode ser } \\
\text { necessano examinar } \\
\text { a água ou alimentos }\end{array}$ & $\begin{array}{l}\text { DMP-SMEY por } 7 \\
\text { dias }\end{array}$ \\
\hline $\begin{array}{l}\text { Entamocba } \\
\text { histolitica }\end{array}$ & $\begin{array}{l}2-3 \text { dias a } 1-4 \\
\text { semanas }\end{array}$ & $\begin{array}{l}\text { Diarreia } \\
\text { (geraimente } \\
\text { sangunolenta) } \\
\text { penstalusmo } \\
\text { frequente, dor } \\
\text { abdominal inferior }\end{array}$ & $\begin{array}{l}\text { pode ser } \\
\text { prolongado (de } \\
\text { semanas à meses) }\end{array}$ & $\begin{array}{l}\text { qualquer alimento } \\
\text { näo cozido ou } \\
\text { contaminado por } \\
\text { um manipulador } \\
\text { com o parasta apos } \\
\text { cozimento. agua } \\
\text { destinada ao } \\
\text { consumo. }\end{array}$ & $\begin{array}{l}\text { Exame de fezes } \\
\text { para cistos e } \\
\text { parasitas-podem } \\
\text { ser necussarias trés } \\
\text { amostras. Sorologa } \\
\text { para infecóes } \\
\text { crónicas }\end{array}$ & $\begin{array}{l}\text { metronidazole e um } \\
\text { agente luminal } \\
\text { (1odoquinol ou } \\
\text { paromomicuna) }\end{array}$ \\
\hline Giardia lambisa & 1.2 semanas & $\begin{array}{l}\text { Diarreia, cäibras } \\
\text { estomacais. } \\
\text { metoonsmo }\end{array}$ & dias a semanas & $\begin{array}{l}\text { qualquer alimento } \\
\text { mal cozdo ou } \\
\text { alimentos } \\
\text { contaminados por } \\
\text { mampuladores } \\
\text { infectados apos } \\
\text { cozimento, agua } \\
\text { destinada ao } \\
\text { consumo }\end{array}$ & $\begin{array}{l}\text { exame de fezes para } \\
\text { pesquisa de } \\
\text { parastas e ovos- } \\
\text { pode ser necessano } \\
\text { ao menos trés } \\
\text { amostras }\end{array}$ & metronidazole \\
\hline
\end{tabular}


Anexo 6. Aspectos Clínicos e Epidemiológicos Relacionados aos Principais Agentes Envolvidos nas DTA (cont.)

\begin{tabular}{|c|c|c|c|c|c|c|}
\hline Etiologia & $\begin{array}{l}\text { Periodo de } \\
\text { incubacia }\end{array}$ & Sinais e Sintomas & $\begin{array}{l}\text { Duracio da } \\
\text { doenca }\end{array}$ & $\begin{array}{l}\text { Alimentos } \\
\text { associados }\end{array}$ & $\begin{array}{l}\text { Testes } \\
\text { laboratoriais }\end{array}$ & Tratamento \\
\hline $\begin{array}{l}\text { Parasitas (cont) } \\
\text { Toxomplamose } \\
\text { gondil }\end{array}$ & 5.23 dias & $\begin{array}{l}\text { geralmente } \\
\text { assintomatico, } 20 \% \\
\text { pode desenvolver } \\
\text { limfoadenopatia } \\
\text { cervical ejou } \\
\text { apresentar sintomas } \\
\text { semelhantes a uma } \\
\text { gripe Em pacientes } \\
\text { imunodeprimidos: } \\
\text { doenças do sistema } \\
\text { nervoso central. } \\
\text { miocardite ou } \\
\text { pneumonia são } \\
\text { sintomas } \\
\text { geralmente } \\
\text { freqüentes. }\end{array}$ & Meses & $\begin{array}{l}\text { ingestao acidental } \\
\text { de alimentos } \\
\text { contaminados (ex } \\
\text { frutas e vegetais } \\
\text { cultivados em solo } \\
\text { contaminado com } \\
\text { fezes de gato) came } \\
\text { parcialmente cozda } \\
\text { ou crua (suina } \\
\text { cordeiro, came de } \\
\text { veado) }\end{array}$ & 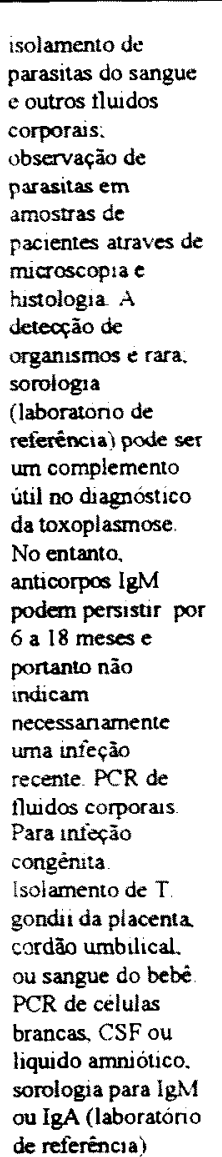 & $\begin{array}{l}\text { Infectados } \\
\text { assintomáticos não } \\
\text { procuram serviço } \\
\text { medico. Espiramicin } \\
\text { a ou sulfadiazina + } \\
\text { pirimetamina } \\
\text { podem ser } \\
\text { utilizados em } \\
\text { gravidas. } \\
\text { Primetamina } \\
\text { combinada com } \\
\text { sulfadiazna pode } \\
\text { ser utilizado para } \\
\text { undividuos } \\
\text { imunocomprometıd } \\
\text { os, em casos } \\
\text { especificos. } \\
\text { Pirimetamina } \\
\text { combinada a } \\
\text { sulfadiazina (com } \\
\text { ou sem esteroides) } \\
\text { podem ser } \\
\text { ministradas em } \\
\text { doenças oculares } \\
\text { quando indicado. } \\
\text { Acido folinico è } \\
\text { ministrado com } \\
\text { pritamina } \\
\text { combinada a } \\
\text { sulfadiazina para } \\
\text { neutralizar a } \\
\text { supressão da } \\
\text { medula óscea }\end{array}$ \\
\hline $\begin{array}{l}\text { Toxomplasma } \\
\text { gondi (infeçäo } \\
\text { congenta) }\end{array}$ & Em recém nascidos & $\begin{array}{l}\text { O tratamento da } \\
\text { mäe pode reduar a } \\
\text { severidade e a } \\
\text { incidéncia da } \\
\text { infeçāo congénta. } \\
\text { A maiona das } \\
\text { crianças infectadas } \\
\text { apresentam poucos } \\
\text { sintomas ao nascer. } \\
\text { Posteriormente } \\
\text { geralmente } \\
\text { desenvolvem sinas } \\
\text { de toxoplasmose } \\
\text { congénita (retardo } \\
\text { mental. } \\
\text { detenoração severa } \\
\text { da visão. ataques) a } \\
\text { menos que a } \\
\text { infeçäo seja tratada }\end{array}$ & Meses & $\begin{array}{l}\text { Transmiss } 30 \text { de } \\
\text { mäe (adquinu } \\
\text { infeça aguda } \\
\text { durante a gravidez) } \\
\text { para filho }\end{array}$ & & \\
\hline Techinella spiralis & $\begin{array}{l}\text { [-2 dias para } 0 \\
\text { inicio dos sintomas. } \\
\text { outras iniciam-se de } \\
2 \text { a } 8 \text { semanas } \\
\text { depois da infeção }\end{array}$ & $\begin{array}{l}\text { Agudo nausea } \\
\text { diarteia vómnos. } \\
\text { fatiga, febre. } \\
\text { desconfono } \\
\text { abdominal } \\
\text { acompanhado dores } \\
\text { musculares, } \\
\text { fraqueza e } \\
\text { complicaçóes } \\
\text { ocastonals cardíacas } \\
\text { e neurológicas }\end{array}$ & Meses & $\begin{array}{l}\text { Came crua ou mal } \\
\text { cozida } \\
\text { contaminada } \\
\text { geralmente porco } \\
\text { além de ursos e } \\
\text { alces }\end{array}$ & $\begin{array}{l}\text { Sorologia positiva } \\
\text { ou demostraça de } \\
\text { larva via biopsia } \\
\text { muscular Aumento } \\
\text { de eosinofilos }\end{array}$ & $\begin{array}{l}\text { Cuidado de suporte } \\
\text { combinado com } \\
\text { mebendazole ou } \\
\text { abendazole }\end{array}$ \\
\hline
\end{tabular}


Anexo 6. Aspectos Clínicos e Epidemiológicos Relacionados aos Principais Agentes Envolvidos nas DTA (cont.)

\begin{tabular}{|c|c|c|c|c|c|c|}
\hline Etiologia & $\begin{array}{l}\text { Periodo de } \\
\text { incubacito }\end{array}$ & Sinais e Sintomns & $\begin{array}{l}\text { Duracio da } \\
\text { doenca }\end{array}$ & $\begin{array}{l}\text { Alimentos } \\
\text { associados }\end{array}$ & $\begin{array}{l}\text { Testes } \\
\text { laboratoriais }\end{array}$ & Tratamento \\
\hline \multicolumn{7}{|l|}{ Agente } \\
\hline \multicolumn{7}{|l|}{ s nko infecciosos } \\
\hline Antimonio & $\begin{array}{l}5 \text { min a } 8 \text { horas } \\
\text { normaimente em } \\
\text { menos de uma hora }\end{array}$ & $\begin{array}{l}\text { Vômitos. sabor } \\
\text { metálico }\end{array}$ & $\begin{array}{l}\text { Geralmente auto- } \\
\text { limitado }\end{array}$ & $\begin{array}{l}\text { Recipientes } \\
\text { metálicos }\end{array}$ & $\begin{array}{l}\text { Identificação do } \\
\text { metal em bebidas } \\
\text { ou alimentos }\end{array}$ & Cuidado de suport \\
\hline Arsènico & Poucas horas & $\begin{array}{l}\text { Vômitos, colicas e } \\
\text { diarreia }\end{array}$ & Alguns dias & $\begin{array}{l}\text { Alimentos } \\
\text { contaminados }\end{array}$ & $\begin{array}{l}\text { Urina Pode causar } \\
\text { eosinofilia }\end{array}$ & $\begin{array}{l}\text { Lavagem gastrica. } \\
\text { BAL (dimercaprol) }\end{array}$ \\
\hline Cadmio & $\begin{array}{l}5 \text { min a } 8 \text { horas } \\
\text { geralmente menos } \\
\text { de uma hora }\end{array}$ & $\begin{array}{l}\text { Náusea vòmitos. } \\
\text { mialgia, aumento na } \\
\text { salivaçajo, dor } \\
\text { estomacal }\end{array}$ & $\begin{array}{l}\text { Geralmente auto } \\
\text { IImitante }\end{array}$ & $\begin{array}{l}\text { Frutos do mar. } \\
\text { ostras, moluscos. } \\
\text { lagosta grãos. } \\
\text { amendoim }\end{array}$ & $\begin{array}{l}\text { ldentunicaçao do } \\
\text { metal nos alimentos }\end{array}$ & Cuidado de supone \\
\hline \multirow[t]{3}{*}{$\begin{array}{l}\text { Envenenamento por } \\
\text { Ciguatera (toxma) }\end{array}$} & 2.6 horas & $\begin{array}{l}\text { Gl: dor abdominal. } \\
\text { nausea, vomitos e } \\
\text { diarreia }\end{array}$ & $\begin{array}{l}\text { Dias. semanas ou } \\
\text { meses }\end{array}$ & $\begin{array}{l}\text { Variedade de peixes } \\
\text { de recife. Grouper, } \\
\text { red snapper, } \\
\text { amberjack e } \\
\text { barracuda (mais } \\
\text { comuns) }\end{array}$ & $\begin{array}{l}\text { Radioassay para } \\
\text { toxina em peixes ou } \\
\text { uma histona } \\
\text { plausivel de } \\
\text { exposicáo }\end{array}$ & $\begin{array}{l}\text { Cudado de suports. } \\
\text { mantol 1Y: as } \\
\text { cnanaças sajo mass } \\
\text { vuineravets. }\end{array}$ \\
\hline & 3 horas & $\begin{array}{l}\text { Neurológicos: } \\
\text { parestesias, } \\
\text { alternância de frios } \\
\text { e calorex. dor. } \\
\text { fraqueza }\end{array}$ & & & & \\
\hline & 2.5 dias & $\begin{array}{l}\text { Cardiovascular: } \\
\text { bradicardia } \\
\text { hipotensajo. } \\
\text { aumento da } \\
\text { anormalidades na } \\
\text { faixa de onda T }\end{array}$ & & & & \\
\hline Sher & $\begin{array}{l}5 \text { min a } 8 \text { horas } \\
\text { geralmente menos } \\
\text { de uma hora }\end{array}$ & $\begin{array}{l}\text { Vausea vömitos, } \\
\text { vómito azul ou } \\
\text { vermeiho }\end{array}$ & $\begin{array}{l}\text { Geraimente auto } \\
\text { limutante }\end{array}$ & $\begin{array}{l}\text { Recipientes } \\
\text { metalicos }\end{array}$ & $\begin{array}{l}\text { Identificaçăo do } \\
\text { metal em bebidas } \\
\text { ou alimentos }\end{array}$ & Cuidado de supone \\
\hline Mercuno & $\begin{array}{l}\text { Uma semana ou } \\
\text { mais }\end{array}$ & $\begin{array}{l}\text { Dormència } \\
\text { fraqueza de } \\
\text { membros infenores. } \\
\text { paralisias motoras, } \\
\text { visäo prejudicada, } \\
\text { cegueira e coma. } \\
\text { Mulheres grávidas e } \\
\text { fetos em } \\
\text { desenvolvimento } \\
\text { constutuem-se } \\
\text { grupos vilneräveis }\end{array}$ & Pode ser duradouro & $\begin{array}{l}\text { Peixes expostos a } \\
\text { mercúno orgänco, } \\
\text { gräos tratados com } \\
\text { fungicidas contendo } \\
\text { mercúno }\end{array}$ & $\begin{array}{l}\text { Analise de sangue e } \\
\text { cabelo }\end{array}$ & Cuidado de suporte \\
\hline $\begin{array}{l}\text { Toxinas de } \\
\text { cogumelos de curta } \\
\text { açäo (museinol. } \\
\text { muscanna. } \\
\text { psilocibina copnus } \\
\text { artemetans acido } \\
\text { ibotenico) }\end{array}$ & $<$ duns horas & $\begin{array}{l}\text { Vômitos, diartéia } \\
\text { confusasa, distübio } \\
\text { visual, salivação. } \\
\text { diaforesis. } \\
\text { alucinaçóes. } \\
\text { reapōes semelhantes } \\
\text { ao disulfiram. } \\
\text { distúrbio visual }\end{array}$ & Auto limutante & $\begin{array}{l}\text { Cogumelos } \\
\text { selvagens (a cocçðo } \\
\text { pode nảo destruir } \\
\text { essas toxinas) }\end{array}$ & $\begin{array}{l}\text { Síndrame típica e } \\
\text { identificaçäo de } \\
\text { cogumelos, ou } \\
\text { demonstracảo da } \\
\text { toxina }\end{array}$ & Cudado de suporte \\
\hline $\begin{array}{l}\text { Toxina de } \\
\text { cogumelos de ação } \\
\text { prolongada } \\
\text { (amanutuna) }\end{array}$ & $\begin{array}{l}48 \text { horas diarreia } \\
24-48 \text { horas } \\
\text { falência hepátıca }\end{array}$ & $\begin{array}{l}\text { Diarréia cảibras } \\
\text { abdominais, } \\
\text { podendo levar a } \\
\text { falência renal ou } \\
\text { hepática }\end{array}$ & Geralmente fatal & Cogumelos & $\begin{array}{l}\text { Síndrome tipica e } \\
\text { identificação dos } \\
\text { cogumelos eiou } \\
\text { demonstração da } \\
\text { toxina }\end{array}$ & $\begin{array}{l}\text { Cuidado de suporte. } \\
\text { life threatening. } \\
\text { may need life } \\
\text { support }\end{array}$ \\
\hline $\begin{array}{l}\text { Envenenamento por } \\
\text { nutrto }\end{array}$ & 1.2 horas & $\begin{array}{l}\text { Náusea vómitos } \\
\text { cianose. dor de } \\
\text { cabeça, lontura. } \\
\text { fraqueza, perda de } \\
\text { conscréncia sangue } \\
\text { cor marrom } \\
\text { chocolate }\end{array}$ & $\begin{array}{l}\text { Geralmente auto } \\
\text { limintante }\end{array}$ & $\begin{array}{l}\text { Carnes curadas, } \\
\text { qualquer alimento } \\
\text { contaminado. } \\
\text { espinafre exposto a } \\
\text { nituificaçào } \\
\text { excessiva }\end{array}$ & $\begin{array}{l}\text { Análise de } \\
\text { alimentos e sangue }\end{array}$ & $\begin{array}{l}\text { Cuidado de supone, } \\
\text { azul metileno }\end{array}$ \\
\hline $\begin{array}{l}\text { Pestucidas } \\
\text { nrganolostatos ou } \\
\text { carbamates) }\end{array}$ & $\begin{array}{l}\text { de minutos a } \\
\text { poucas horas }\end{array}$ & $\begin{array}{l}\text { Náuseas, vôrntos. } \\
\text { cäibras abdominais. } \\
\text { diarreı. dor de } \\
\text { cabeça, nervosismo. } \\
\text { visão obscurecida. } \\
\text { contraçöes } \\
\text { nervosas. } \\
\text { convulsöes. } \\
\text { salivaçäo e meısis }\end{array}$ & $\begin{array}{l}\text { geralmente auto } \\
\text { limitada }\end{array}$ & $\begin{array}{l}\text { quaiquer alimento } \\
\text { contaminado }\end{array}$ & $\begin{array}{l}\text { Analise de alimento } \\
\text { e sangue }\end{array}$ & $\begin{array}{l}\text { Atropina. 2-PAM } \\
\text { (pralidoxime) e } \\
\text { unlizado quando } \\
\text { atropina e } \\
\text { ineficiente no } \\
\text { controle dos } \\
\text { sintomas e e } \\
\text { raramente } \\
\text { necessário em } \\
\text { envenenamentos } \\
\text { por carbamate }\end{array}$ \\
\hline
\end{tabular}


Anexo 6. Aspectos Clínicos e Epidemiológicos Relacionados aos Principais Agentes Envolvidos nas DTA (cont.)

\begin{tabular}{|c|c|c|c|c|c|c|}
\hline Etiologia & $\begin{array}{l}\text { Periodo de } \\
\text { incubacióo }\end{array}$ & Sinais e Sintomas & $\begin{array}{l}\text { Duraçio da } \\
\text { doença }\end{array}$ & $\begin{array}{l}\text { Alimentos } \\
\text { associados }\end{array}$ & $\begin{array}{l}\text { Testes } \\
\text { laboratoriais }\end{array}$ & Tratamento \\
\hline \multicolumn{7}{|l|}{$\begin{array}{l}\text { Agentes nio } \\
\text { infocciosos (cont) }\end{array}$} \\
\hline $\begin{array}{l}\text { Puffer lish } \\
\text { (tetrodotoxina) }\end{array}$ & $<30 \mathrm{~min}$ & $\begin{array}{l}\text { Parastesias. } \\
\text { vômitos, diarreia } \\
\text { dor abdominal. } \\
\text { paralisia } \\
\text { ascendente. falência } \\
\text { respiratóna }\end{array}$ & $\begin{array}{l}\text { óbito normalmente } \\
\text { de } 4 \text { a } 6 \text { horas }\end{array}$ & Puffer fish & $\begin{array}{l}\text { detecção de } \\
\text { tetrodoxina no } \\
\text { peixe }\end{array}$ & $\begin{array}{l}\text { Life-threatening. } \\
\text { pode necessitar do } \\
\text { suporte respiratorio }\end{array}$ \\
\hline $\begin{array}{l}\text { scombroid } \\
\text { (histamina) }\end{array}$ & 1 min a 3 horas & $\begin{array}{l}\text { excitação, irritação } \\
\text { da pele, sensação de } \\
\text { queimação na pele, } \\
\text { boca e garganta. } \\
\text { vertigem, uricária. } \\
\text { parastesias }\end{array}$ & 3 a 6 horas & $\begin{array}{l}\text { Peixe: bluefin, } \\
\text { atum, skipjack, } \\
\text { mackerel, marlin. } \\
\text { escolar e mahi mahu }\end{array}$ & $\begin{array}{l}\text { Demonstração da } \\
\text { histamina em } \\
\text { alimentos ou } \\
\text { diagnóstico clinico }\end{array}$ & $\begin{array}{l}\text { Cuidado de supone. } \\
\text { atihistaminco }\end{array}$ \\
\hline \multirow[t]{3}{*}{$\begin{array}{l}\text { Toxinas de frutos } \\
\text { do mar (mariscos e } \\
\text { crustaceos). } \\
\text { Toxinas diartéicas. } \\
\text { neurotoxicas e } \\
\text { amnesic }\end{array}$} & $\begin{array}{l}\text { Diarreia por } \\
\text { envenenamento por } \\
\text { mariscos (DSP) - } \\
\text { de } 30 \text { min a } 2 \text { horas }\end{array}$ & $\begin{array}{l}\text { Náusea, vómitos, } \\
\text { diartéia e dor } \\
\text { abdominal } \\
\text { acompanhada por } \\
\text { sensação de frio, } \\
\text { dor de cabeça e } \\
\text { febre }\end{array}$ & $\begin{array}{l}\text { De horas a } 2 \text { a } 3 \\
\text { dias }\end{array}$ & $\begin{array}{l}\text { Uma variedade de } \\
\text { frutos do mar, } \\
\text { principalmente } \\
\text { mexilhöes, ostras, } \\
\text { concha de vienra } \\
\text { (scallops) e frutos } \\
\text { do mar } \\
\text { provenientes da } \\
\text { costa da california e } \\
\text { do Golfo do Mexico }\end{array}$ & $\begin{array}{l}\text { Detecão da toxina } \\
\text { em frutos do mar. } \\
\text { cromatografia de } \\
\text { liquido em pressão } \\
\text { elevada }\end{array}$ & $\begin{array}{l}\text { Cuidado de suporte. } \\
\text { geralmente auto } \\
\text { limitante. Idosos } \\
\text { sảo geraimente } \\
\text { mais sensiveis ao } \\
\text { ASP }\end{array}$ \\
\hline & $\begin{array}{l}\text { Veurotoxucidade } \\
\text { por envenentamento } \\
\text { por frutos do mar } \\
\text { (NSP) - de poucas } \\
\text { minutoas a horas }\end{array}$ & $\begin{array}{l}\text { Ardor e dormência } \\
\text { dos labios. lingua e } \\
\text { garganta. dores } \\
\text { musculares. tontura. } \\
\text { sensaçōes de calor e } \\
\text { frio alternadas. } \\
\text { diarréia e vömitos }\end{array}$ & & & & \\
\hline & $\begin{array}{l}\text { Amnesic shellfish } \\
\text { poisoning (ASP) - } \\
24-48 \text { horas }\end{array}$ & $\begin{array}{l}\text { Vômitos, diarréia, } \\
\text { dor abdominal e } \\
\text { problemas } \\
\text { neurológicos como } \\
\text { confusäo, perda de } \\
\text { memória } \\
\text { desorientação, } \\
\text { ataques, coma }\end{array}$ & & & & \\
\hline $\begin{array}{l}\text { Toxinas de frutos } \\
\text { do mar (paraliticas) }\end{array}$ & De 30 min a 3 horas & $\begin{array}{l}\text { Diarréia náuseas, } \\
\text { vômitos evoluindo } \\
\text { a parastesias da } \\
\text { boca, lábios, } \\
\text { fraqueza, disfasia } \\
\text { disfonia, paralisia } \\
\text { respiratoria }\end{array}$ & Dias & $\begin{array}{l}\text { Scallops, } \\
\text { mexilhöes, } \\
\text { moluscos, berbigão }\end{array}$ & $\begin{array}{l}\text { Detecção da toxina } \\
\text { nos alimentos ou } \\
\text { água. } \\
\text { Cromatografia de } \\
\text { liquido em pressão } \\
\text { elevada }\end{array}$ & $\begin{array}{l}\text { Life-threatening, } \\
\text { pode haver } \\
\text { necessidade de } \\
\text { suporte respiratorio }\end{array}$ \\
\hline Sodium tluonde & $\begin{array}{l}\text { Poucos minutos a } \\
\text { duas horas }\end{array}$ & $\begin{array}{l}\text { Gosto de sal e } \\
\text { sabão. dorméncia } \\
\text { na boca, vômitos. } \\
\text { diarréia, dilatação } \\
\text { das pupilas, } \\
\text { espasmos, pallor. } \\
\text { choque, colapso. }\end{array}$ & $\begin{array}{l}\text { Geraimente auto } \\
\text { limitante }\end{array}$ & $\begin{array}{l}\text { Alimentos } \\
\text { desidratados (ovos, } \\
\text { leite, farinha. pó de } \\
\text { arroz para cozedura, } \\
\text { mistura para bolos) } \\
\text { contaminados corn } \\
\text { sódio fluorido - } \\
\text { presente em } \\
\text { inseticidas e } \\
\text { raticidas }\end{array}$ & $\begin{array}{l}\text { Teste de vomito ou } \\
\text { lavados gastricos. } \\
\text { Análise do } \\
\text { aliemntos }\end{array}$ & Cuidado de suporte \\
\hline Thallum & Poucas horas & $\begin{array}{l}\text { Náusea, vômitos, } \\
\text { diarréia, parathesias } \\
\text { dolorosa, } \\
\text { polineuropatia } \\
\text { motora, perda de } \\
\text { cabelo }\end{array}$ & Diversos dias & $\begin{array}{l}\text { Contaminação de } \\
\text { alimentos }\end{array}$ & Urina, cabelo & Cuidado de suporte \\
\hline $\operatorname{Tin}$ & $\begin{array}{l}5 \text { min a } 8 \text { horas } \\
\text { normalmente menos } \\
\text { de uma hora }\end{array}$ & $\begin{array}{l}\text { Nausea, vômutos e } \\
\text { diartéia }\end{array}$ & $\begin{array}{l}\text { Geralmente auto } \\
\text { limitado }\end{array}$ & $\begin{array}{l}\text { Recipientes } \\
\text { metalicos }\end{array}$ & $\begin{array}{l}\text { Análise de } \\
\text { alimentos }\end{array}$ & Cuidado de supone \\
\hline Vomutoxına & $\begin{array}{l}\text { De poucos minutos } \\
\text { a } 3 \text { horas }\end{array}$ & $\begin{array}{l}\text { Náusea dor de } \\
\text { cabeça, dor } \\
\text { abdominal, vômitos }\end{array}$ & $\begin{array}{l}\text { Geralmente auto } \\
\text { limitado }\end{array}$ & $\begin{array}{l}\text { Grãos como trigo, } \\
\text { milho e cevada }\end{array}$ & $\begin{array}{l}\text { Análise de } \\
\text { alimentos }\end{array}$ & Cuidado de suporte \\
\hline Zinco & Poucas horas & $\begin{array}{l}\text { Cãibras estomacais, } \\
\text { náusea, vômitos, } \\
\text { diarréia e mialgias }\end{array}$ & $\begin{array}{l}\text { Geralmente auto } \\
\text { limitado }\end{array}$ & $\begin{array}{l}\text { Recipientes } \\
\text { metálicos }\end{array}$ & $\begin{array}{l}\text { Análises de } \\
\text { alimentos, sangue e } \\
\text { fezes, saliva ou } \\
\text { urina }\end{array}$ & Cuidado de suporte \\
\hline
\end{tabular}

